\title{
الإعجاز العلمي في سورة الفرقان
}

\section{g أمه ر رضان}

$$
\text { أستاذ التفسير وعلوه القرآن المساعد }
$$


الإعجاز العلمي في سورة الفرقان

势

IVT

$\overline{3}$ 


$$
\text { بسم الله الرحن الرحيم }
$$

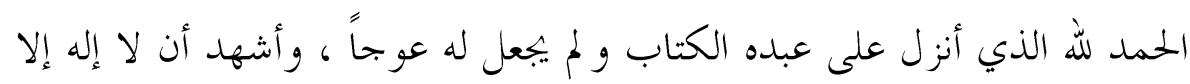

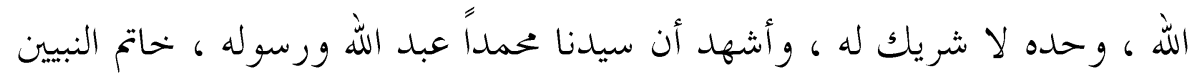

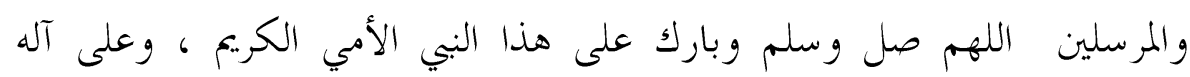

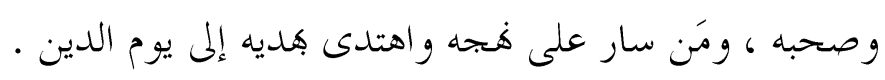

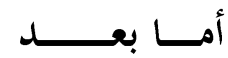

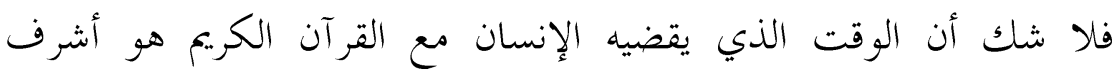

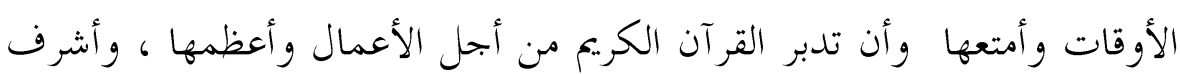

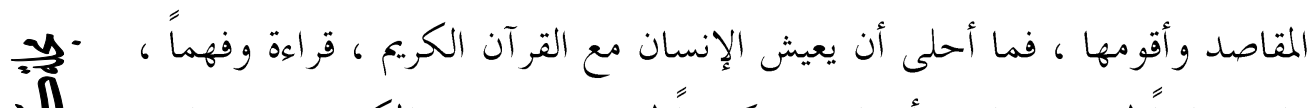

毒

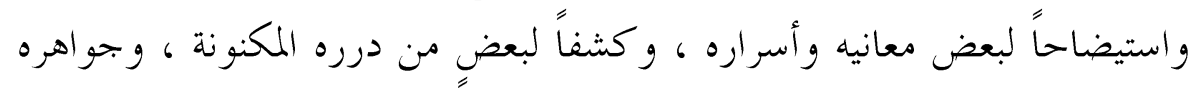

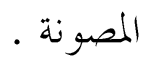
IVV

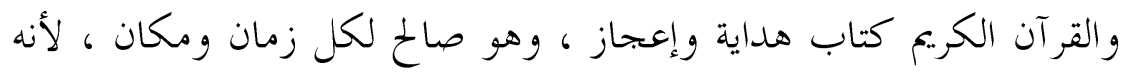

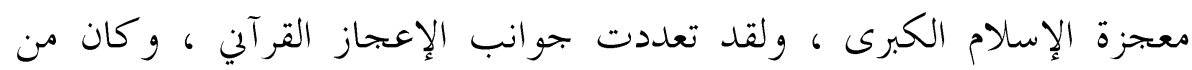

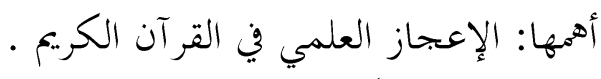

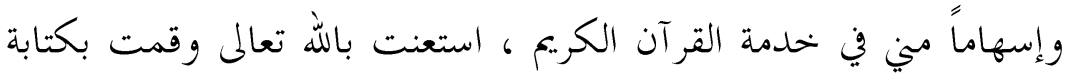

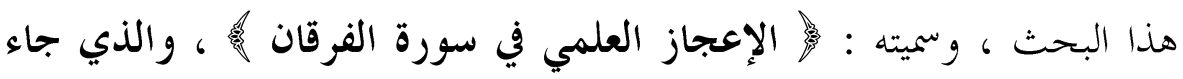

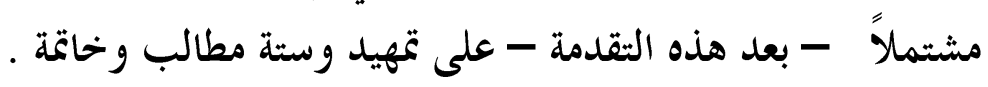

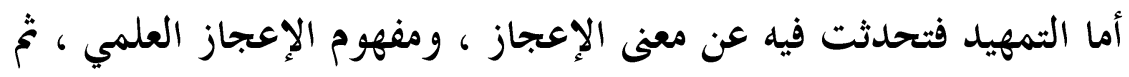

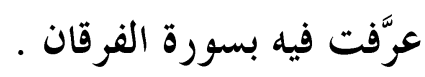

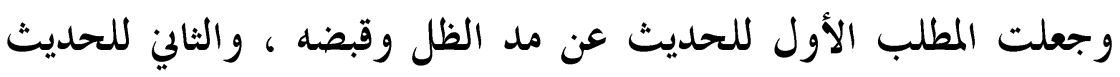

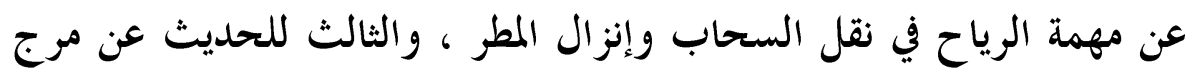

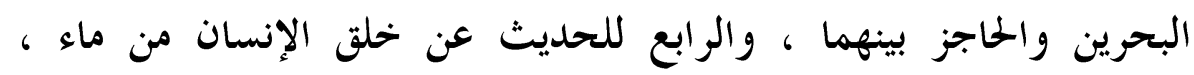

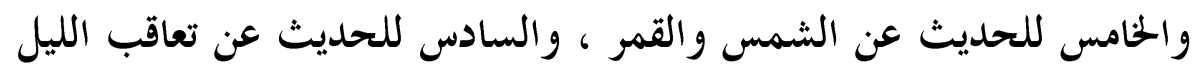

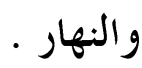

وأما الحاتمة فاشتملت على فهرس المصادر والمراجع وفهرس الموضوعات . 


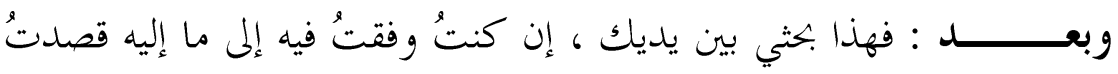

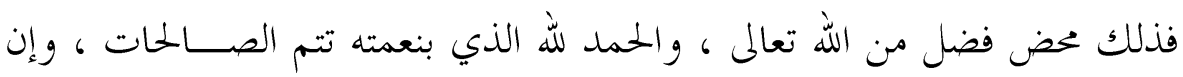

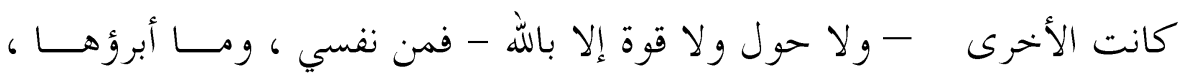

\section{鼻大落}

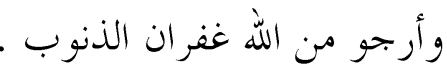

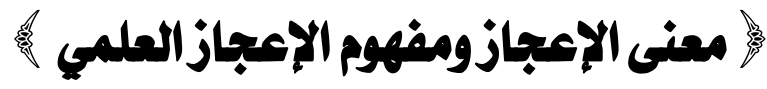 \\ معنى الإعجاز في اللغلة واستعمال القرآن :}

بالتدبر في آيات القر آن الكريم ، و بالرجوع إلى المعاجم اللغوية ، يتبين لنا أن العَجْز

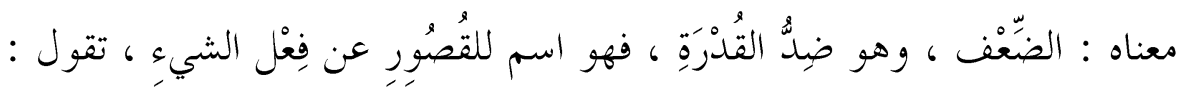

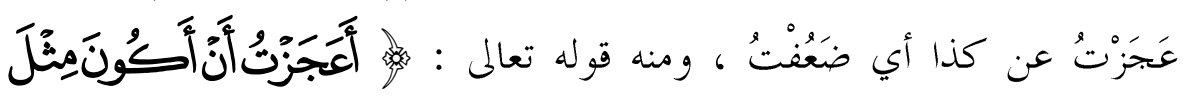

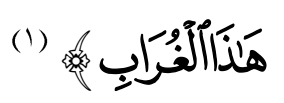

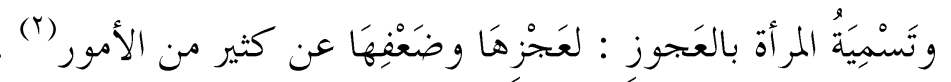

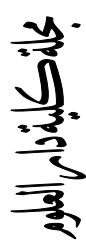

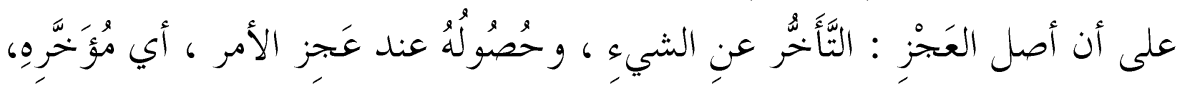

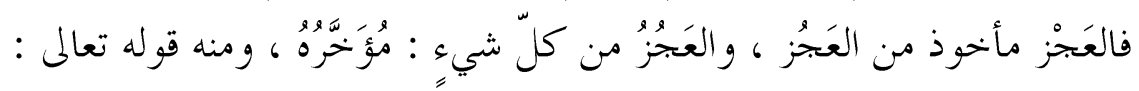

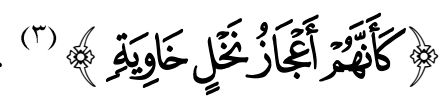
iv人

و الإعجاز معناه : الفوت والسبق والغلبة ، يقال : أعجزلي فلان ، أي فاقين

$$
\text { وغلبين وفاتين ، و أعجزه الشيء إذا فاته . }
$$

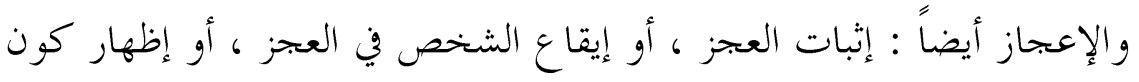

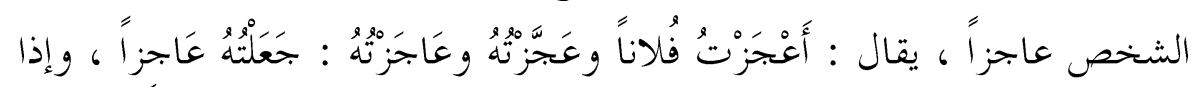
ثبت الإعجاز ظهرت قوة المُعِجْز .

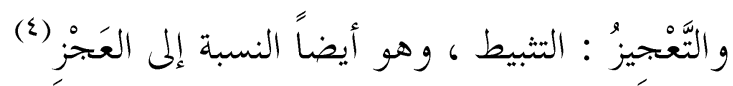


والمعجزة في اصطلاح العلماء : أمر خارق للعادة ، مقرون بالتحدي ، يُظهره

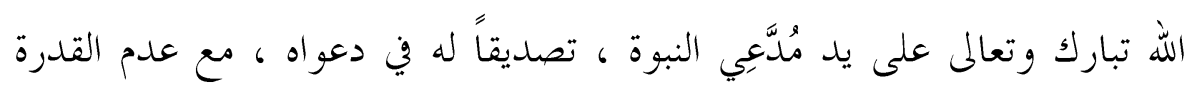
على الإتيان بمثله (0).

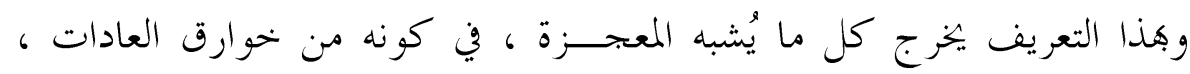

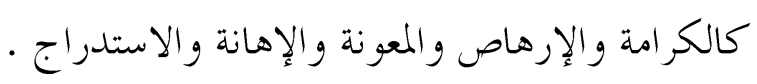

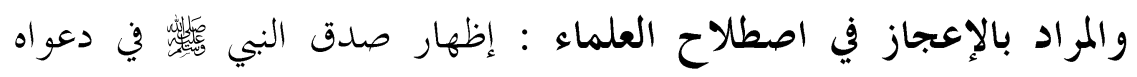

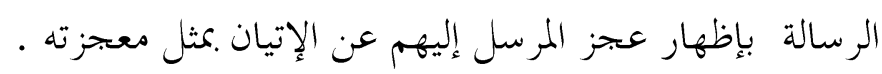

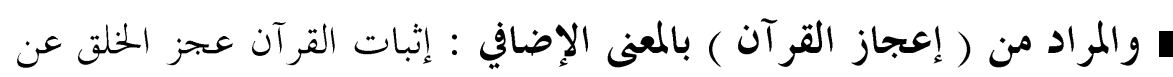

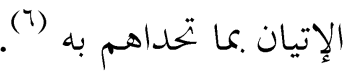

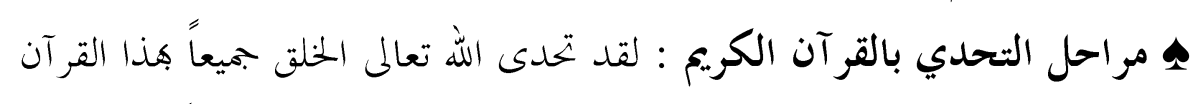

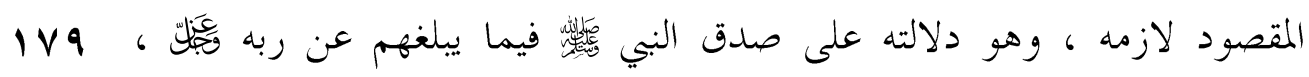

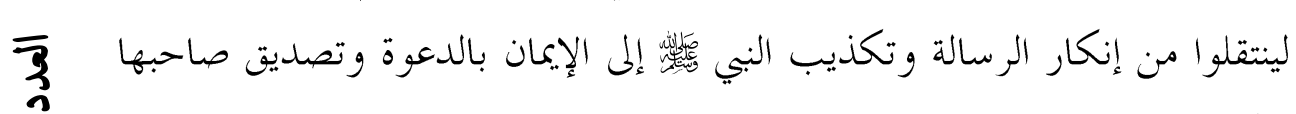
. 赔能 و ولقد تحدى الله تبارك وتعالى هؤلاء بصور شتى ، وبأساليب متنوعة ، وعلى إنى

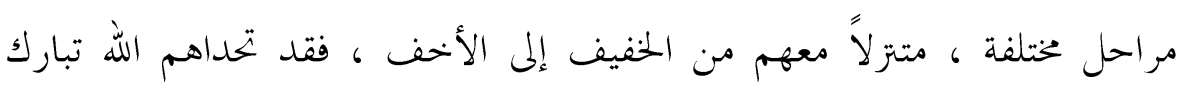

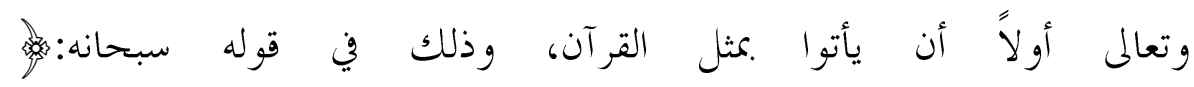

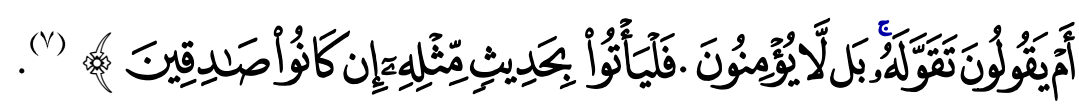

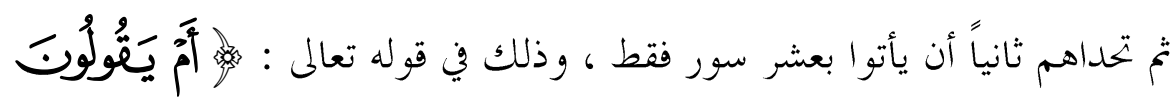

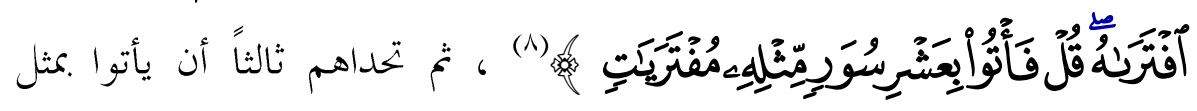

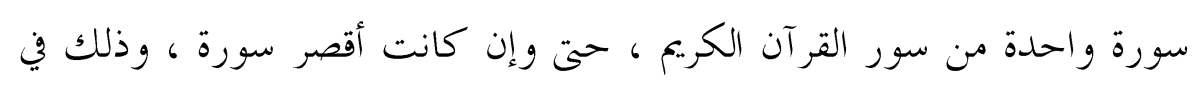

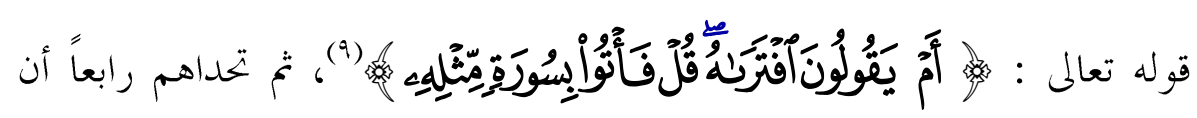


يأتوا بسورة واحدة تتماثل مع السورة القر آنية ولو مماثلة جزئية ، أي تتشابه معها

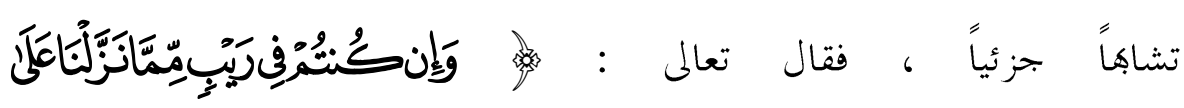

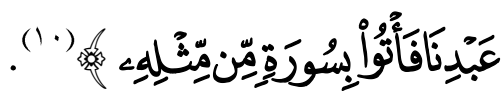

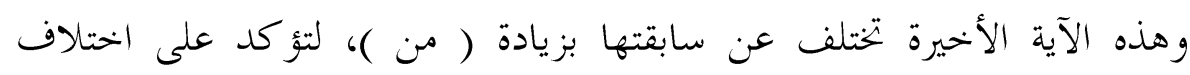

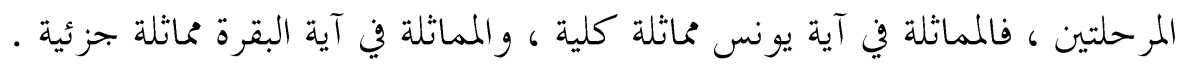

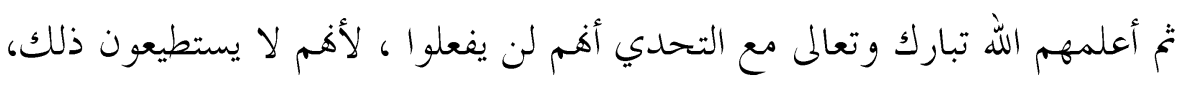

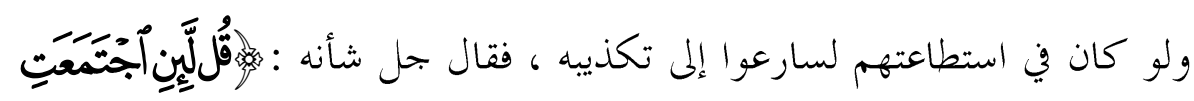

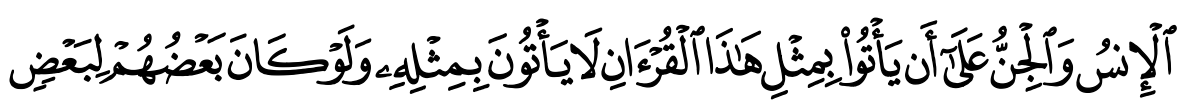

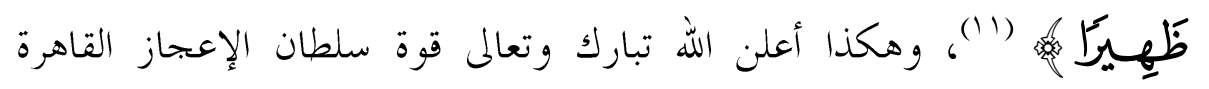

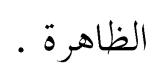

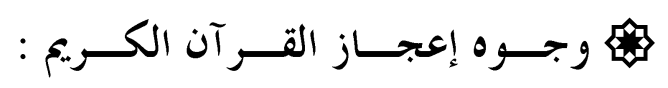

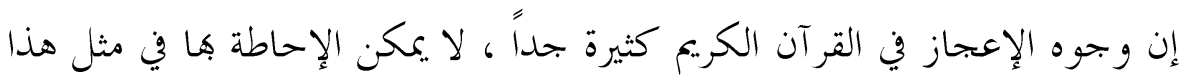

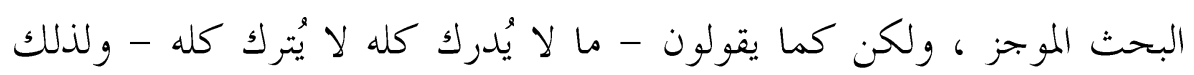

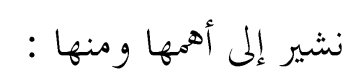

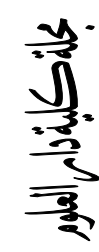

$1 \wedge$.

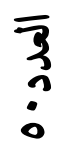

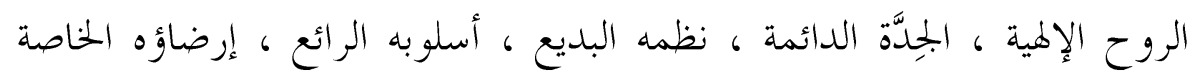

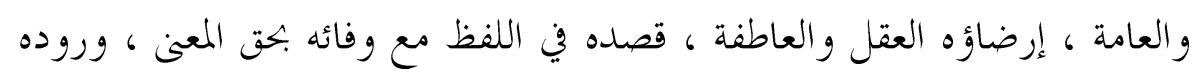

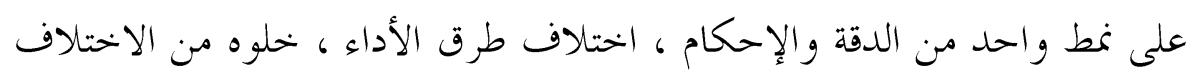

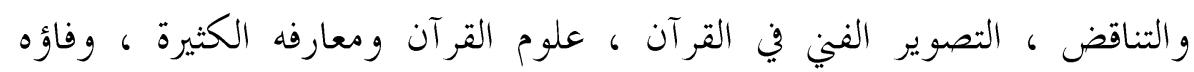

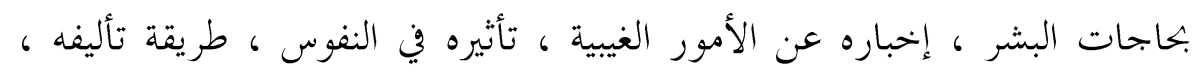

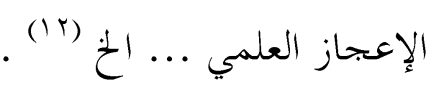

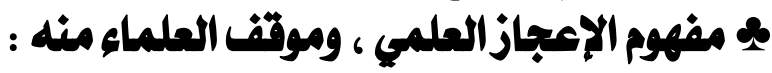

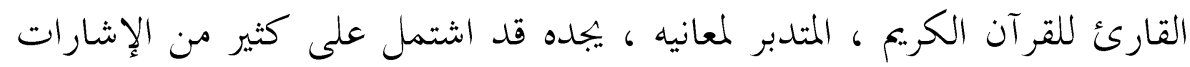

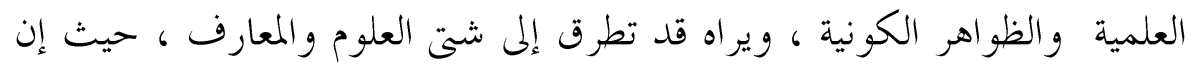




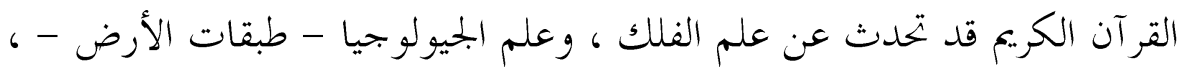

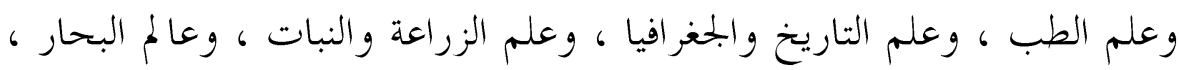

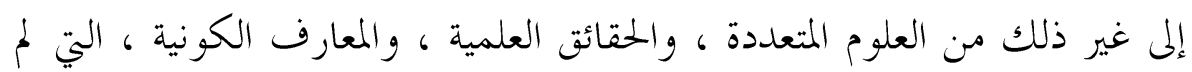

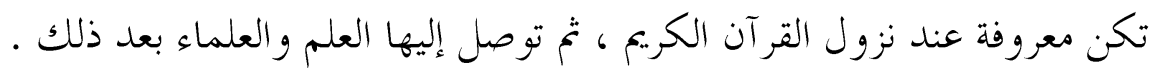

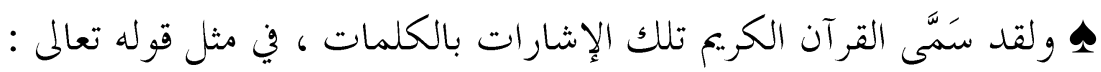

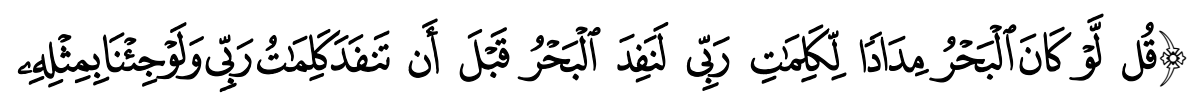

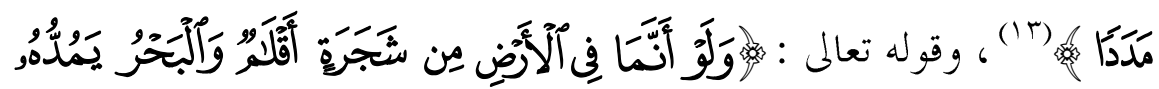

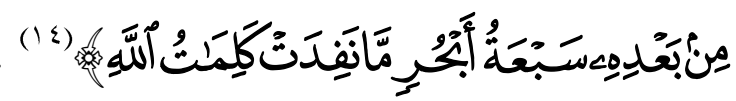

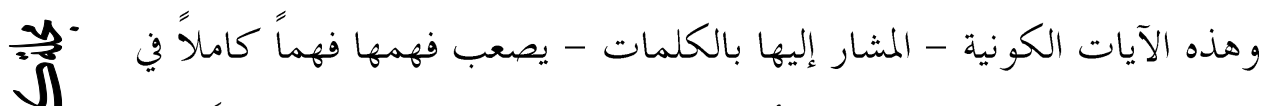

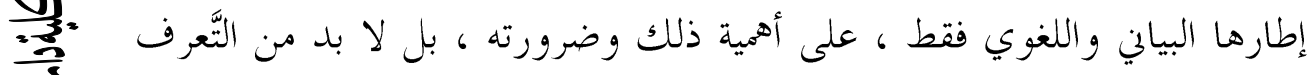

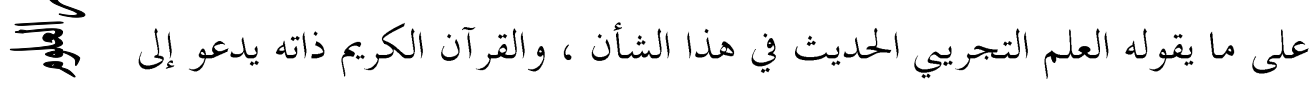
$1 \wedge 1$

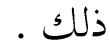

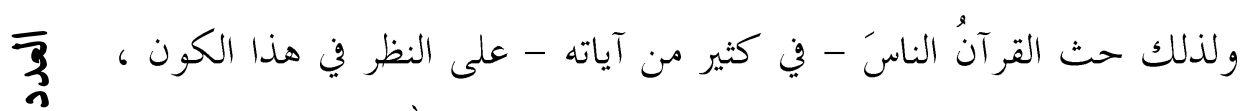

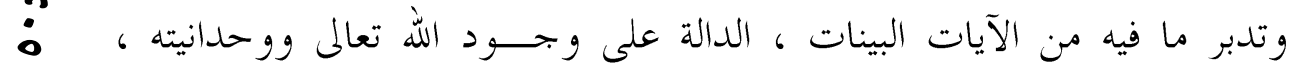

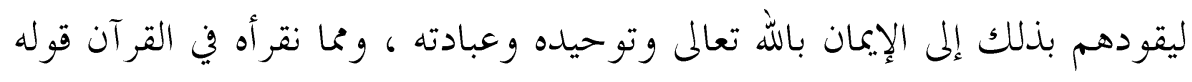
تعالى :

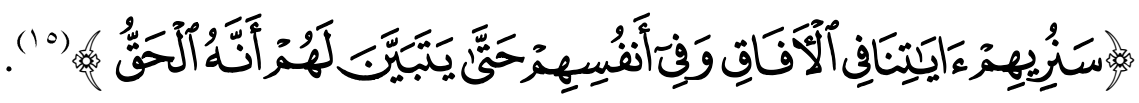

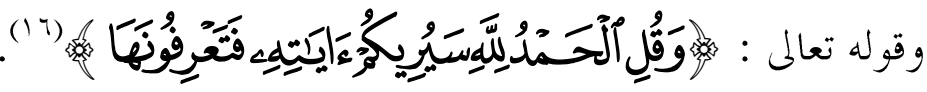

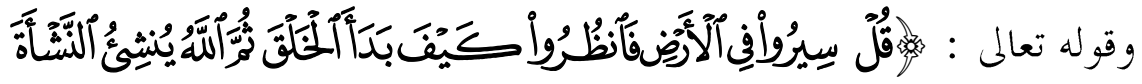

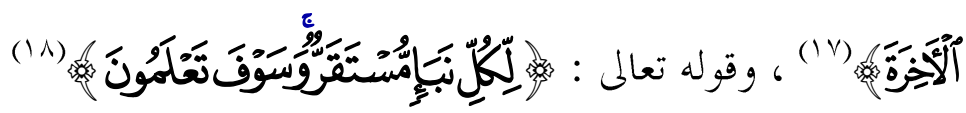

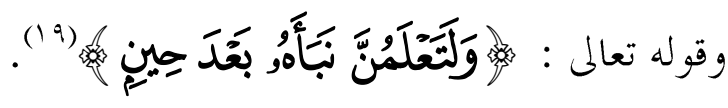


هذه الآيات - ونخوها - يمكن اعتبارها أساساً وأصلاً لإعجاز العلمي في

القرآن الكريم ، و كأنّا الله تباركك وتعالى يدعونا في تلك الآيات إلى الاكتشافات العلمية ، و الوصول إلى العلم التجريي النافع ، و وي كل يوم يكشف لنا العلم

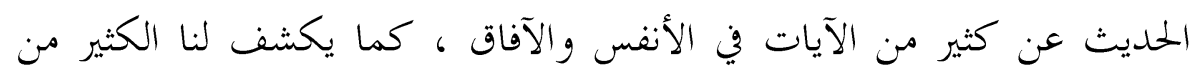

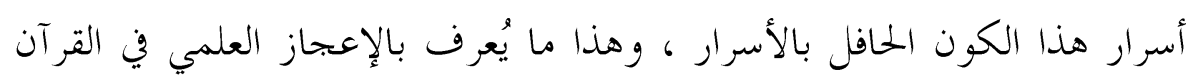
الكريم

مه تعريف الإعجاز العلمي في القر آن الكريم :

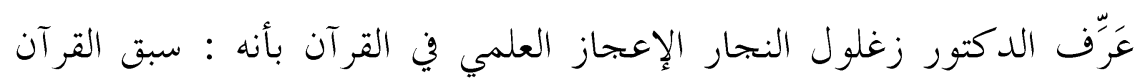

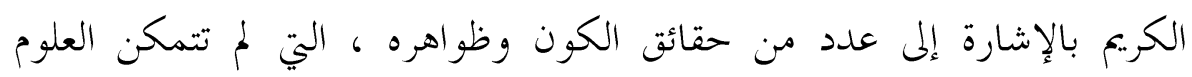

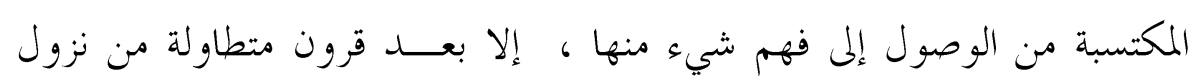

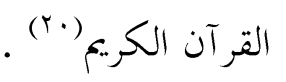
ويمكن أن يُعَّف الإعجاز العلمي في القر آن بأنه :

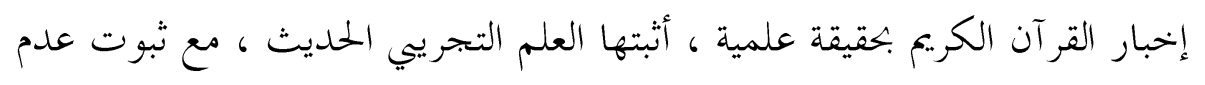

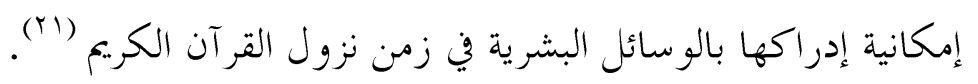
: الفرق 氛 IAr $\overline{3}$
$\vdots$

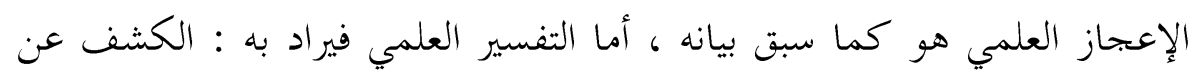
معاني الآية في ضوء ما ترجحت صحته من نظريات العلوم الكونية (Trان.

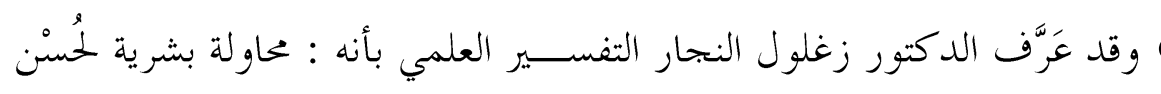

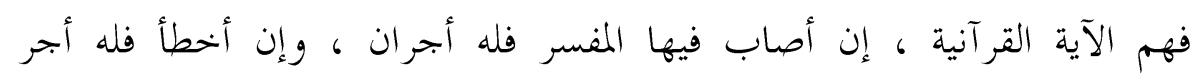
واحد) (rT)

وباختصار : يُمْكِن أن يُفَرَّق بين الإعجاز العلمي والتفسير العلمي في نقاط من : أ ا- الإعجاز العلمي قطعيّ الدلالة ، أما التفسير العلمي فظيّ الدلالة . 


\section{الإعجاز العلمي في سورة الفرقان}

Y- التفسير العلمي أعم من الإعجاز العلمي ، إذ إن كل إعجاز علمي هو من

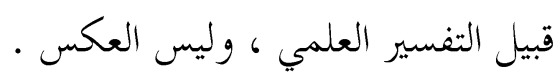

ب- الإعجاز العلمي متفق عليه بين العلماء ، أما التفسير العلمي فمختلف فيه ، بل إن من العلماء مَن ينكره ولا يجيزه ، كما سيأتي بيانه قريباً .

ع- وقوع الخطأ في الإعجاز العلمي قليل ونادر ، أما التفسير العلمي فوقوع الخطأ فيه أكثر

على أن الخطأ في الإعجاز العلمي - إذا وقــع - فغالباً ما يقع بسبب عــــم الربط بين الحقيقة الشرعية والحقيقة الكونية ، أما الخطأ في التفسير العلمي فيقع

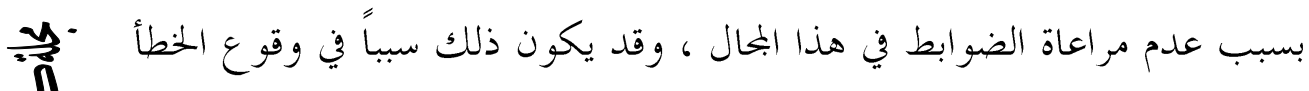
في فهم كتاب الله تعالى ، ولذلك انخرف كثير من الباحثين المعاصرين عن جادة

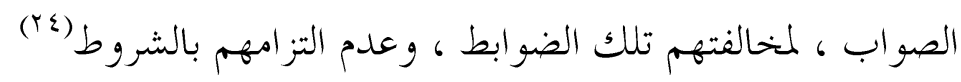

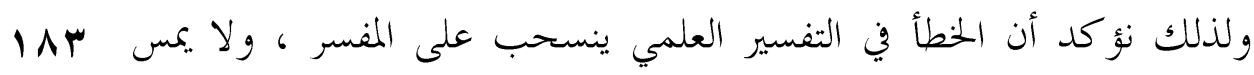

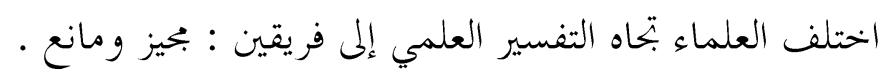
ففريق يؤيد هذا اللون من التفسير ، ويجيزه ، بل ويلدياه

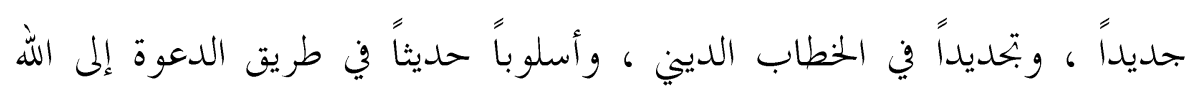
تعالى، وهداية الناس إلى دين الله ، .منهج جديد يتو افق مع العصر الحاضر ، وهؤلاء

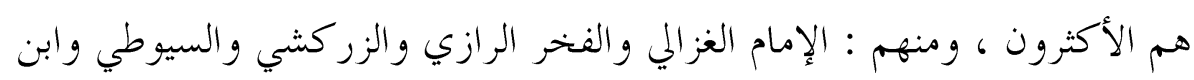

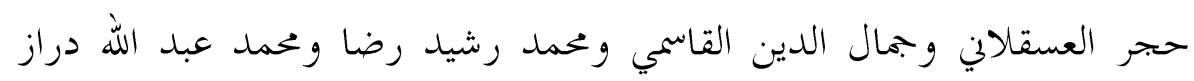
ومحمد أمين الشنقيطي والشيخ محمد متولي الشعراوي . وفريق آخر من العلماء يمنع هذا اللون من التفسير ، بل وينكره ويعارضه ،

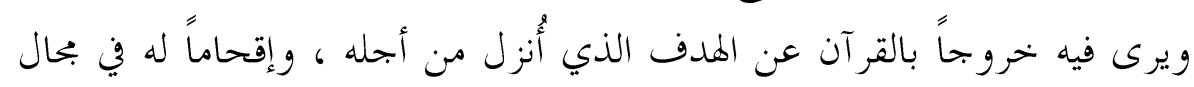


التجريب العقلي الذي يخطئ ويصيب ، لأن التفسير العلمي يُعِرِض القرآن

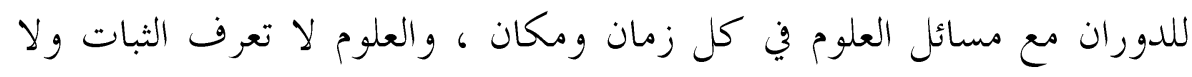

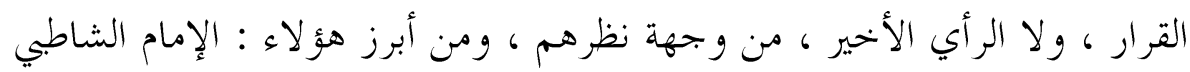

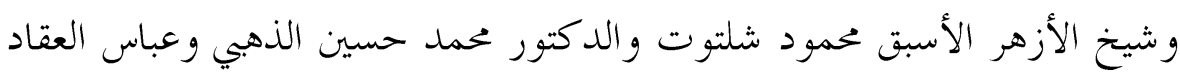

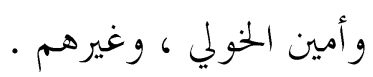

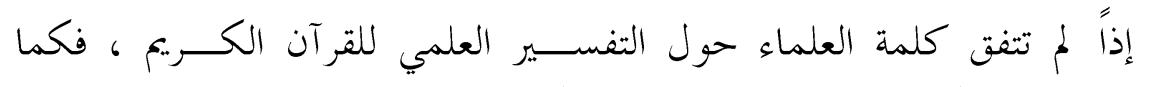

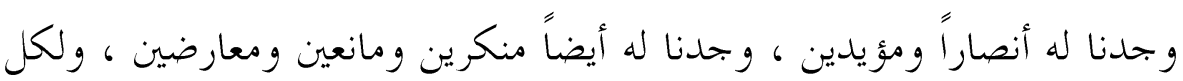

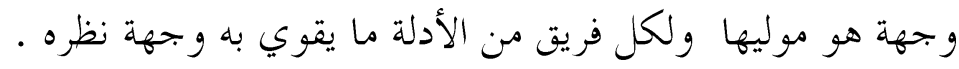

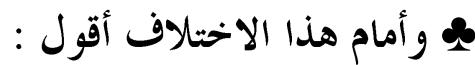

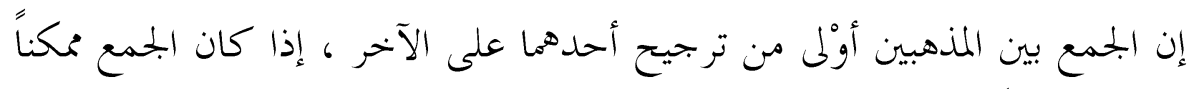

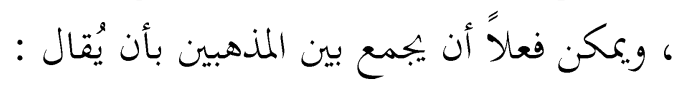

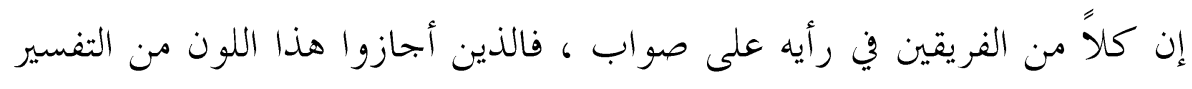

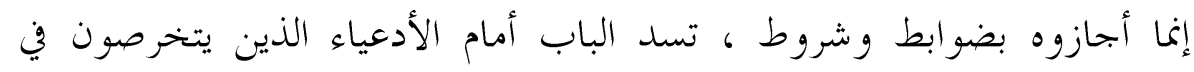

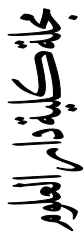

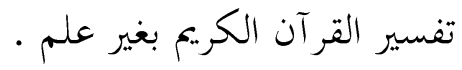

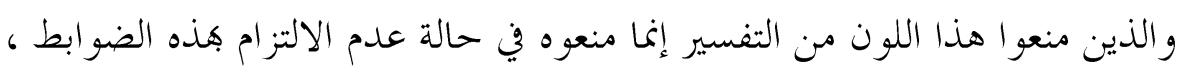

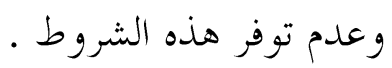

هـ فإذا توفرت الضوابط والشروط لهذا اللون من التفسير قبلناه ، وإلا منعناه

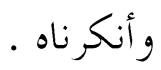

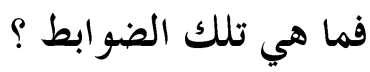

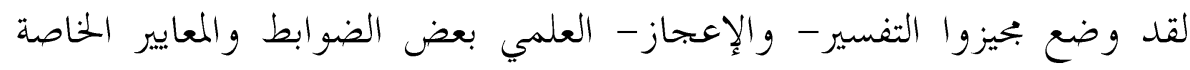

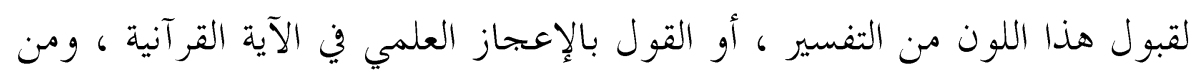

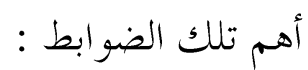

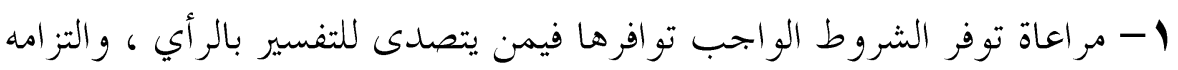

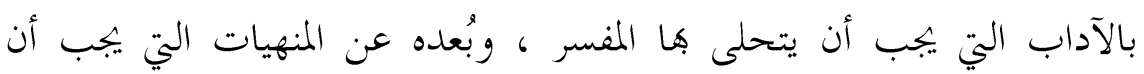

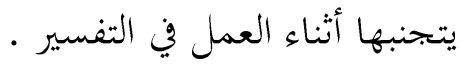


Y-ثبوت الحقيقة العلمية من قِبَل العلماء المتخصصين ، و بشكل مستقر .

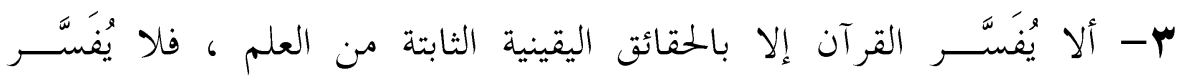

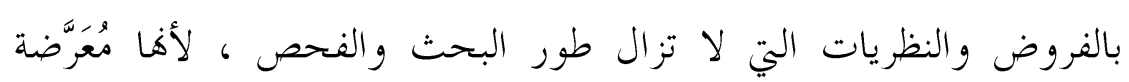

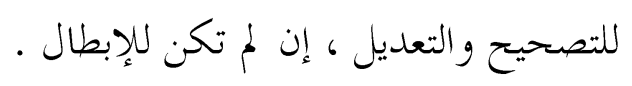

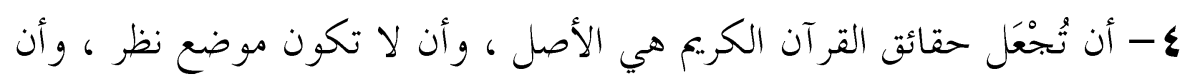

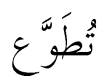

لها الحقائق الكونية، فما وافقها من حقائق الكون قُبلَ، وما خالفها أو عارضها

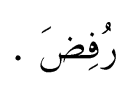

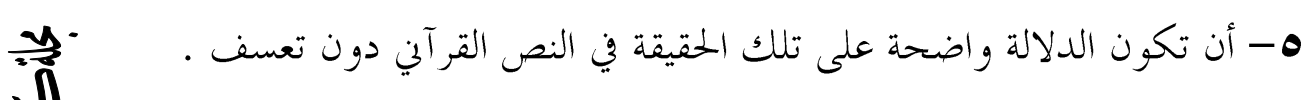

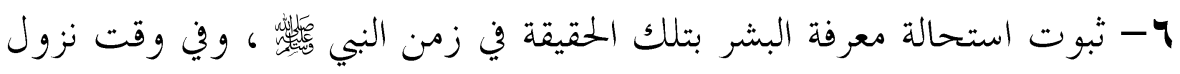
القر آن الكريم

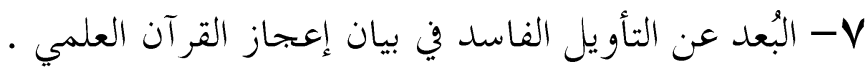

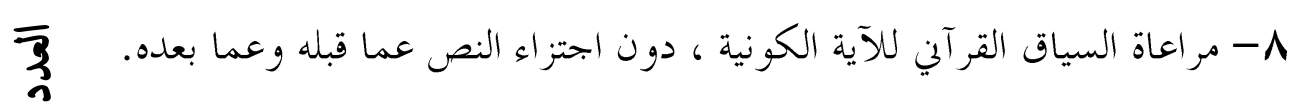

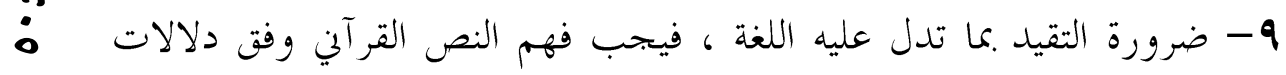
الألفاظ في اللغة العربية ، وووفق قوروند اعد النحو و البلاغة. .........

\section{臮}

يجلدر بنا قبل البدء مع آيات الإعجاز العلمي في سورة الفرقان ، أن نتعرف على

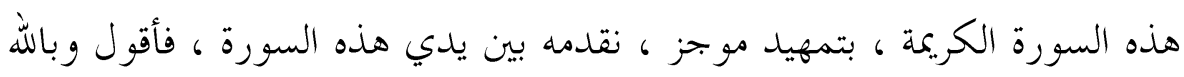

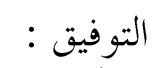
أولاً : ترتيب السورة : سورة الفرقان هي الخامسة والعشرون في ترتيب

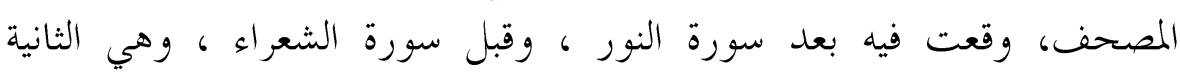

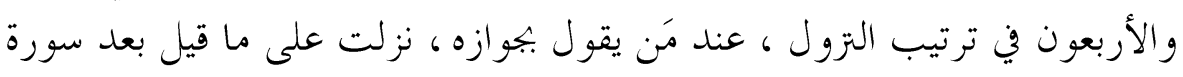

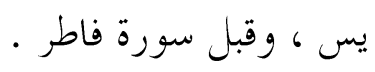


ثانياً : زمان نزول السورة : سورة الفرقان سورة مكية بتمامها في قول جمهور

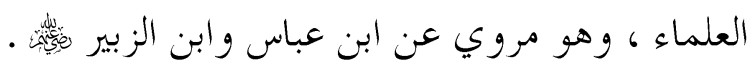

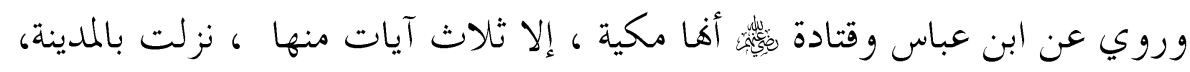

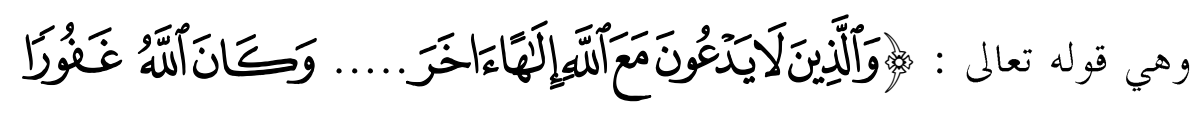

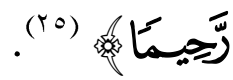

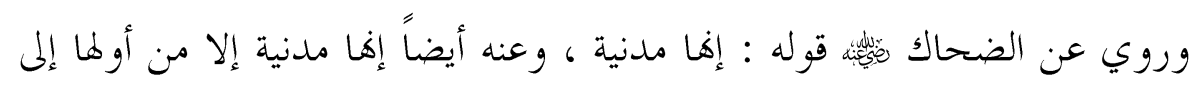

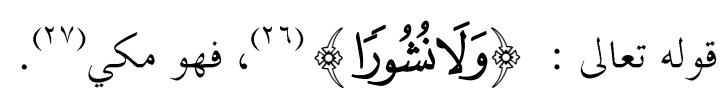

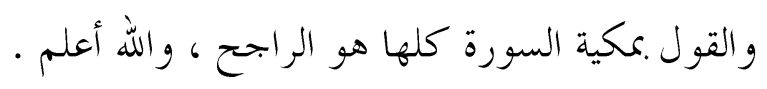

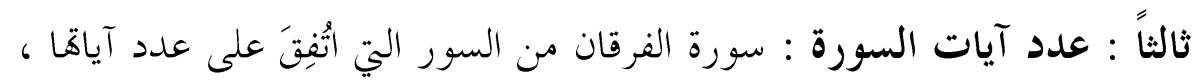

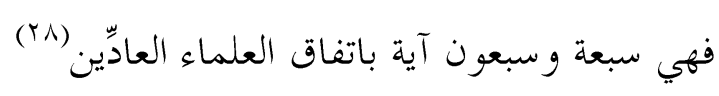

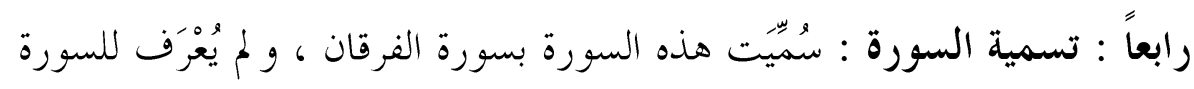

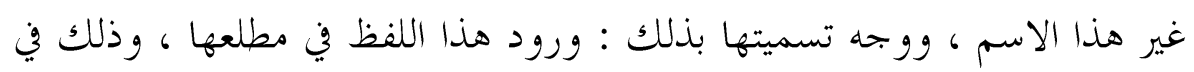

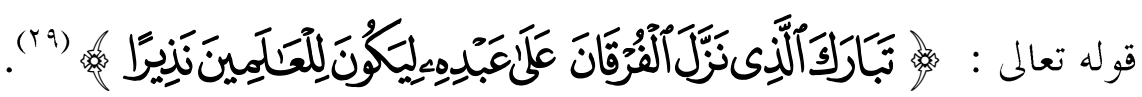
خامساً : مناسبة السورة لما قبلها :

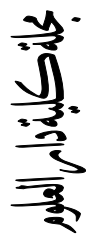
119

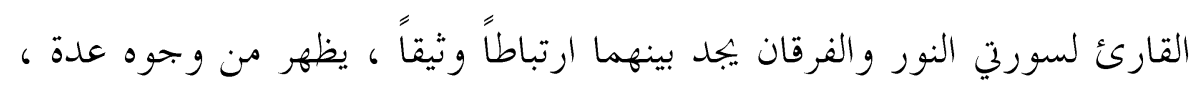
: منها

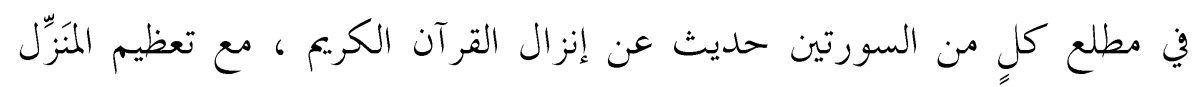

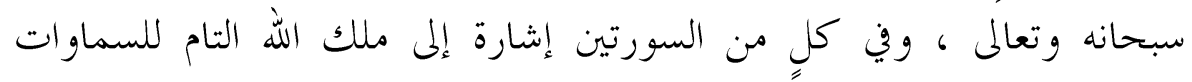

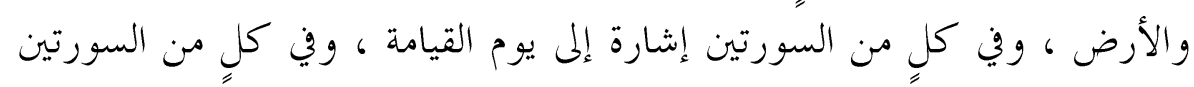

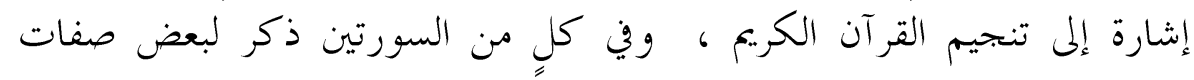

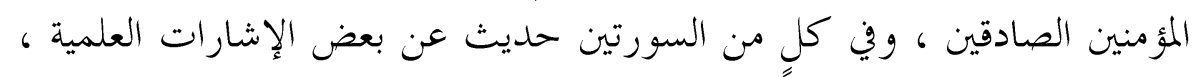

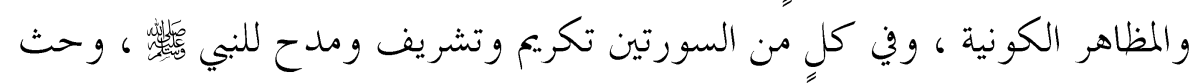

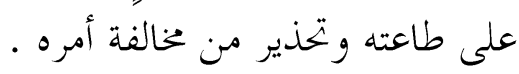


وقال أبو حيان والألوسي : ومناسبة أول هذه السورة لآخر ما قبلها :

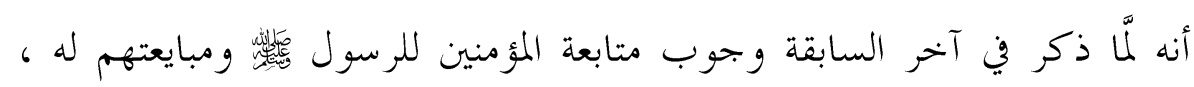

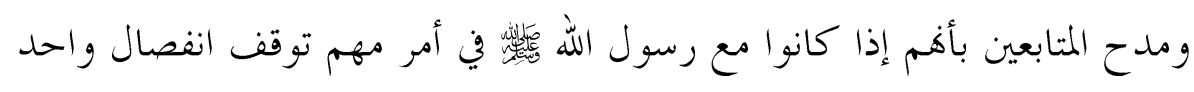

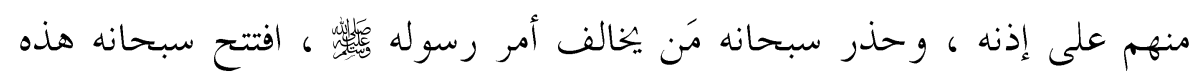

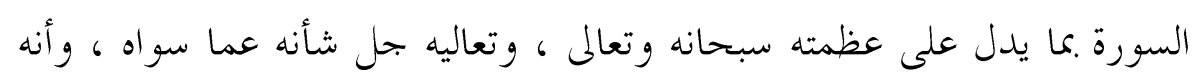

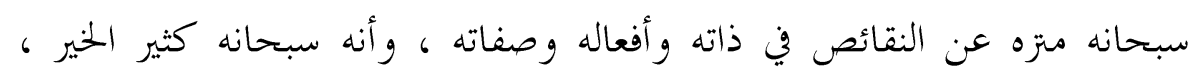

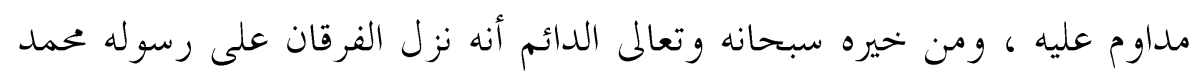

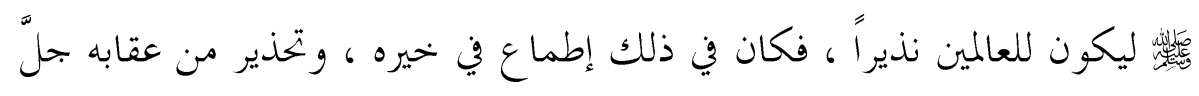

سادساً : أهم الموضوعات التي اشتملت عليها السورة :

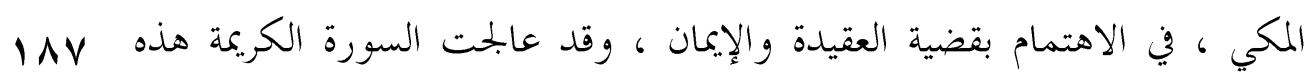
$\overline{\overline{3}}$ القضية من خلال تعرضها للموضوعات الآتية :

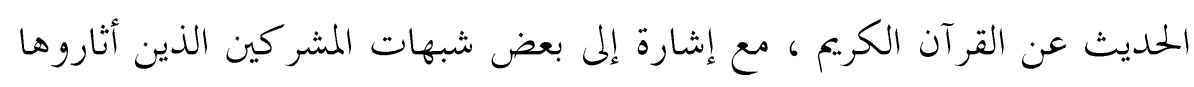

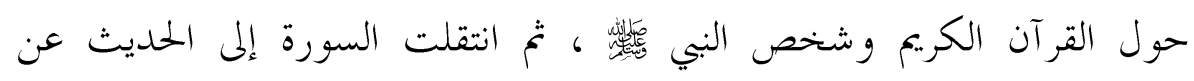

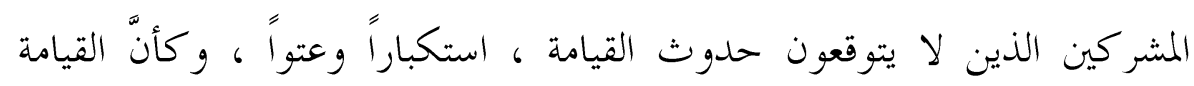

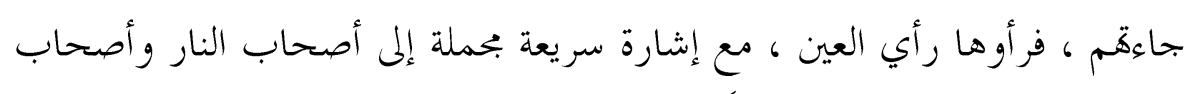

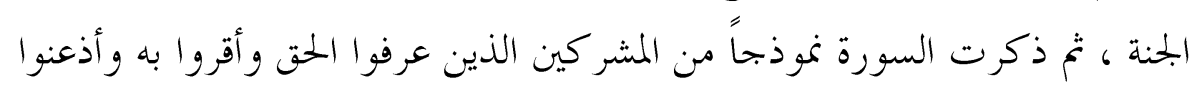

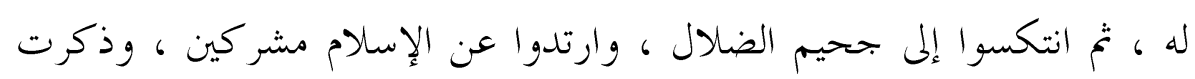

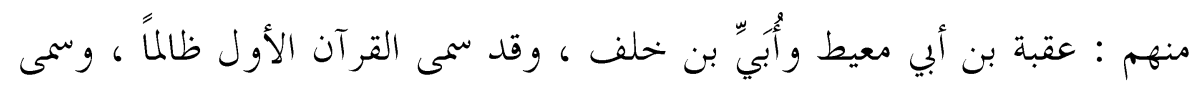

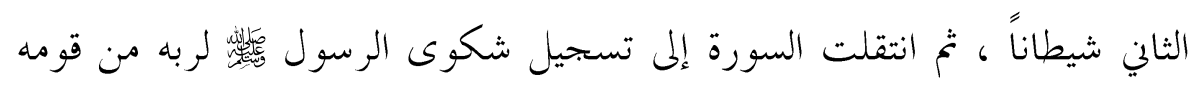

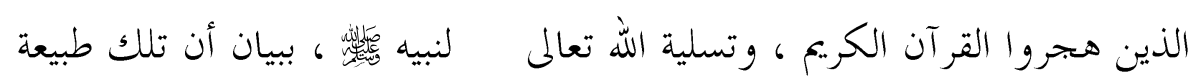

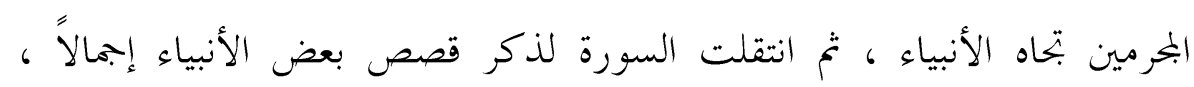


موضحة ما حل بأقوامهم المكذبين ، ثم انتقلت السورة للحديث عن دلائل قدرة

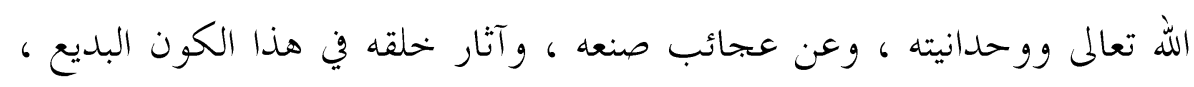

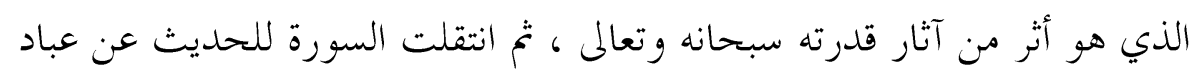

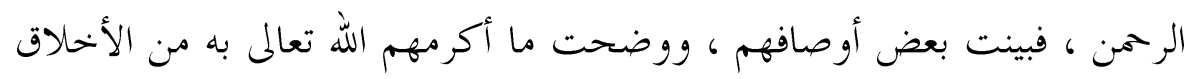

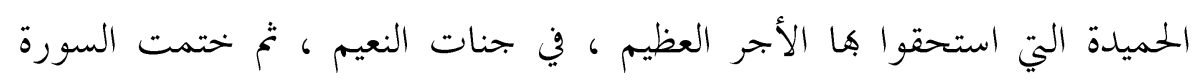
الكريمة بتصوير هوان البشرية على الله سبحانه . .... ....

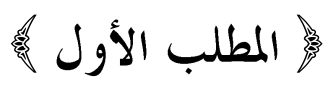

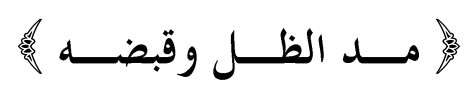

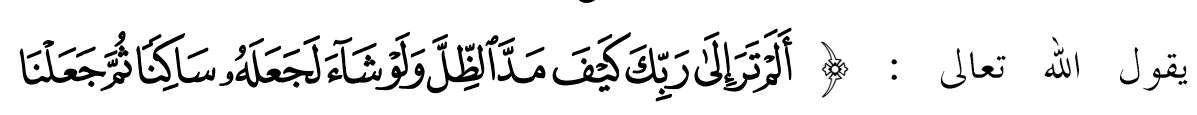

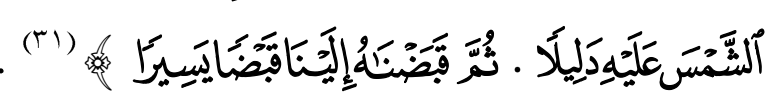

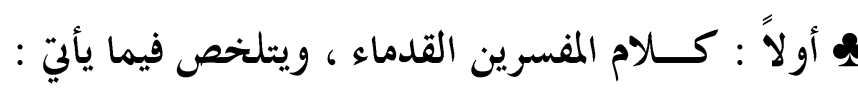

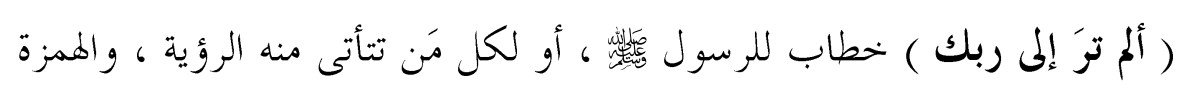

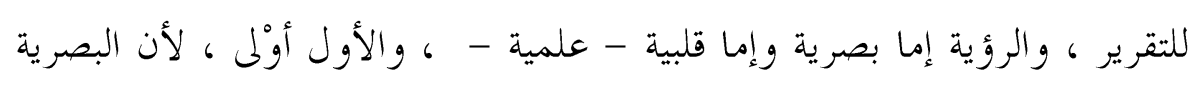

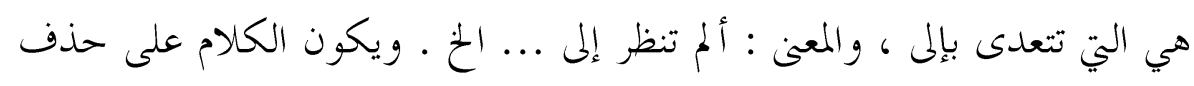

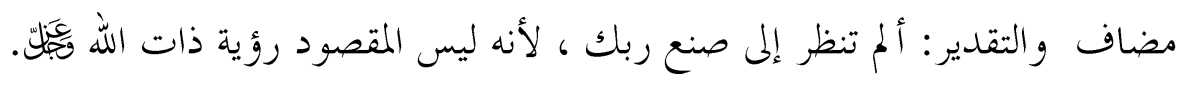

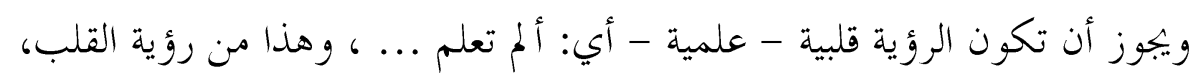

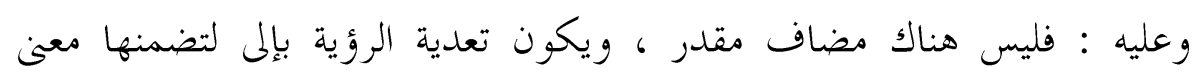

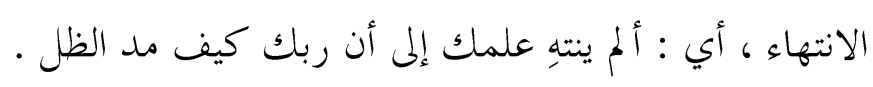

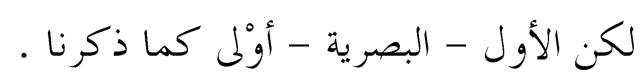

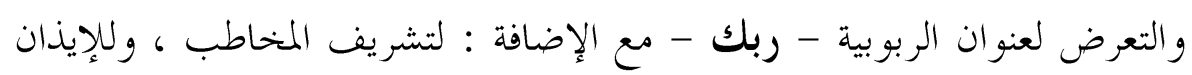

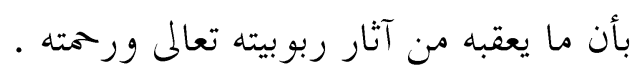




\section{الإعجاز العلمي في سورة الفرقان}

( كيف مد الظل ) كيف : سؤال عن الحال ، و الكلام على القلب ، و التقدير : ألم تر إلى الظل كيف مده ربك ، والمد : البســـ ، فمَدَ الظل أي جعله بمتد و وينبسط فينتفع به الناس . وحقيقة الظل - كما قال المفسرون - هو الأمر المتوسط بين الضوء الخالص

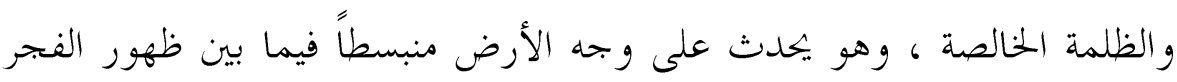

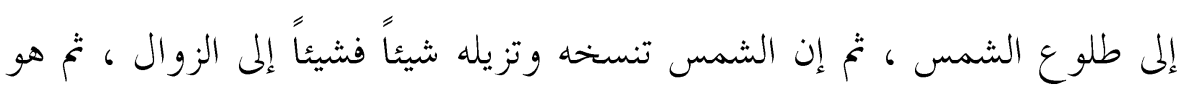
ينسخ ضوء الشمس من وقت الزوال إلى الغروب ، و ويسمى فيئًا (rr) . والظل هنا - في قول الجمهور - من طلوع الفجر إلى طلوع الشمس ، وقيل هو

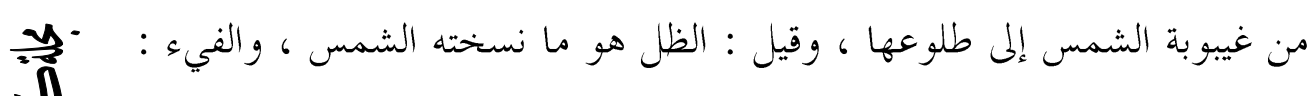

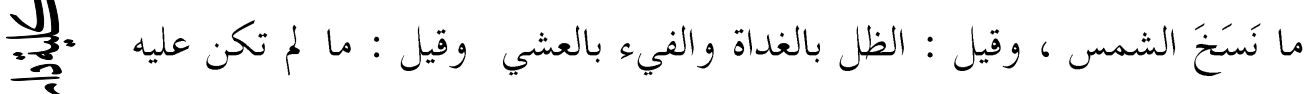

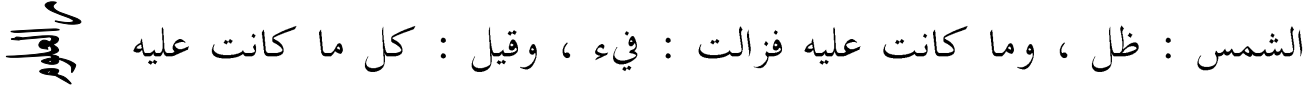

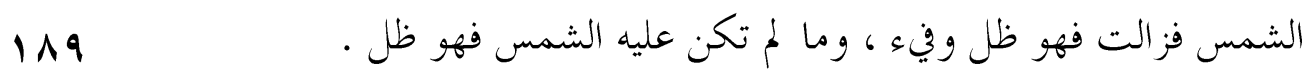

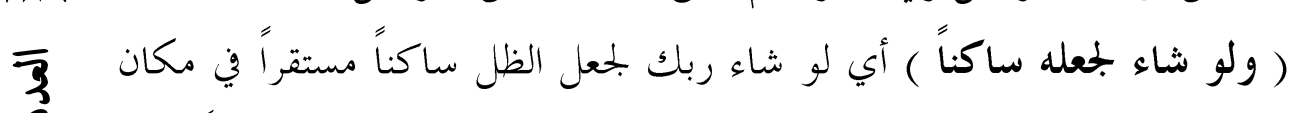

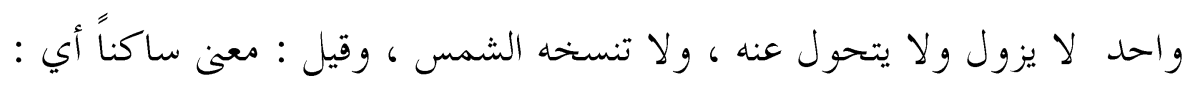

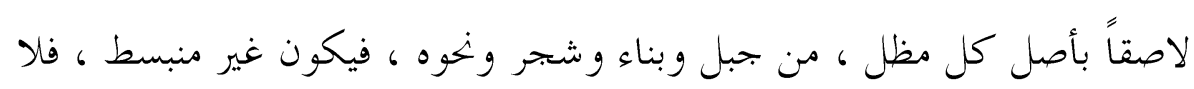

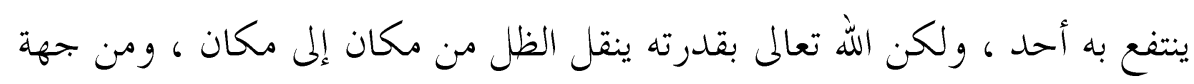

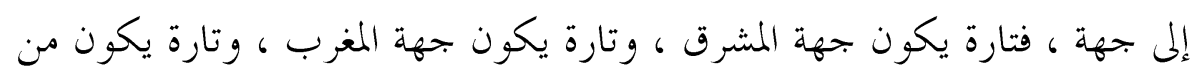

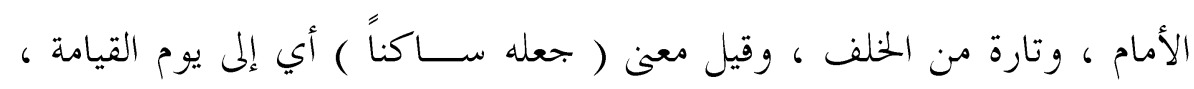
وقيل المعنى : لو شاء لمنع الشمس الطلوع .

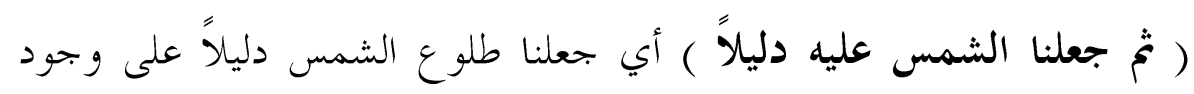

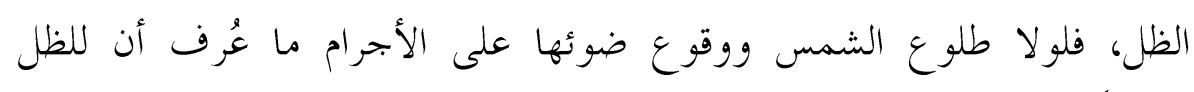

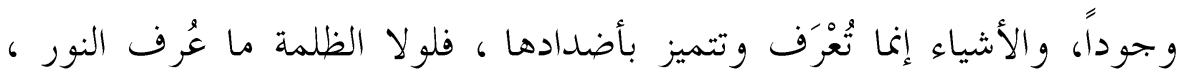

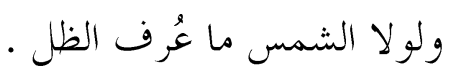


فالدليل : فعيل بمعنى الفاعل ، وقيل هو فعيل بمعنى المفعول ، كالقتيل ، والمعنى :

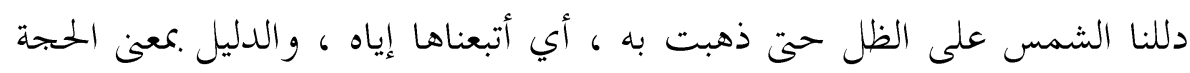
والبرهان ، وهو الذي يكشف المشكل ويوضحه ، و لم يؤنث الدليل - مع أنه صفة للشمس - لأنه في معنى الاسم، كما يقال : الشمس برهان ، و والشمس حقد وهن.

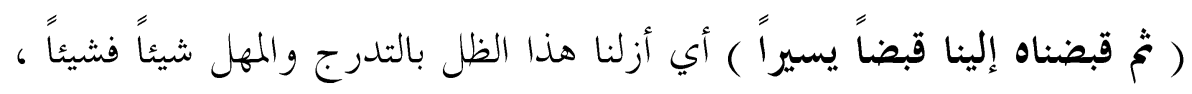

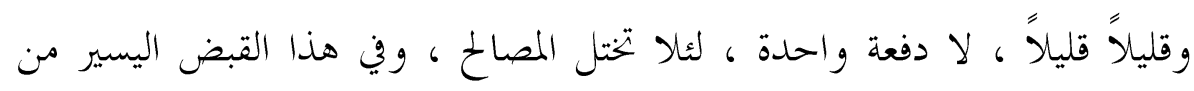

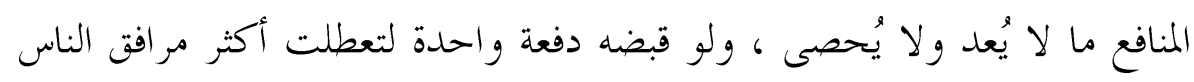

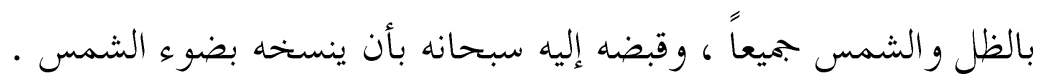

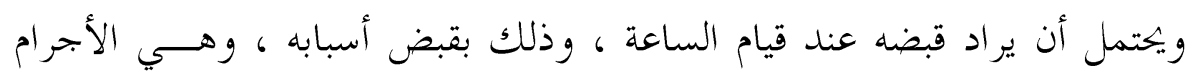
التي تبقي الظل ، فيكون قد ذكر إعدامه بإعدام أسبابه ، كما ذكر إنشاءه

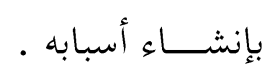

وقوله تعالى ( إلينا ) يدل على ذلك ، و التعبير بالماضي - قبضناه - لتحقق وقوعه. 势 وقوله تعالى ( إلينا ) للتنصيص على كون مرجع الظل إليه هَيَّلَّ ، لا يشار كه

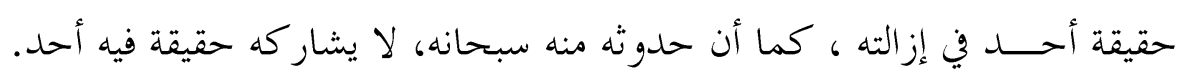

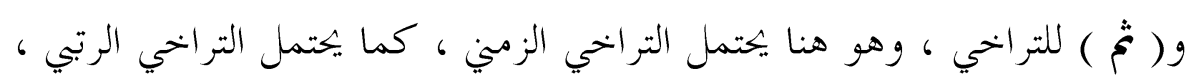
19.

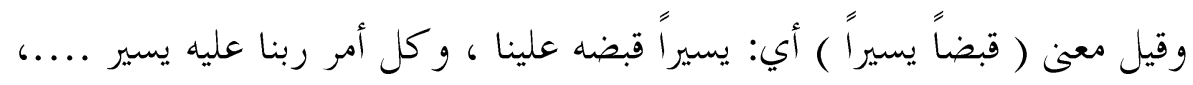

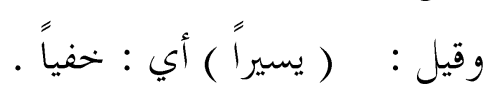

وهكذا بند القول الكريم في تعبير رائع يرسم لنا هذا المشهد العظيم ، مشهد

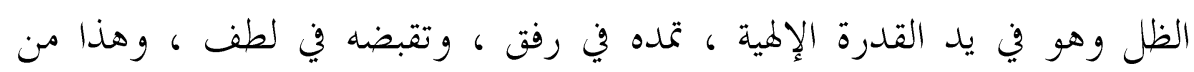

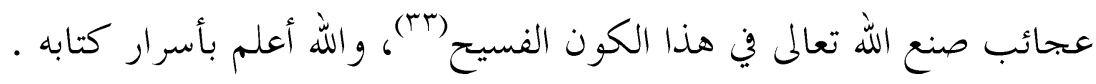
مو ثانياً : حقائق العلم الحمديث ، ووجه الإعجاز في الآية : يُعد الحديث عن مد الظل وقبضه من الإشارات العلمية الواردة في القرآن الكريم ، ووجودها يدل على وجود الإعجاز العلمي في القرآن ، وقد كان المفسرون 


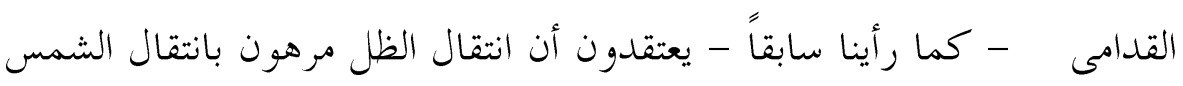

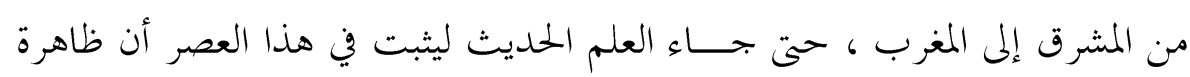

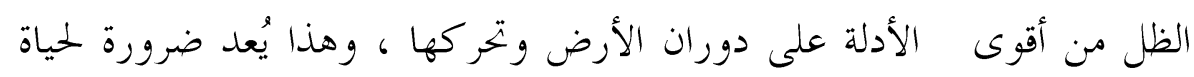

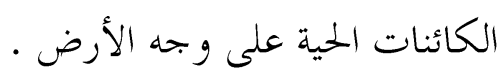

يقول الدكتور موريس بو كاي : أما ظاهرة الظل وانتقاله ، تلك التي بند تعليلها

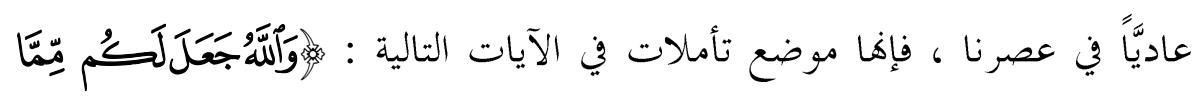

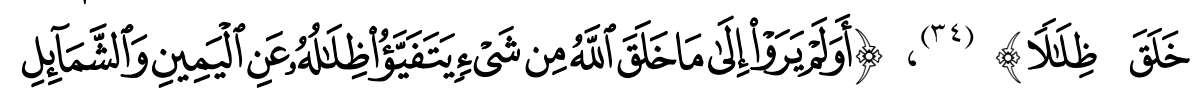

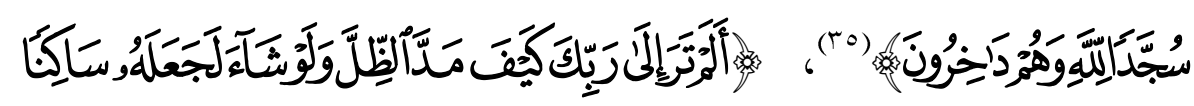

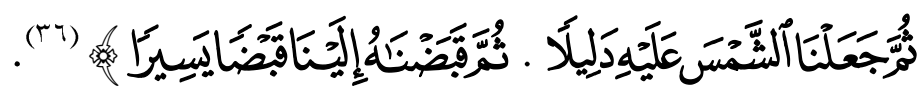

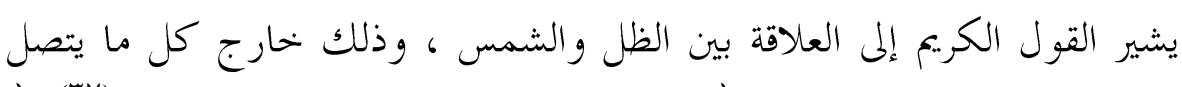

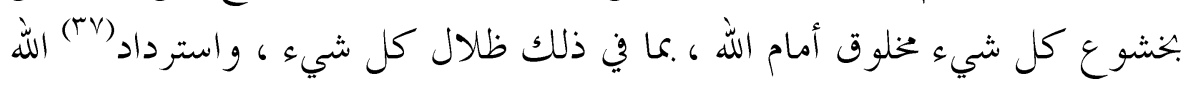
191

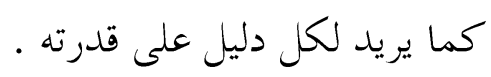

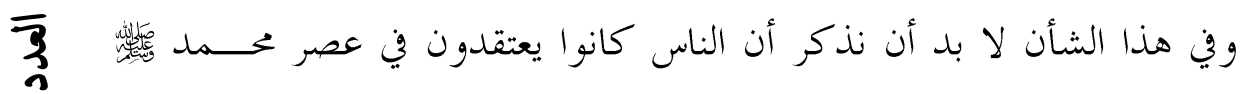

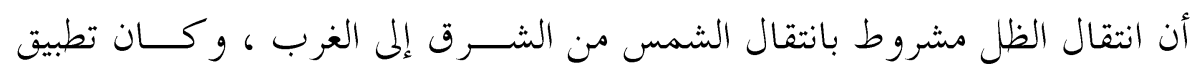

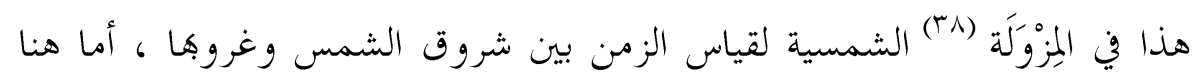

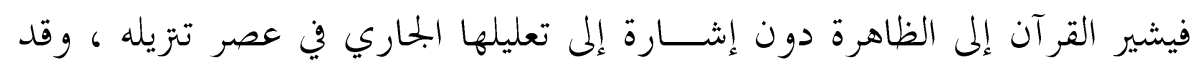

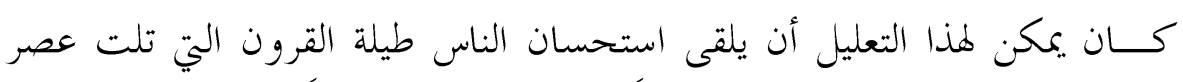

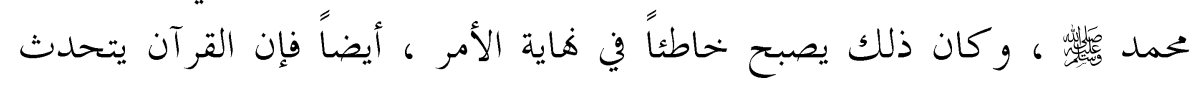

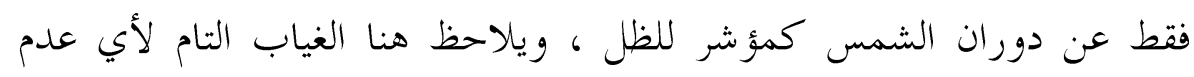

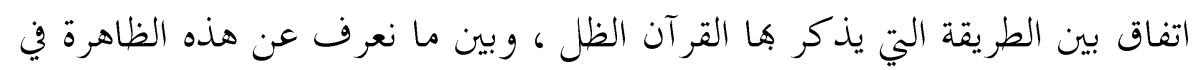

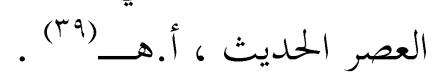

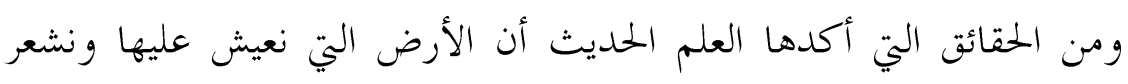

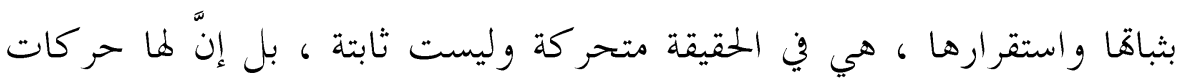


فمما أثبته العلم الحديث أن للأرض حركات ثلاث : الأولى : حول نفسها ،

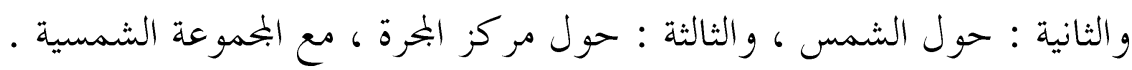

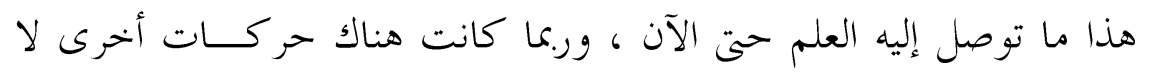

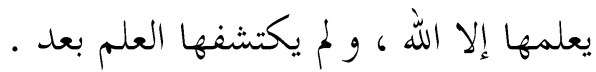
أما دوران الأرض حول نفسها - على ما أكده العلم الحديث - فخلاصته على ما جاء في الموسوعة الأكاديمية الأمريكية : إن الأرض- من الناحية الفلكية - تدور حول نفسها وتتحرك في محورها الوهمي في مدة يوم واحد ، و وينتج عن هذا الدوران حدوث الليل و النهار وتعاقبهما ، كما ينتج عنه اختلاف التوقيت على سطح الأرض ، حسب شروق الشمس وغروبها . يقول علماء الفلك : إن الأرض تحتاج لتدور حول نفسها مدة تبلغ بر ساعة

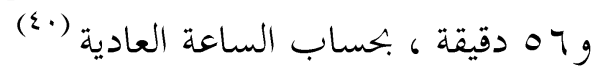
وحسب المعلومات المسجلة والمؤكدة فلكياً فإن سرعة دوران الأرض حولة المول

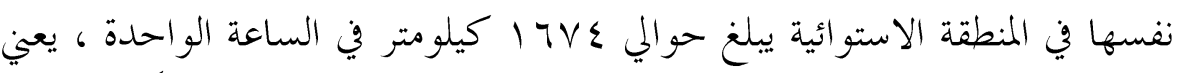

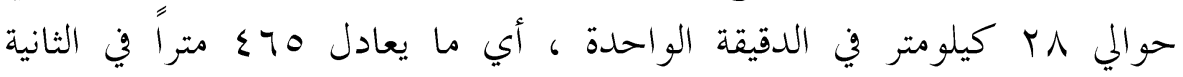

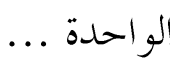
وأما دوران الأرض حول الشمس فخلاصته - على ما أكده العلم الحديث

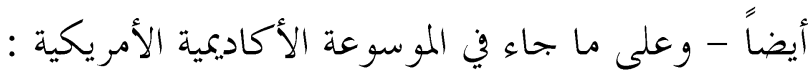

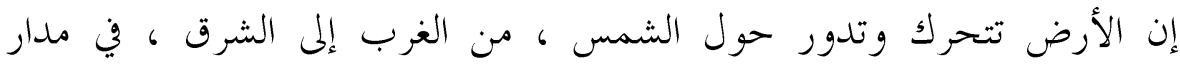

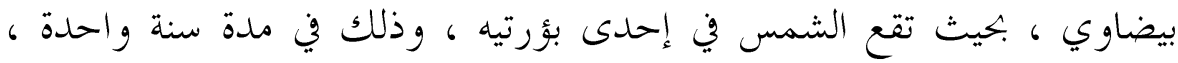

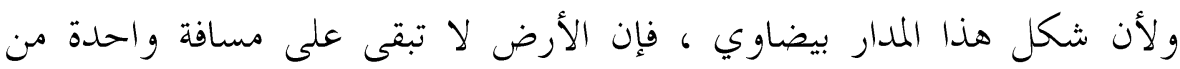

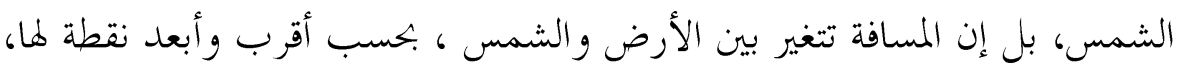

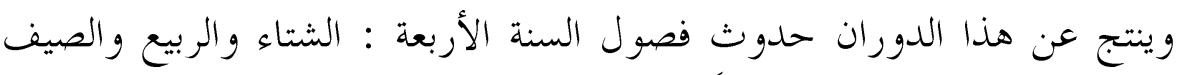

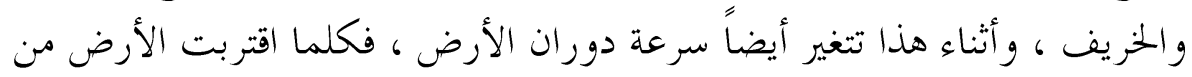

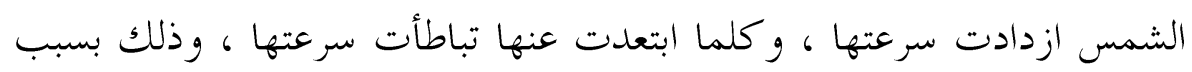
ازدياد أو انخفاض قوة الجحاذبية المؤثرة هـا وليا 


\section{الإعجاز العلمي في سورة الفرقان}

و وحسب المعلومات المسجلة والمؤكدة فلكياً في هذا المحال أيضاً ، فإن متوسط

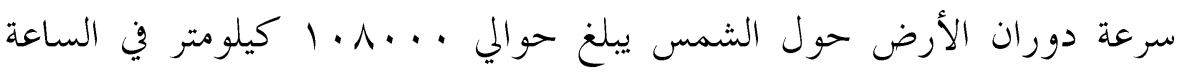

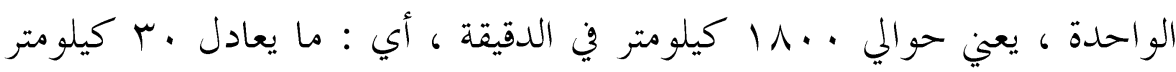

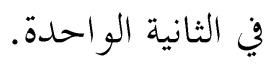
مما سبق يتضح لنا أن الأرض تدور دورتين أساسيتين ، الأولى منها دورة يومية حول نفسها ، من أجل حدوث ظاهرة تعاقب الليل والنهار، و الثانية دورة سنوية حول الشمس ، من أجل حدوث ظاهرة الفصول الأربعة .

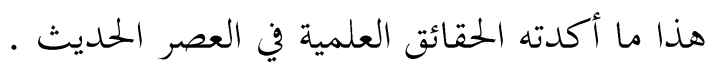

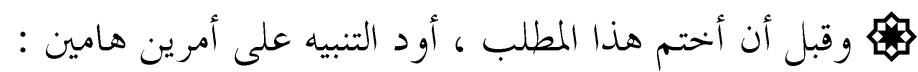

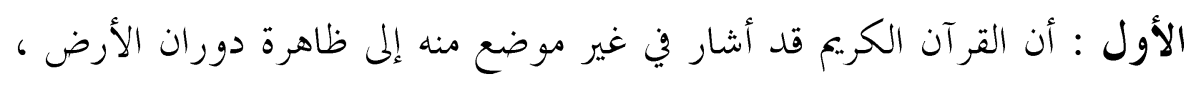

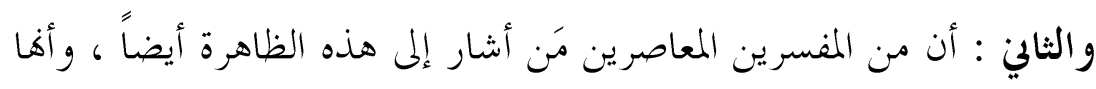

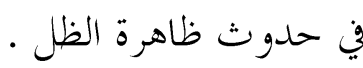

أما الأمر الأول : فإن المتدبر لآيات القرآن الكريم يجده قد تحدث في آيات كثيرة عن دوران الأرض ، وإن كان ذلك بطريق غير مباشر ، ومن هذه الآيات

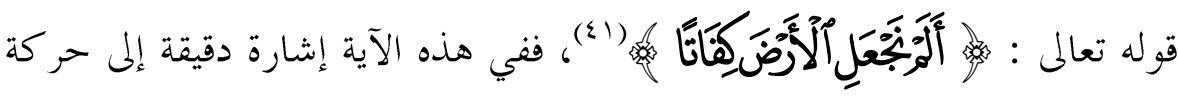

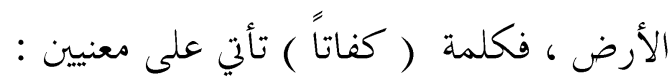

ا- الضم والجمع ، وهذا ما ذكره قدامى المفسرين في معنى الآية ، قالوا معناها : ألم بجعل الأرض ضامة للأحياء على ظهرها ، و الأموات في باطنها ، تضمهم تهم

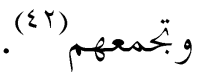

r- السرعة ، قال في الصحاح : وركَفتَ أي : أسرع ، والكَفْتُ : السَّوْق

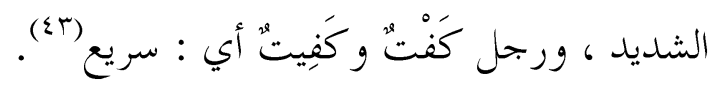

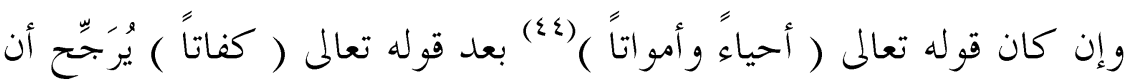

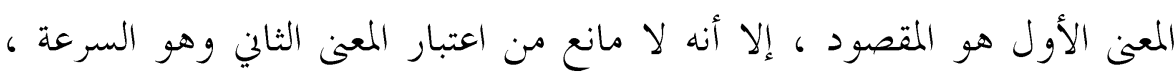
و القر آن حمَّال أوجه كمَ كما نعلم . 


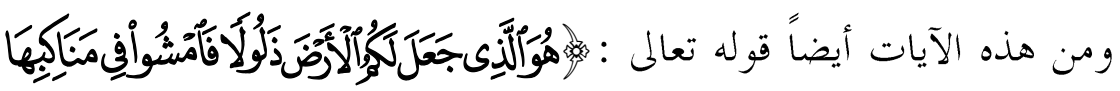

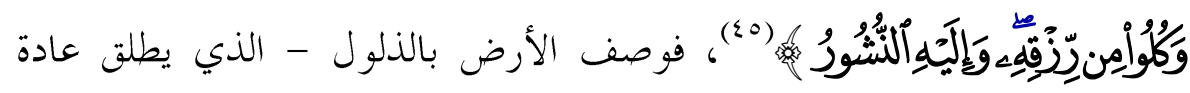

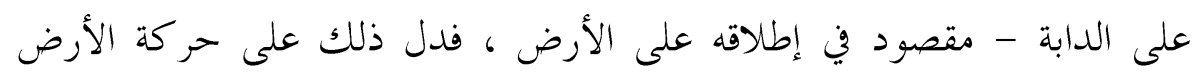
وعدم ثباها .

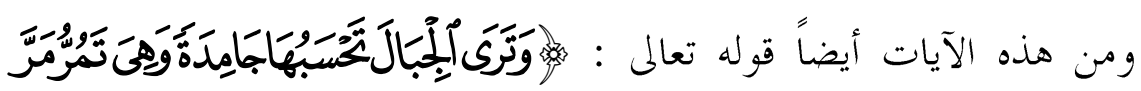

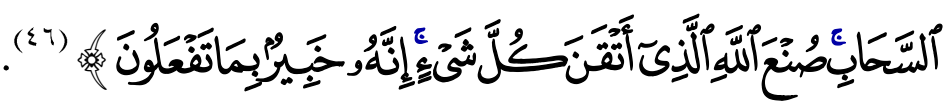

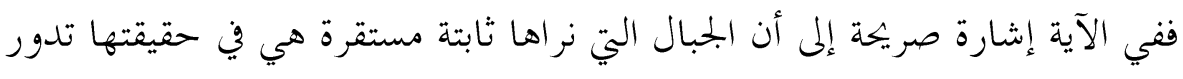

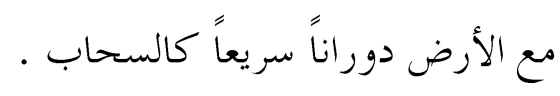

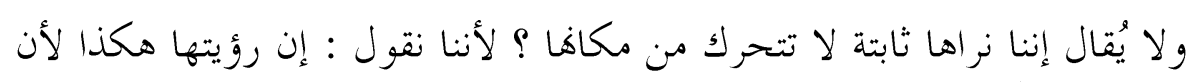

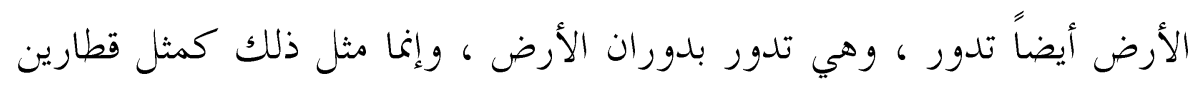

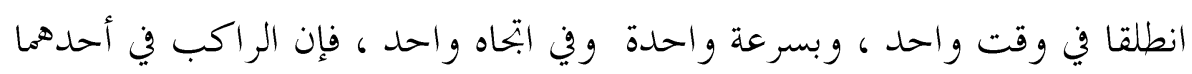

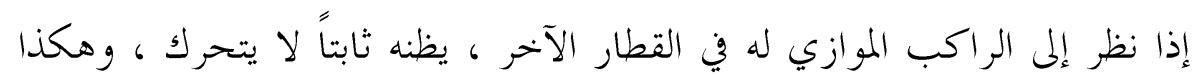

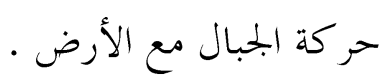
و وأما الأمر الثنالي : فإن من المارض المفرين المعاصرين مَن أشار إلى ظاهرة دوران

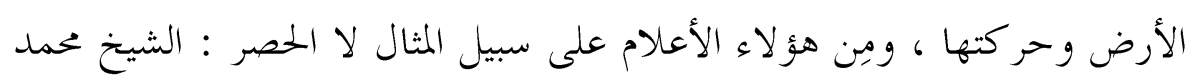

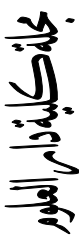

195

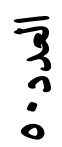

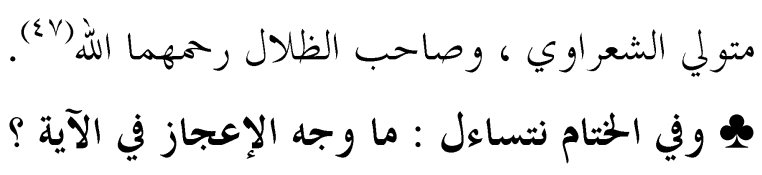

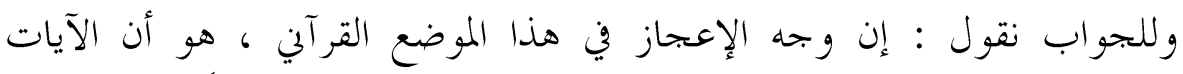

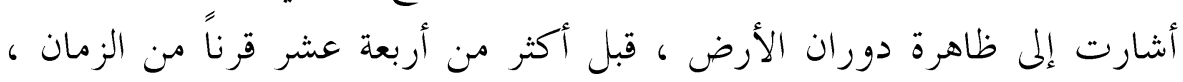

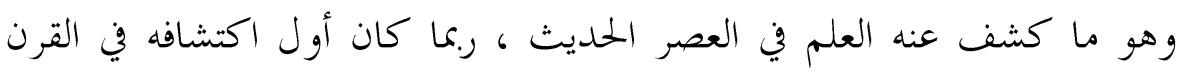

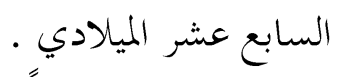
فلم يعرف الناس شيئًا عن دوران الأرض قبل هذا القرن .

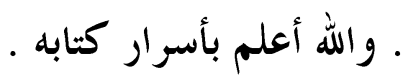




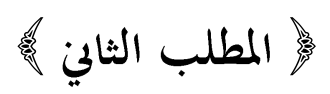

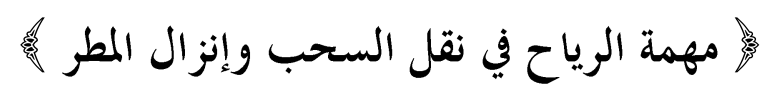

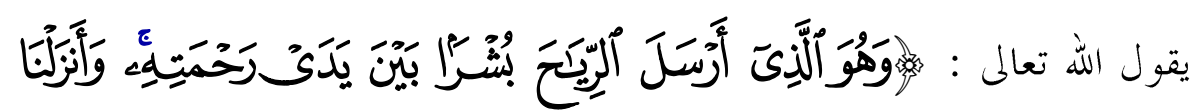

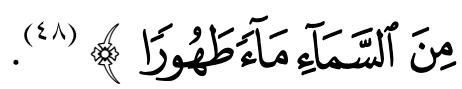

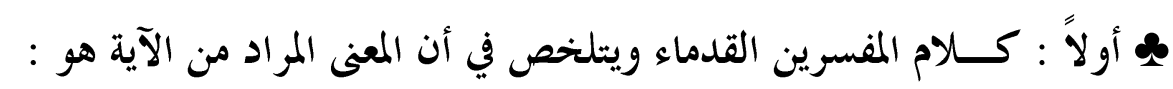

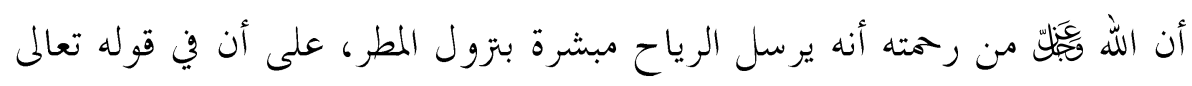

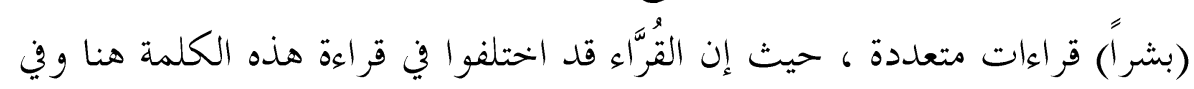

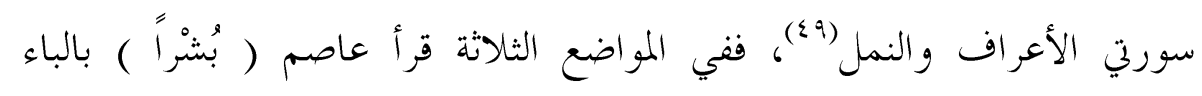

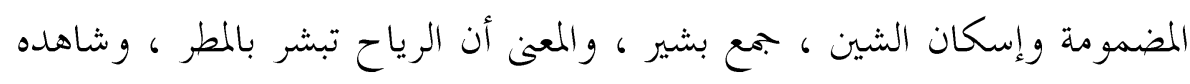

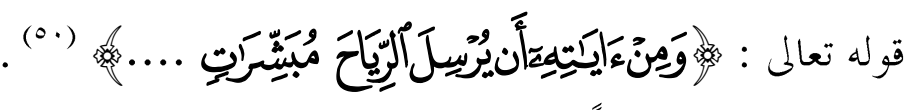

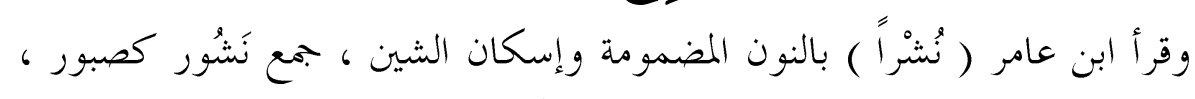

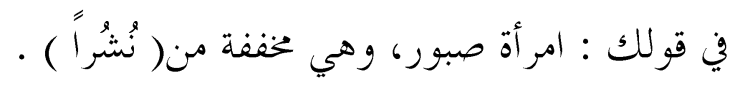
$\bar{\vdots}$

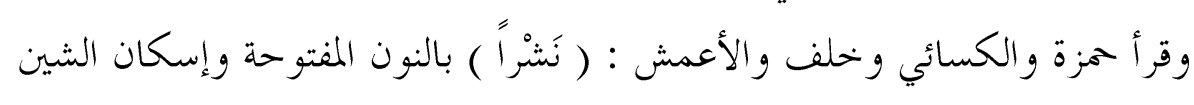

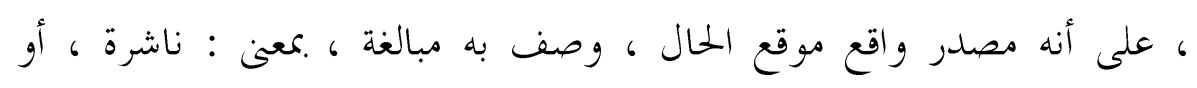

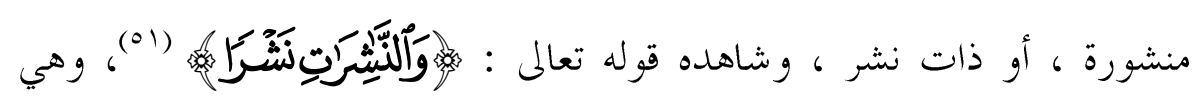

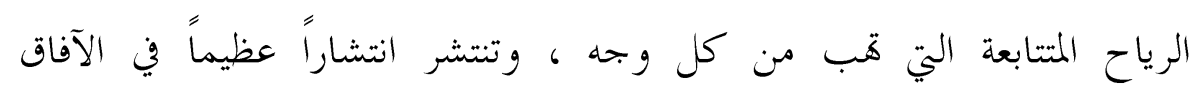
والمهات.

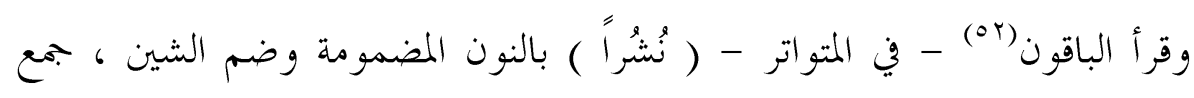

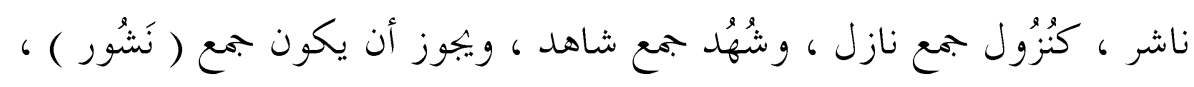

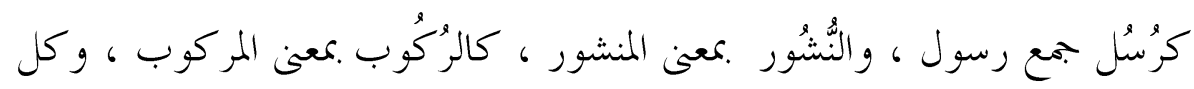

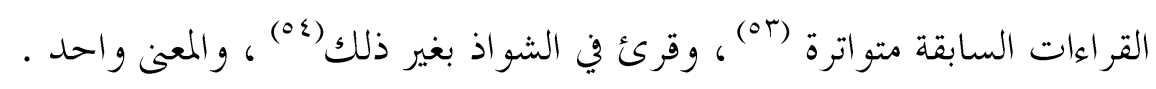

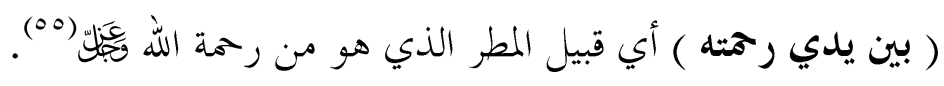


وأصل عبارة ( بين يدي ) لبيان المكان الذي يكون أمام الشـــصص ، محصوراً بين جهيت بمينه وشثماله ، فحقيقة قولهم ( جلست بين يدي فلان ) أن بتحلس بين العضوين ، فتجوّز بذلك عن الجهتين المقابلتين ليمينه وشثماله قريباً منه ، بإطلاق

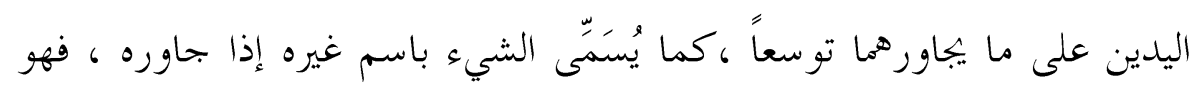

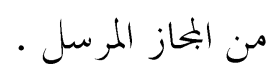

وقد يتوسع في هذه العبارة ( بين يدي ) لتشمل الأمور المعنوية أو الزمانية ، ومنه

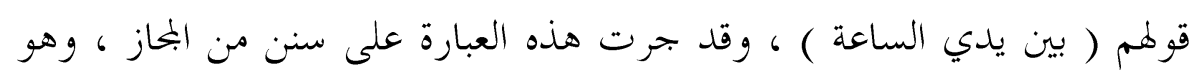

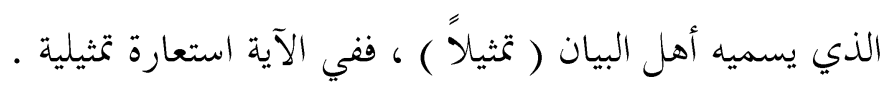

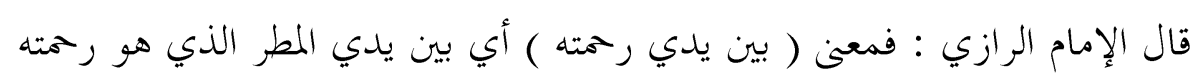

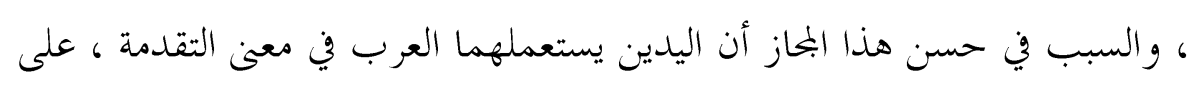

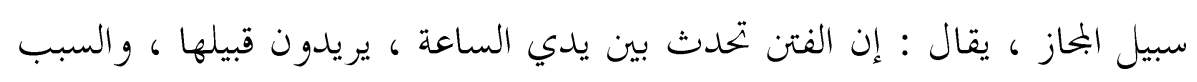

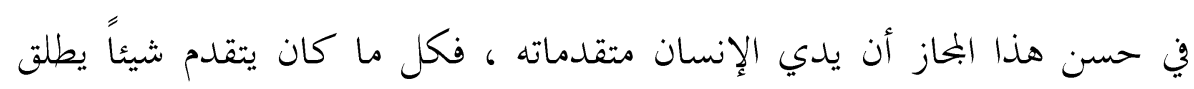

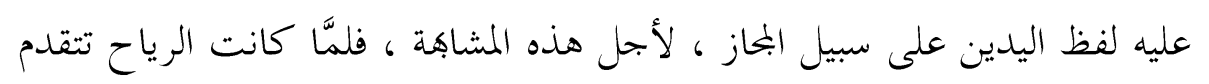

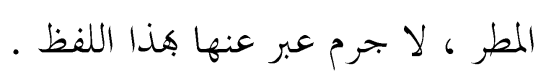

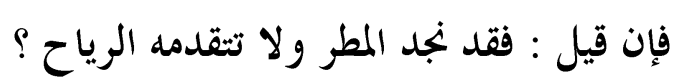
势 197

فنقول : ليس في الآية أن هذا التقدم حاصل في كل الأحوال ، فلم يتوجه السؤال.

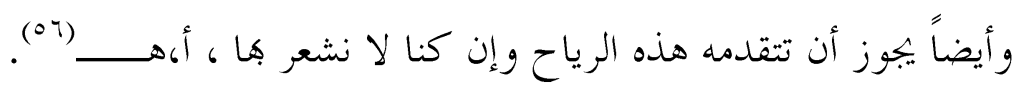

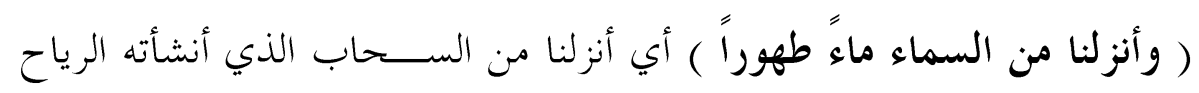

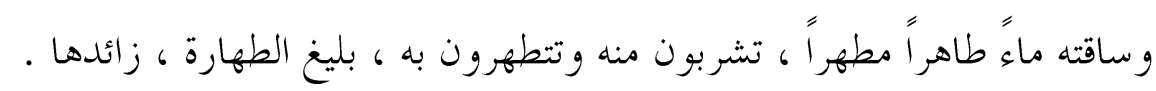
والالتفات إلى نون العظمة في قوله ( وأنزلنا ) لإبراز كمال العناية بالإنزال ، لأنه نتيجة ما ذكر من إرسال الرياح ، أي أنزلناه بعظمتنا ، بما رتبنا من إرسال الرياح

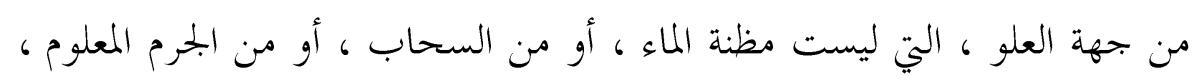

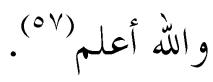


مِ ثانياً : حقائق العلم الحديث ، ووجه الإعجاز في الآية :

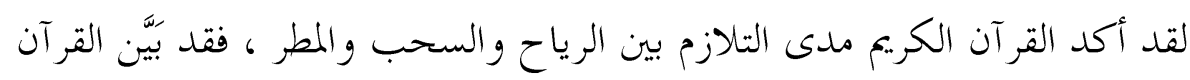
أن الرياح هي التي تدفع السحاب وتحمله ، وهي كذلك التي تنشأه ، وهذا ما لها قرره العلم الحمديث في حقائقه الثابتة ، والتي تتلخص في أن الرياح هي السبب في

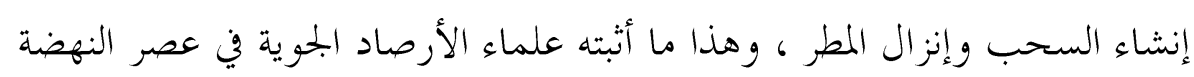
العلمية الم

فالرياح إذاً كما أها من أهم العوامل الأساسية في تلقيح كثير من النباتات ، هي كذلك تقوم بعملية تلقيح السحاب ليجود بالمطر .

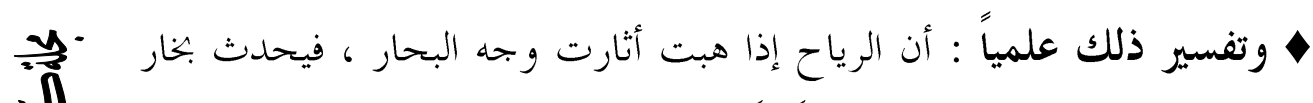

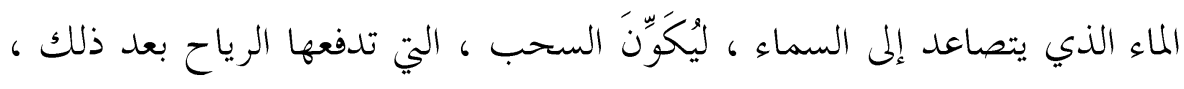
إلى حيث يشاء الله تعالى .

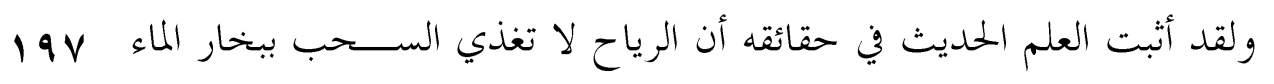

$\overline{3}$ وحده بل إذا تقوم بعملية تلقيح السحاب .

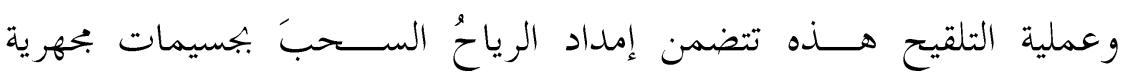

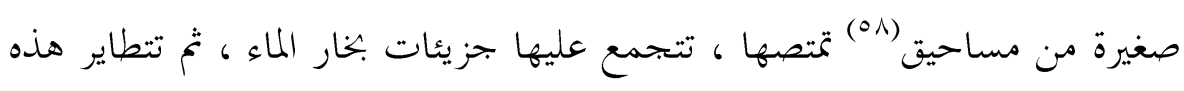

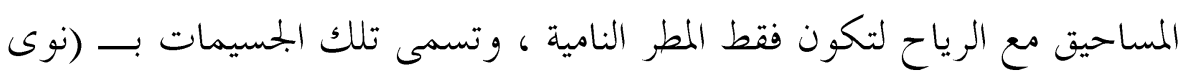
التكاثف ) ، وهي المرادة من كلمة ( لواقح ) ، التي جاءت في القرآن الكريم ، في

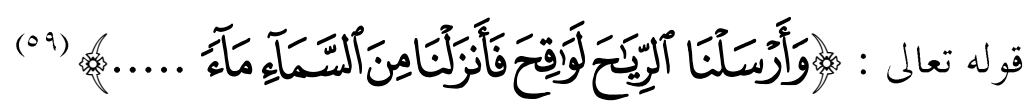
يقول الدكتور موريس بو كاي تعليقاً على الآية السابقة :

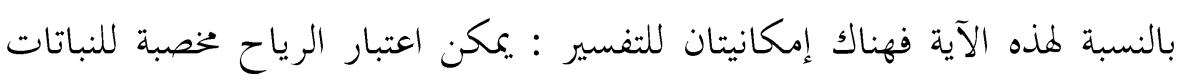
بواســطة نقل اللقاح ، ولكن قد يكون المقصود هو صورة تعبيرية تذكر قياساً

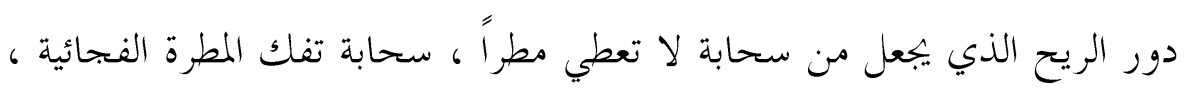

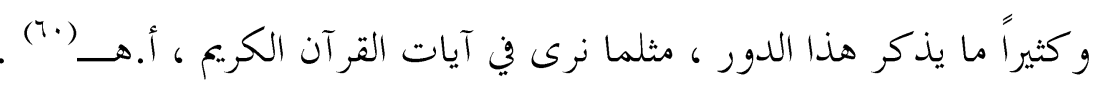




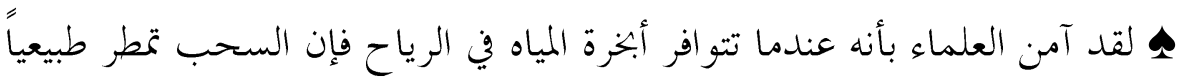

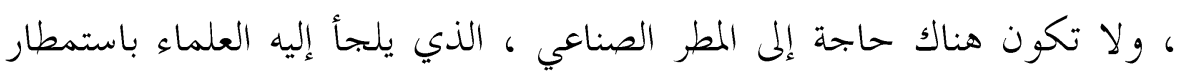

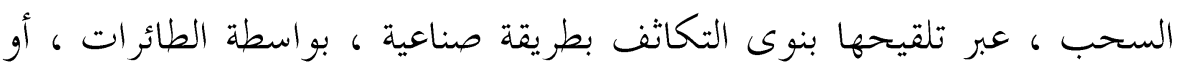

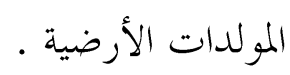
أما إذا كانت الرياح عقيماً فلا سبيل إلى بناح عملية المطر الصناعي ، وسبحان

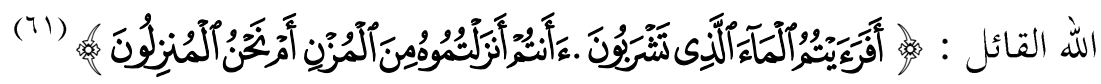

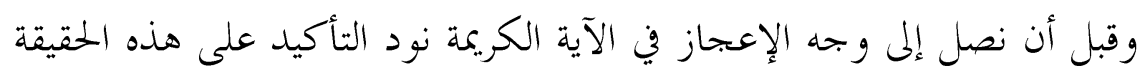

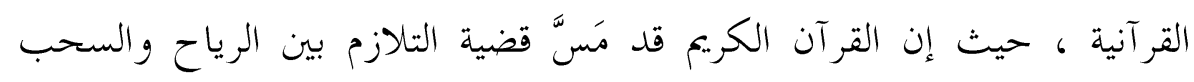

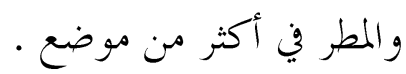
وأشار القر آن الكريم إلى سوق لم الرياح للسحاب وتلقيحها له ، و وكوفا سبباً لإنزال

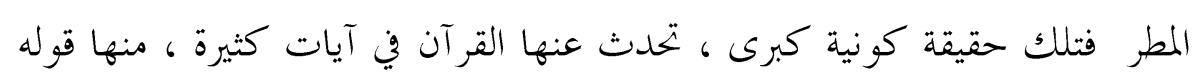

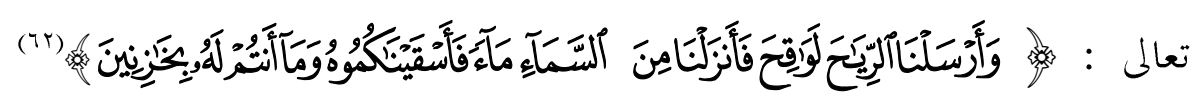

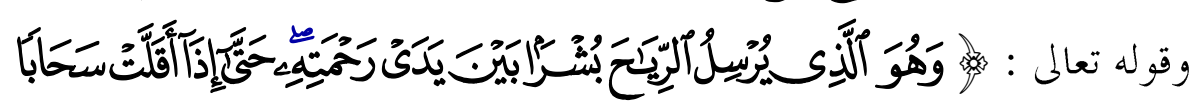

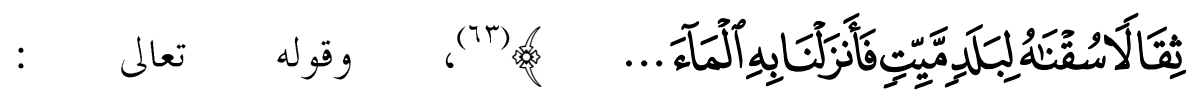

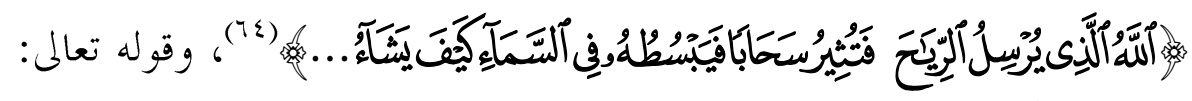

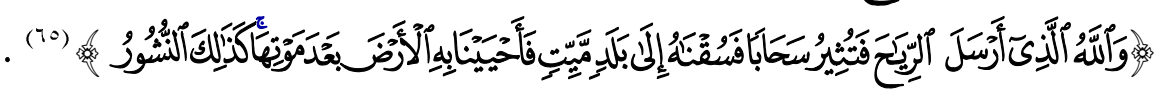
إلى غير ذلك من الآيات التي تمس هذه القضية الكونية الكبرى .

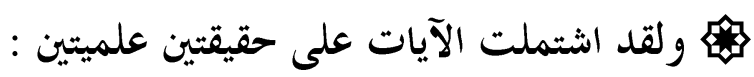

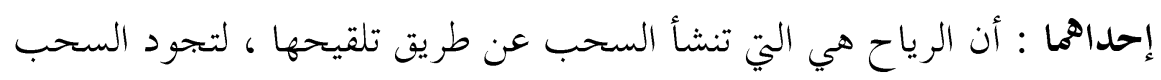
بالمطر . الملان.

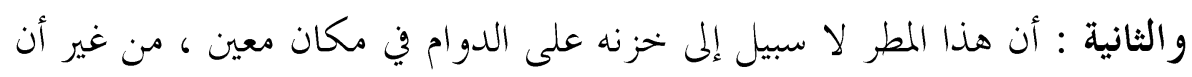

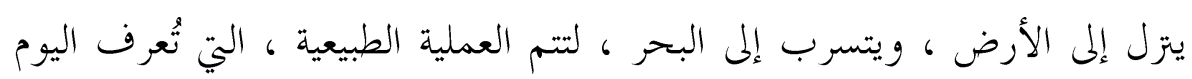

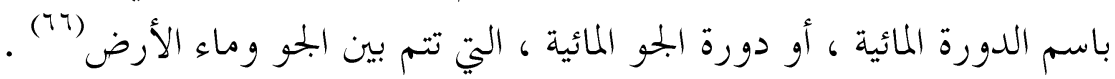

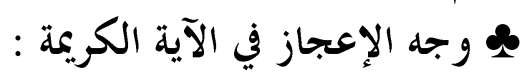


الإعجاز العلمي في سورة الفرقان

إن الإعجاز العلمي في آية الفرقان - الواقعة بين أيدينا - هو أن القر آن الكريم منذ

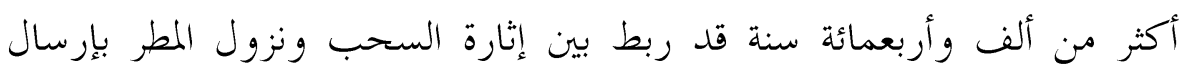

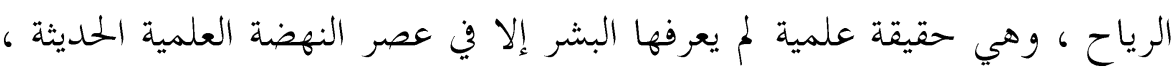
ولم تكن معلومة للناس في عصر نزول القرآن الكريم .

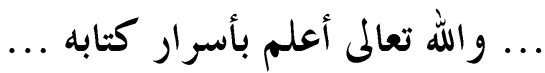

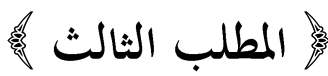

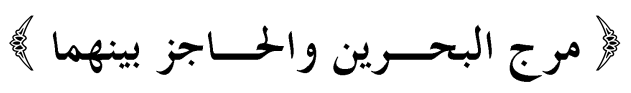

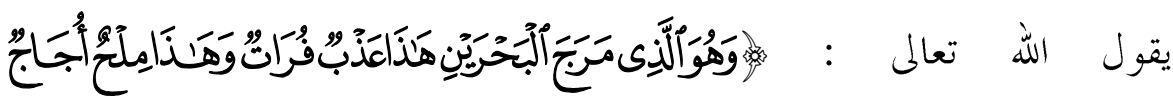

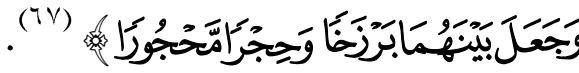

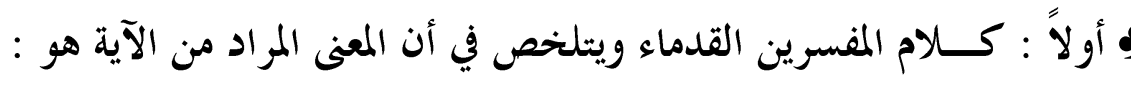

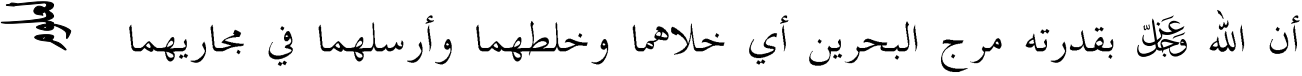

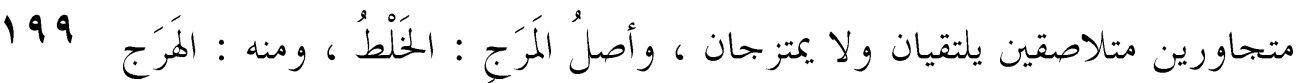

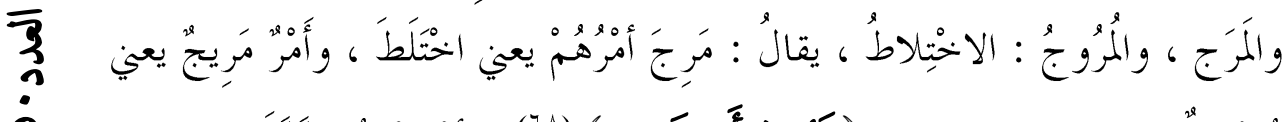

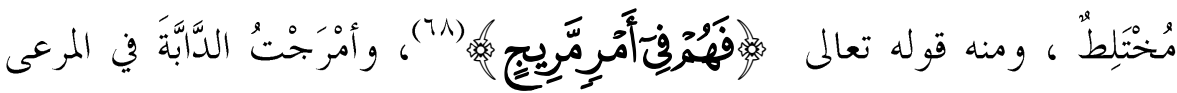

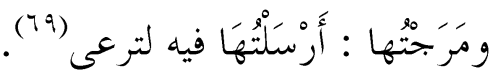

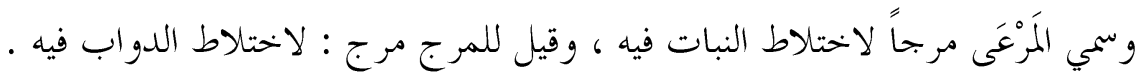

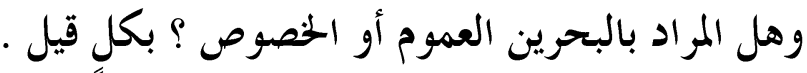

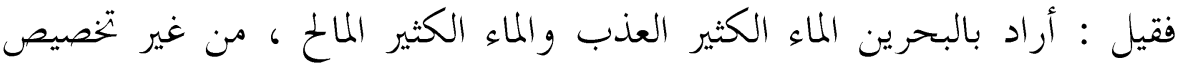

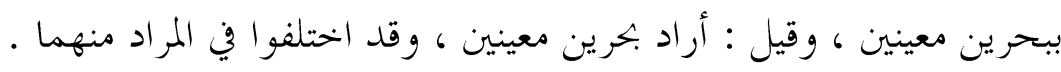

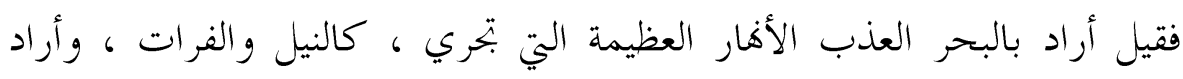

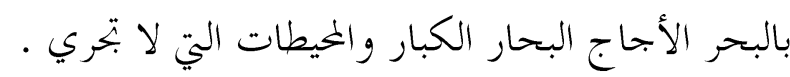

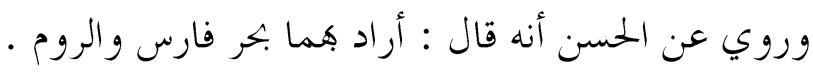

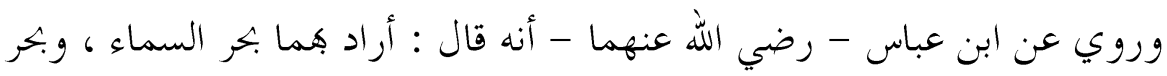


الأرض ، يلتقيان في كل عام (v•) ( هذا عذب فرات ) يعني شديد العذوبة بليغ الحلاوة ، قاطع للعطش من فرط

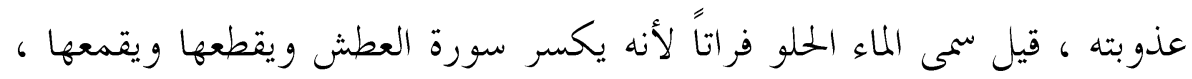

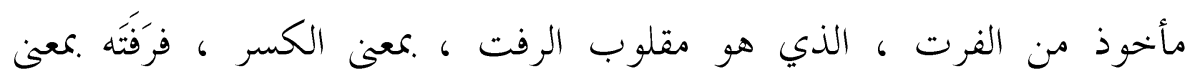

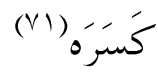

( وهذا ملح أجاج ) يعي بليغ الملوحة ، شديد المرارة ، فالأجاج نقيض الفرات . ( وجعل بينهما برزخاً ) أي هو سبحانه وتعالى جعل بين البحرين حائلاً ، فلا ألا يغلب أحدهما على الآخر ، و الأكثرون على أن البرزخ هو الحاجز المانع من قدرة

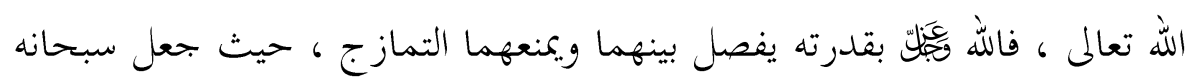

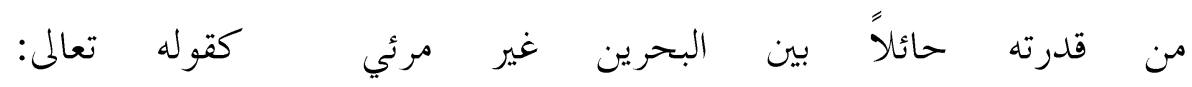
هو

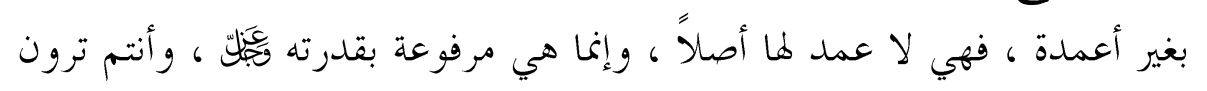

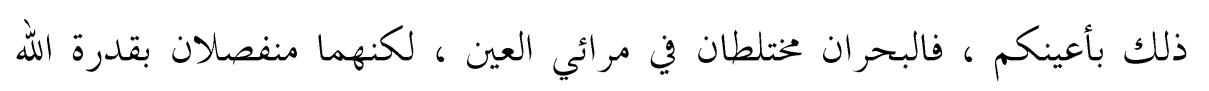
سبحانه . وذهب البعض إلى أن المراد من البرزخ ما بين البحرين من الأرض اليابسة ، أو

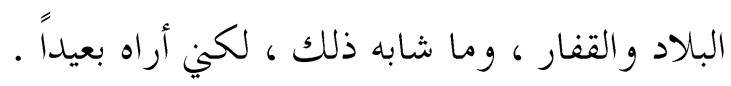

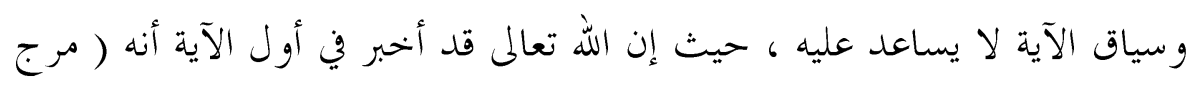
البحرين ) والمرج هو الخلط ، كما سبق بيانه ، فلو كان البرزخ بين البحرين أرضاً أو يبساً ، لم يكن هناك مرج للبحرين ، وإنما عرفنا قدرة الله تعالى بحجزه الملح الأجاج عن إفساد العذب الفرات ، مع اختلاط كل واحد منهما بصاحبه ، فأما

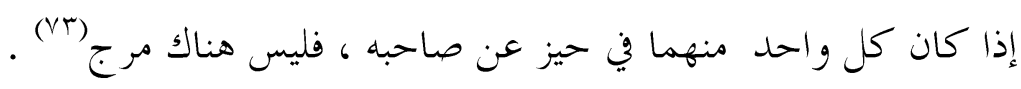
وذهب البعض إلى أن المراد بالبرزخ بين البحرين : الواسطة بينهما ، أي أن الله تعالى جعل بين البحر العذب الشديد العذوبة والبحر الملح الشديد الملوحة ماءً 


\section{الإعجاز العلمي في سورة الفرقان}

متوسطلً ليس بالشديد العذوبة ولا بالشديد الملوحة ، وهو قطعة من العذب الفرات عند موضع التلاقي ، مازجها شيء من الملح الأجاج ، فكسر سورة

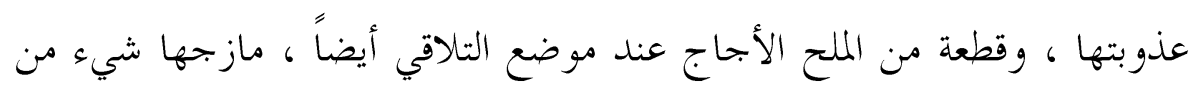
العذب الفرات ، فكسر سورة ملوحتها ، و ويكون التنافر البليغ بينهما المفهوم من

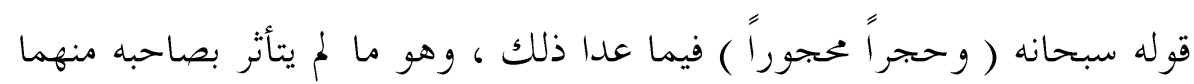
6 بل ييقى على صفته من العذوبة الشديدة و الملوحة الشديدة (ع لم) .

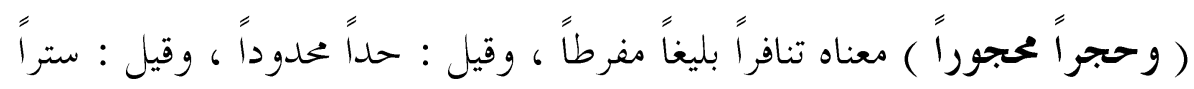

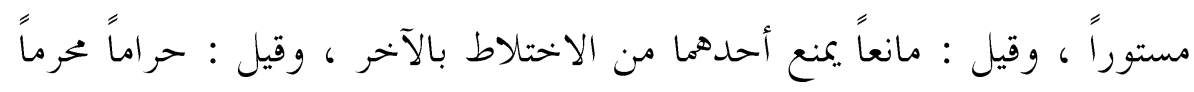
على صاحبه أن يفسده ويغيره ، وقيل : هي الكلمة التي يقولها المتعوِّذ .

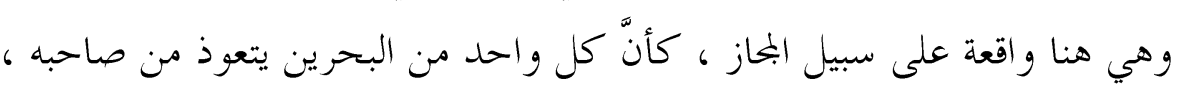

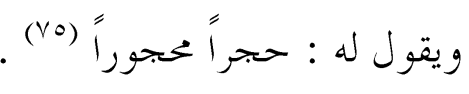

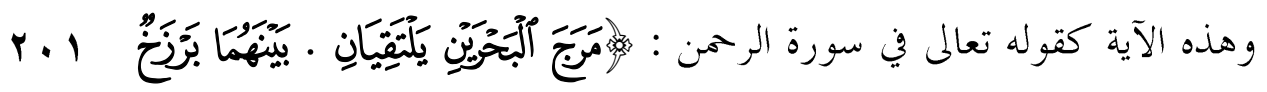

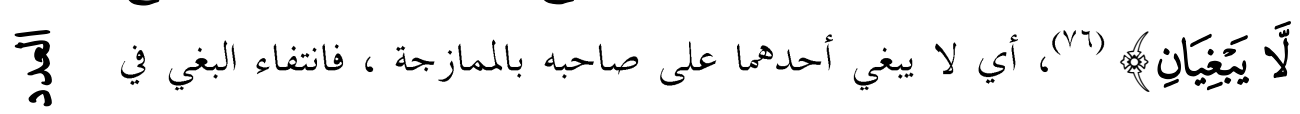
سورة الرحمن كالتعوذ في سورة الفرقان ، فجعل كل واحد منهما في صورة الباغي على صاحبه فهو يتعوذ منه ، وهي استعارة تمثيلية ، من أحسن الاستعارات 6 وأشهدها على البلاغة (VV).

دو وحاصل المعنى في الآية الكريمة أنه تعالى جعل البحرين مختلطين في مرأى العين ،

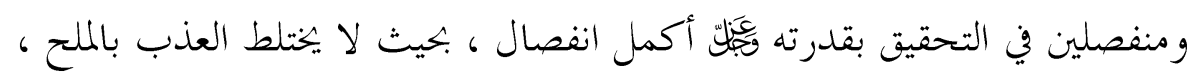
ولا الملح بالعذب ، و لا يتغير طعم كل منهما بالآخر أصلاً . و والمراد لزوم كل منهما لصفته من العذوبة والملوحة ، فلا يفسد العذبُ المالحً ولا المالحُ العذبَّ، ولا ينقلب البحر العذب ملحاً في مكانه ، وولا البحر الملح عذباً

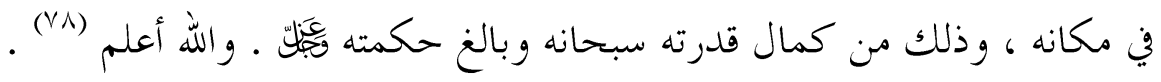
مه ثانياً : حقائق العلم الححديث ، وو جه الإعجاز في الآية : 
لقد أنبت العلم الحديث في الواقع المعاصر ، بما أضحى من الحقائق والمسلمات

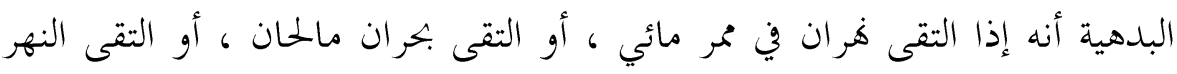

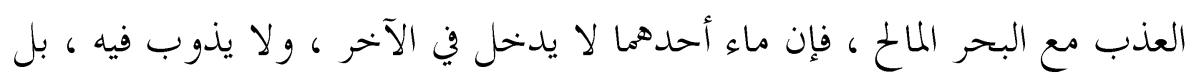

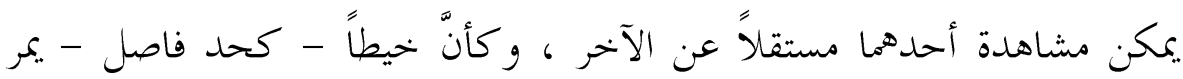

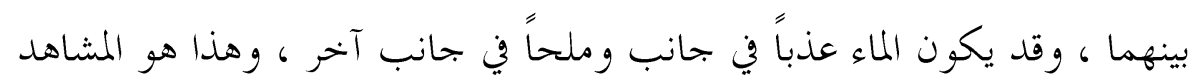

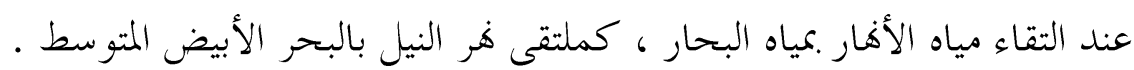

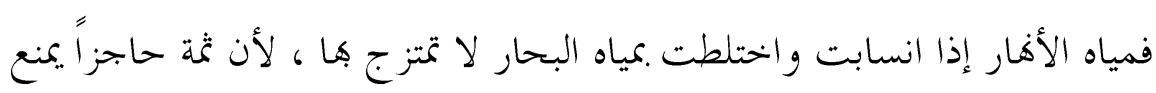
طغيان كل منهما على الأخرى . ويشير الدكتور زغلول النجار إلى تدفق النهر إلى البحر فيقول : ماء النهر

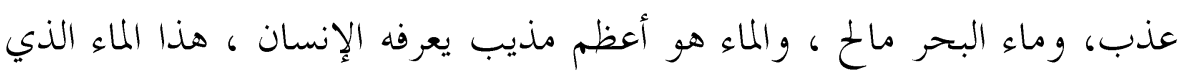

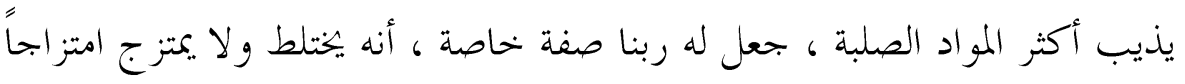

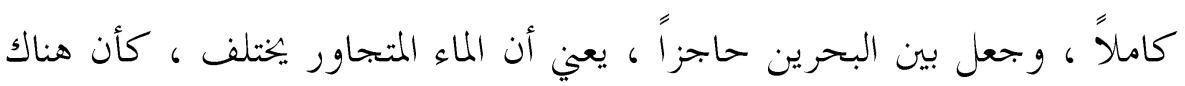

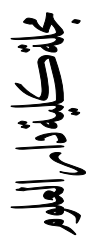

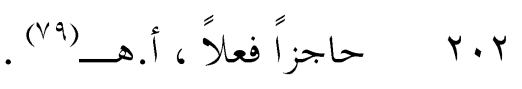

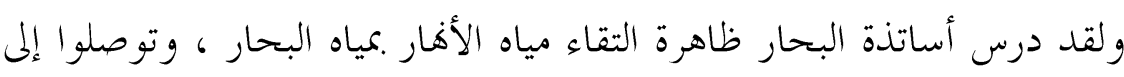

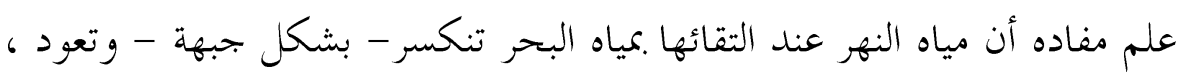

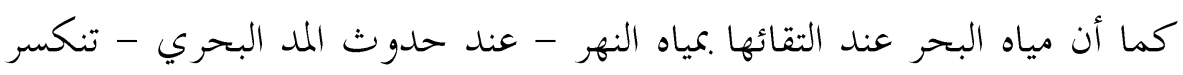

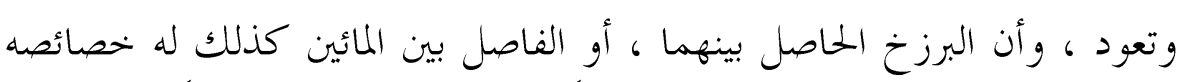

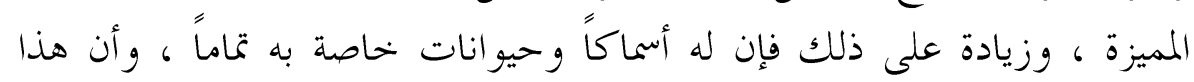

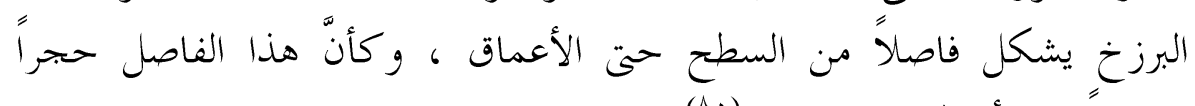

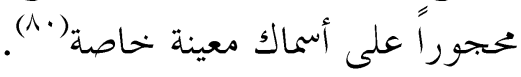

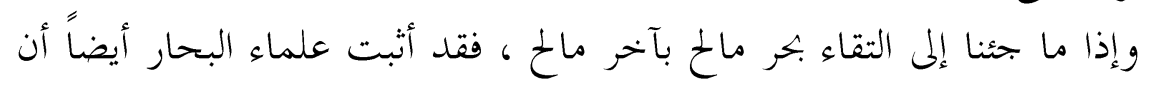

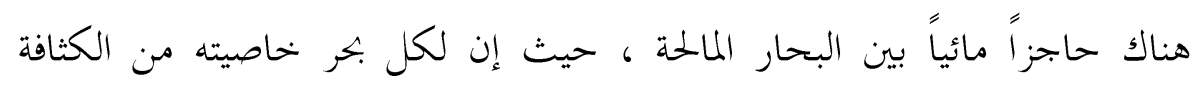

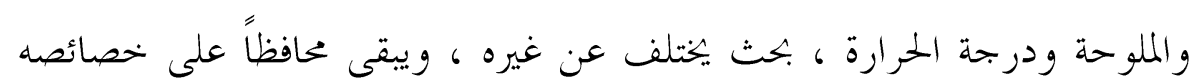

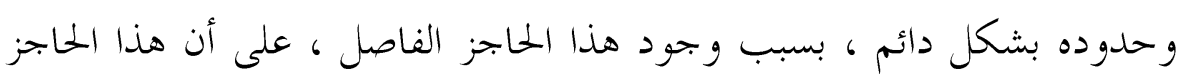




\section{الإعجاز العلمي في سورة الفرقان}

يغاير خاصية كل من البحرين ، بحيث يختلف بصفاته وأحيائه المائية ، وقابلية

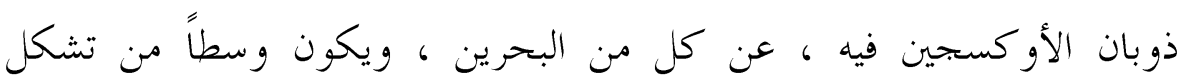

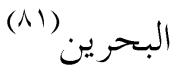

وهذا الحاجز يفصل بين كل بحرين ، بحيث لا يبغي أحدهما على الآخر بخصائصه

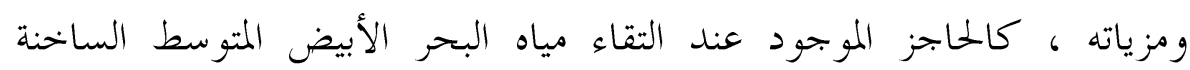

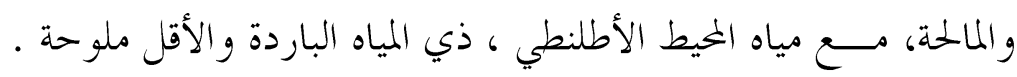
وقد ثبت أن امتزاج مياه البحار يتم عبر هذه الحو اجز المائية ، بطريقة بطيئة ،

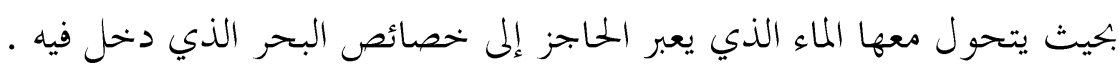

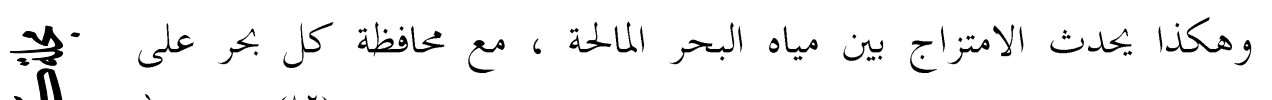

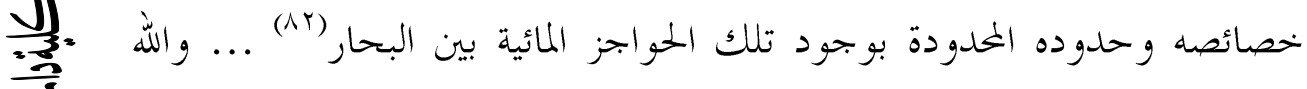

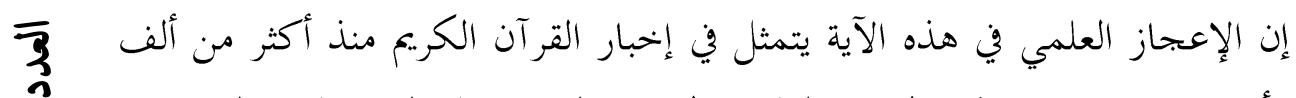

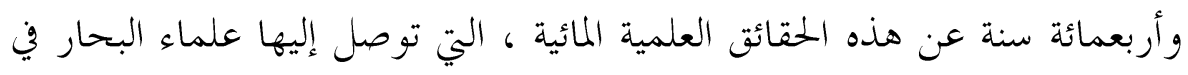

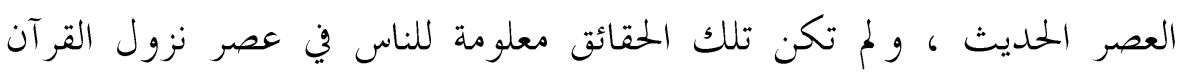

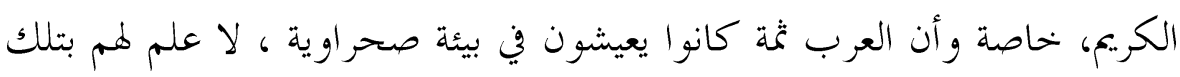

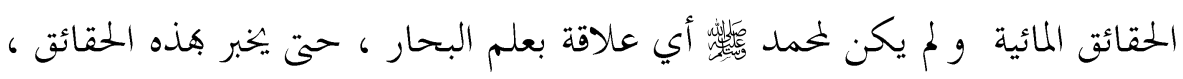

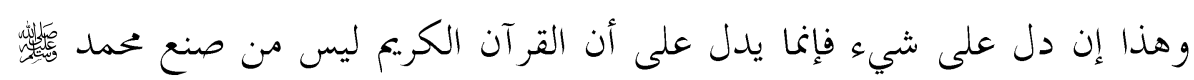

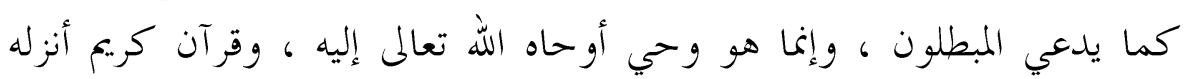

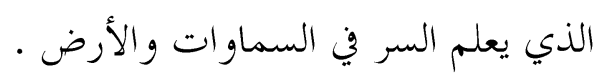

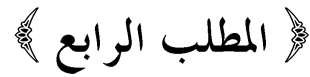

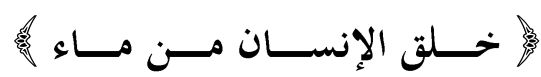




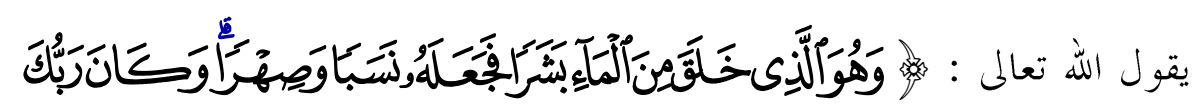

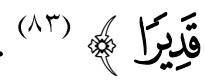

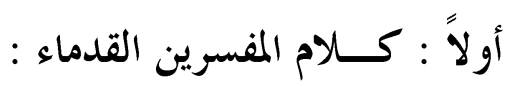

يتلخص كلام المفسرين القدماء في أن المعنى المراد من الآية الكريمة هو أن الله تعالى

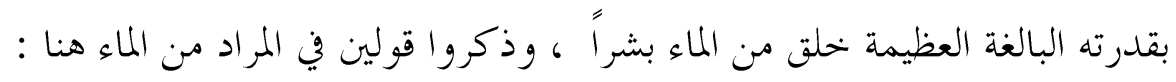

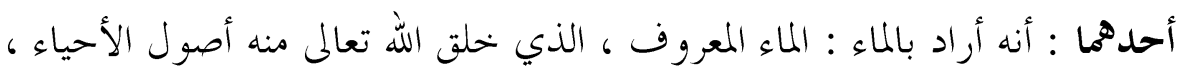
وهو المعنيّ بقوله تعالى :

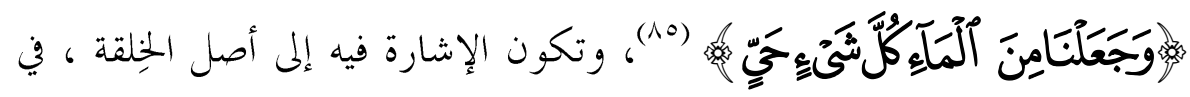

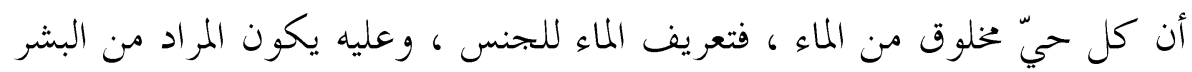

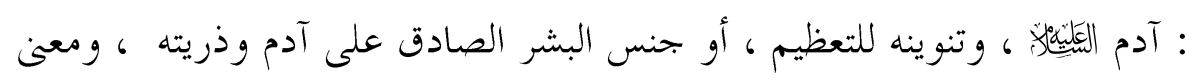

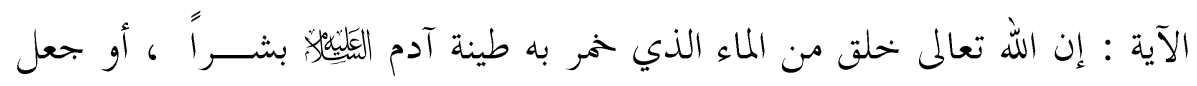

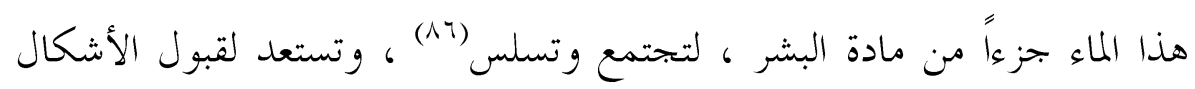
والهيئات بسهولة .

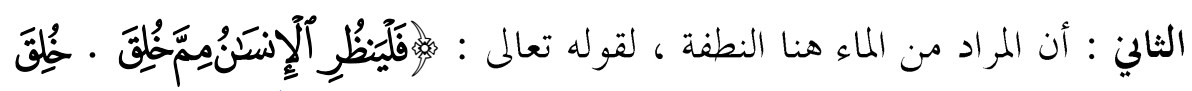
牙

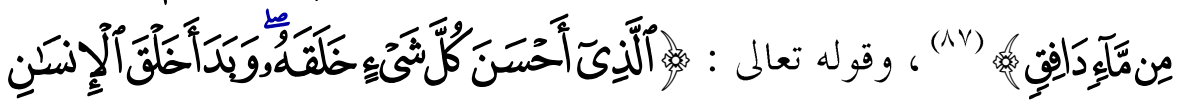

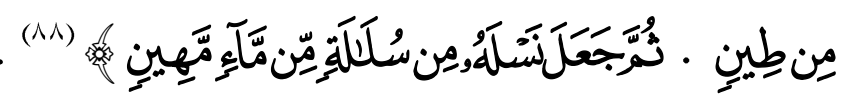

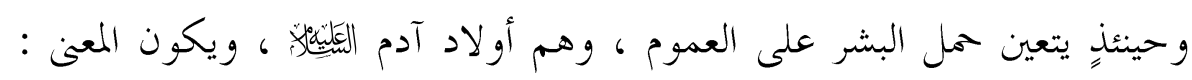

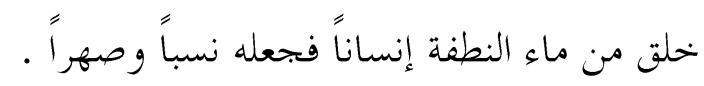
يد و الظاهر حمل الآية على العموم ، فيكون المراد من الماء : النطفة ، ومن البشر :

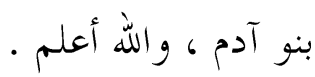

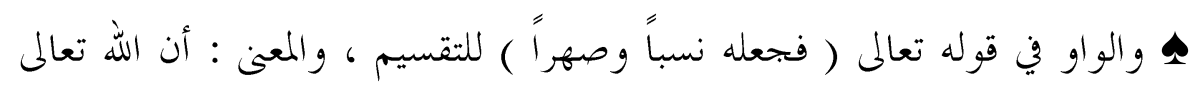

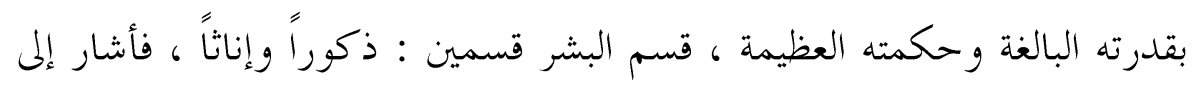




\section{الإعجاز العلمي في سورة الفرقان}

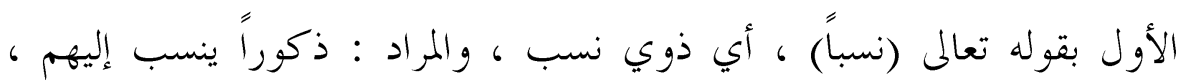
فيقال: فلان بن فلان وفلانة بنت فلان ، وأشار سبحانه إلى الثاني بقوله :

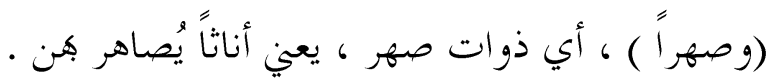

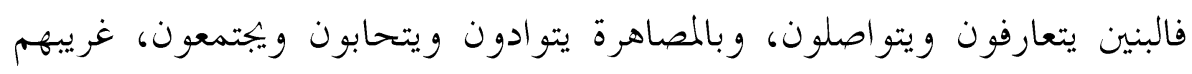
وقريبهم .

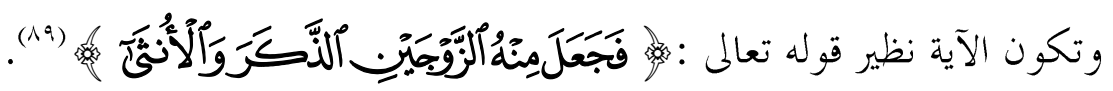

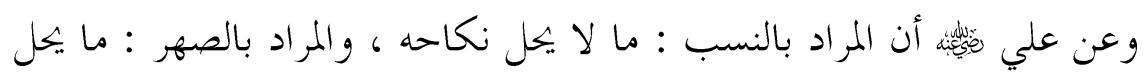

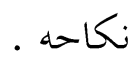

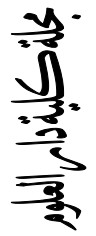

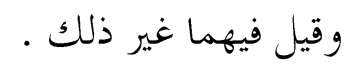

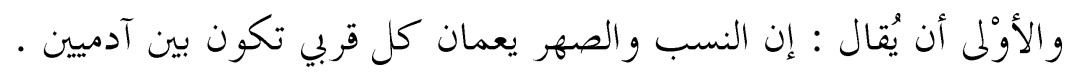

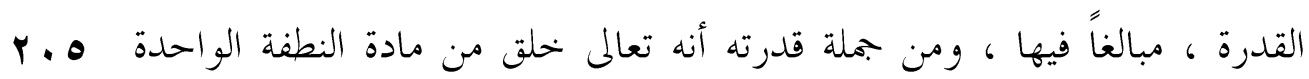

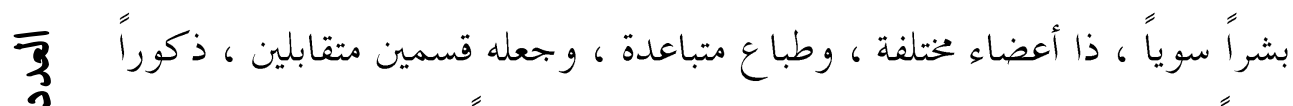

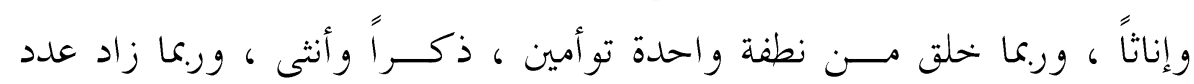

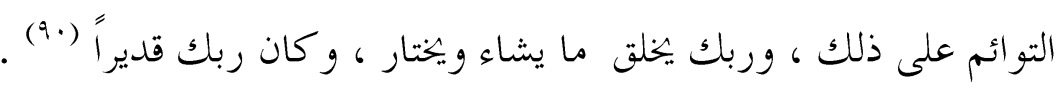
مه ثانياً : حقائق العلم الحديث ، ولث ، ورجه الإعجاز في الآية :

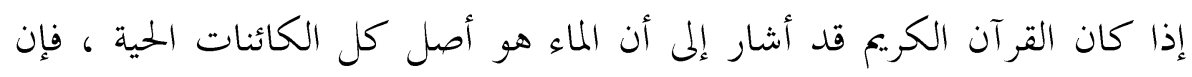

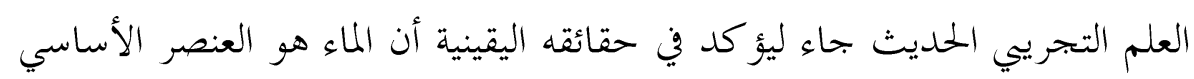
واللازم لأيّ حياة. . يقول الدكتور موريس بو كاي تحت عنوان ( أصل الحياة ) ، وتعليقاً على قوله

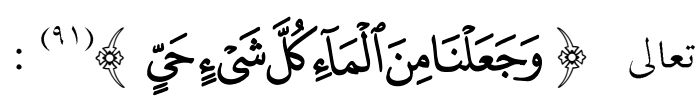
ليس هناك شك في مفهوم المصدر ، فالعبارة همكن أن تعني أن كل شيء مصاد مصدره

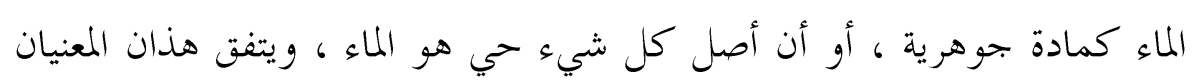


تماماً مع الحقائق العلمية ، فالثابت بالتحديد أن أصل الحياة مائي ، وأن الماء هو

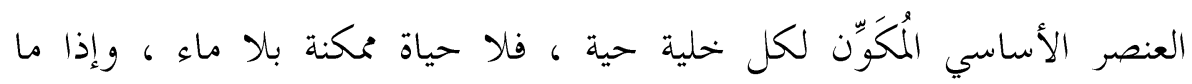

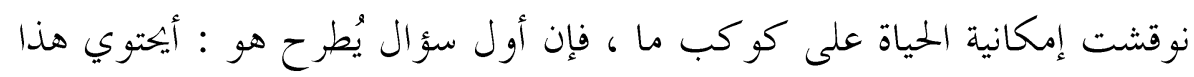

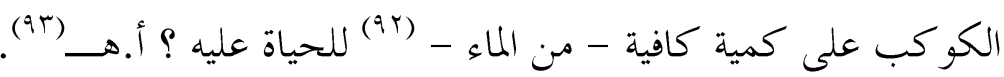

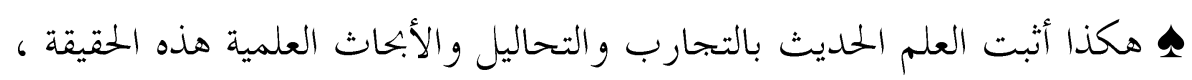

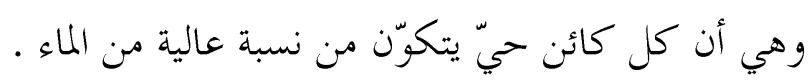

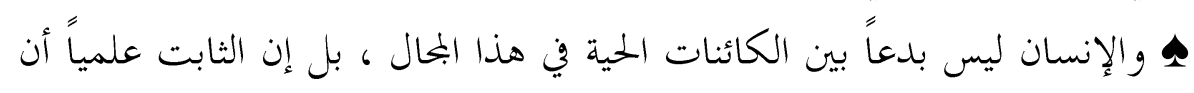

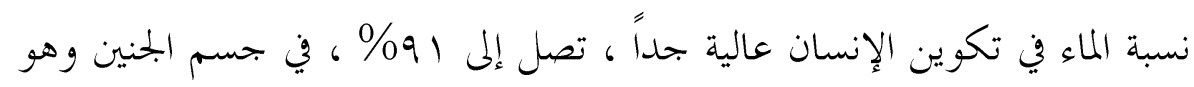

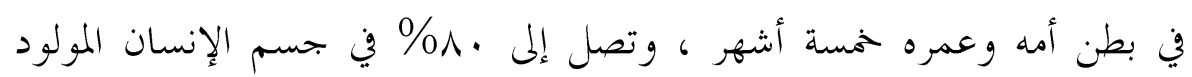

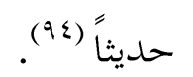

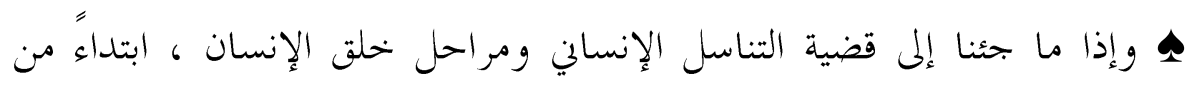

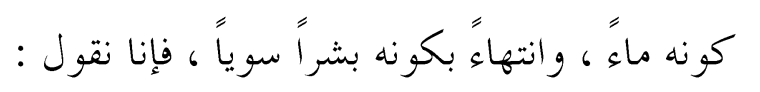
势

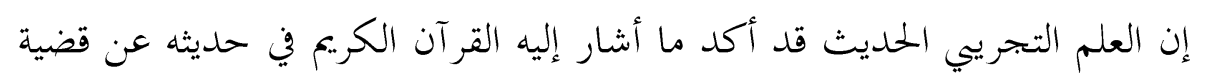
r. التناسل الإنساني . لقد وضح القرآن الكريم تلك القضية أبمل توضيح ، وبيَّنَ تلك المراحل أعظم

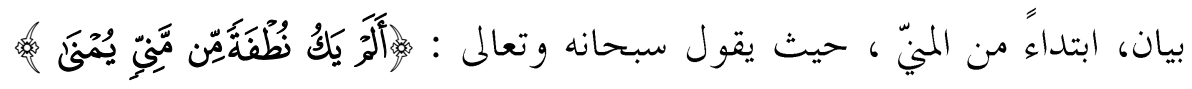

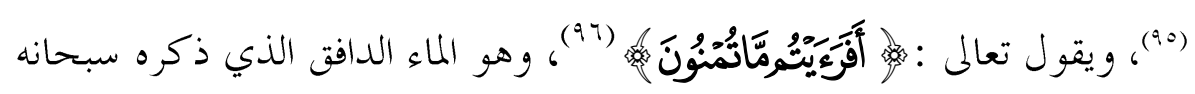

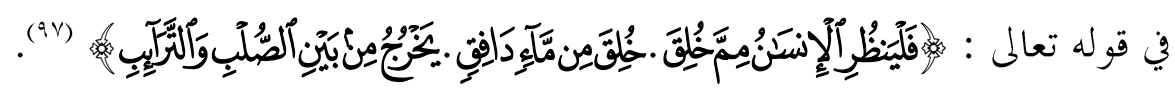

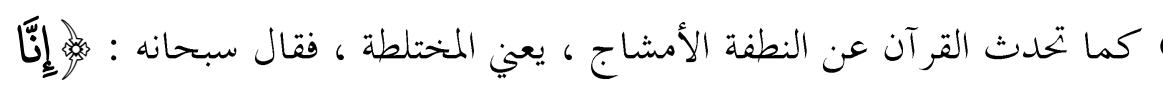

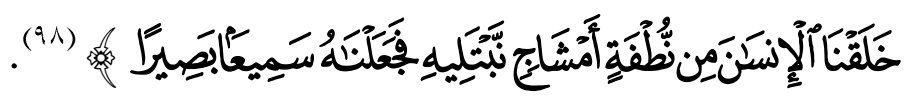

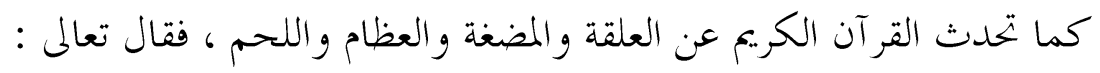

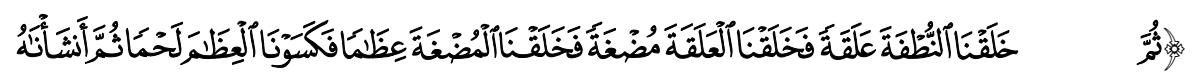

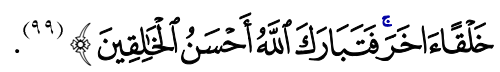




\section{الإعجاز العلمي في سورة الفرقان}

هـ وهذا ما أكده العلم الحديث ، الذي وضح لنا أن التناسل البشري مكفول

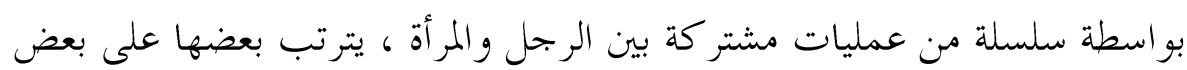

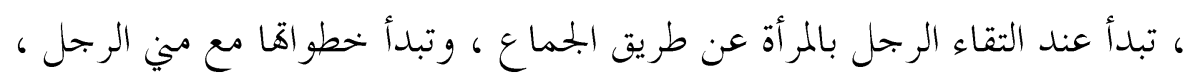

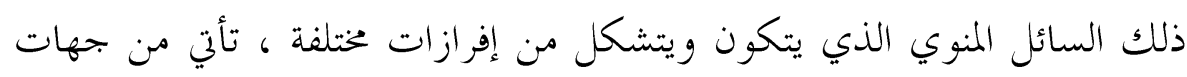

$$
\text { 1- الحخديتان ، هي : }
$$

حيث يحتوي إفراز الغدة التناسلية للذكر على الحيوانات المنوية ، وهي خلايا

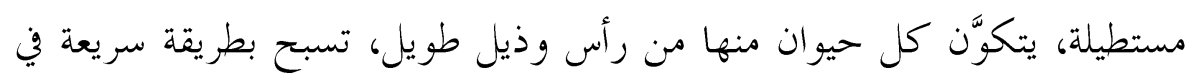

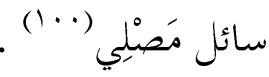

$$
\begin{aligned}
& \text { r ب الحويصلات المنوية . }
\end{aligned}
$$

$r \cdot v$

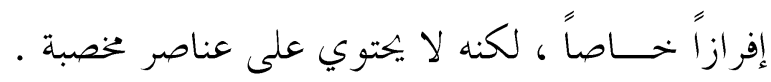

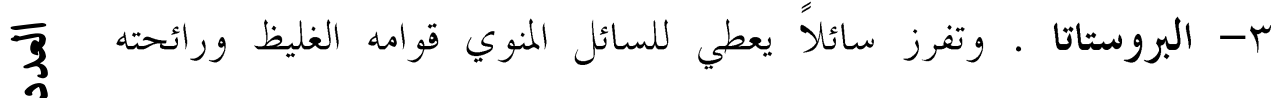
الخاصة.

ع - الغدد الملحقة بالمسالك البولية .

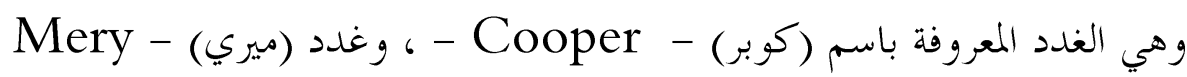

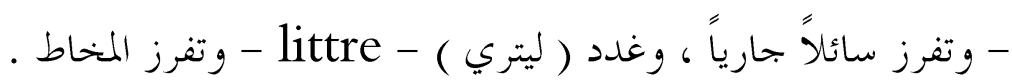

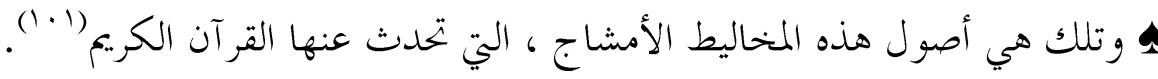

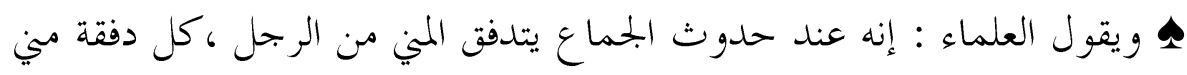

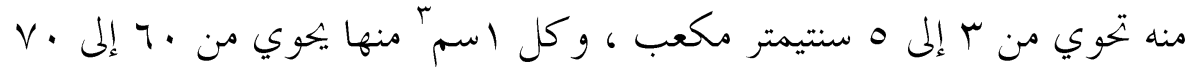

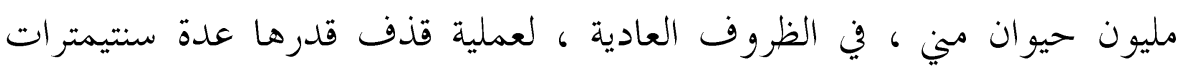

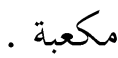


تم يبدأ السباق الكبير بين هذا العدد الهائل من الحيوانات المنوية ، و الذي يكون

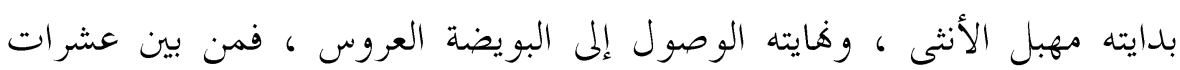

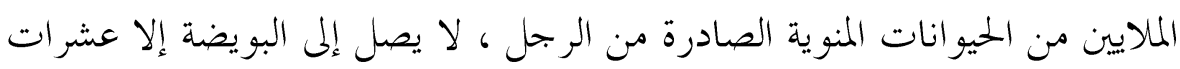
الحيوانات فقط ، ثم إنه لا يصل إلى البويضة ويفوز بالولوج فيها إلا حيوان واحد فقط (r.1) ، هو الذي يستطيع أن يخترق جدار البويضة الشفاف من موضع معين ويتم تلقيح البويضة في الثلث الأخير من البوق .

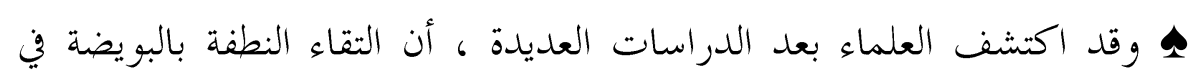
الثلث الأخير لقناة الرحم - قناة فالوب - شرط أساسي لحصول التزاوج بينهما ، أي أن المكان الوحيد الذي هيأه الله تعالى وأعده بقدرته وعلمه وحكمته ، لإقامة مراسم العرس والتزاوج بين النطفة والبويضة هو مكان وحيد ومخصوص ، وله وهو

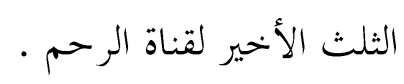
ولا ننسى أن نذكر حقيقة علمية أخرى في سباق الحيوانات المنوية ، وهي أهنا 牙 حين تدخل جوف الرحم ، لا تدخل إلا إلى البوق الذي يحوي البويضة ولا تدخل $r \cdot \wedge$

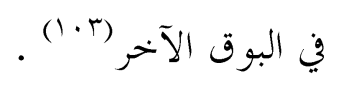

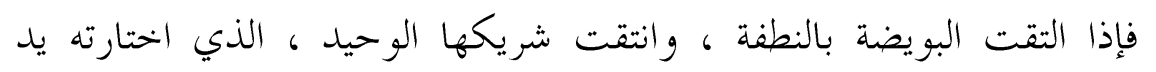
القدرة الإلهية ، من ملايين الحيوانات المنوية ، تتزل البويضة - بعد التخصيب لتعشش في التجويف الرحمي ، وهو ما يسمى بـــ ( تعشش البويضة ) ، و الذي تهي

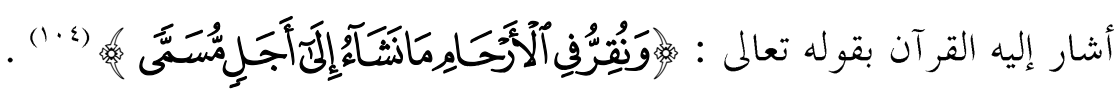

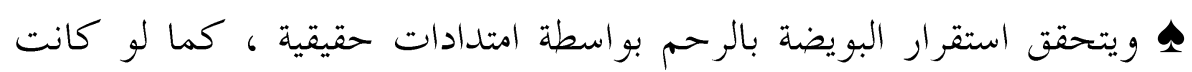

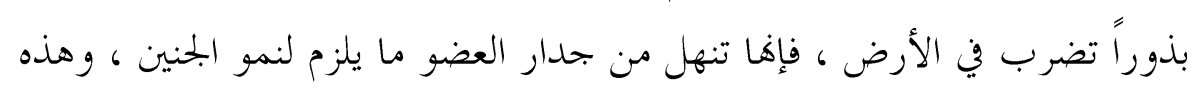

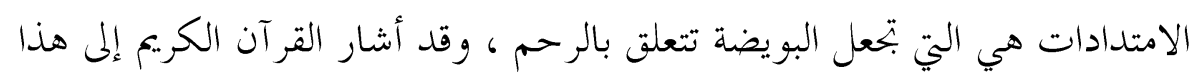

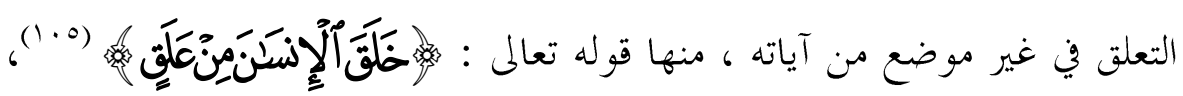

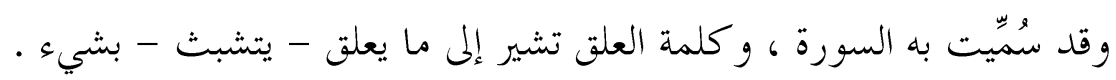




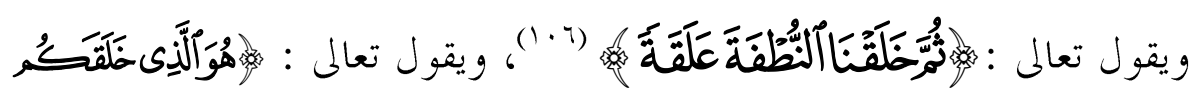

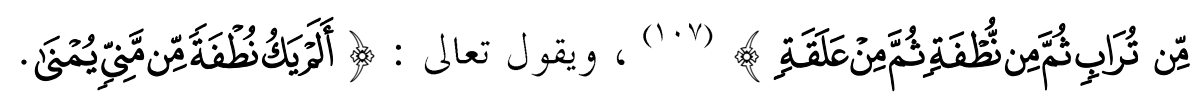
(1) (1)

ه بعد مرحلة التشبث هذه في الرحم ، يتطور الجنين حتى يصير كتلة صغيرة ،

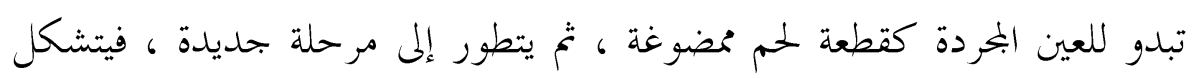

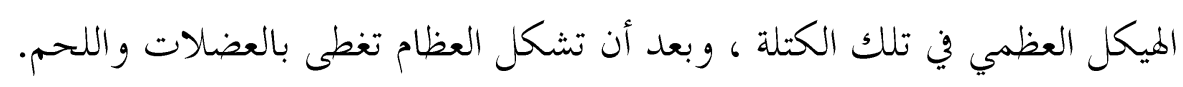

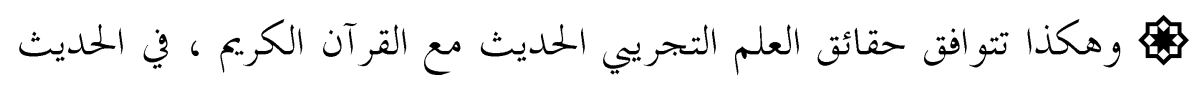

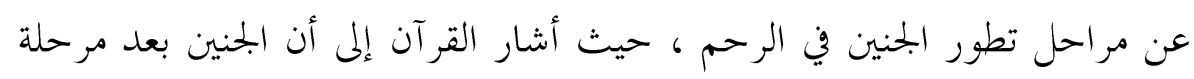

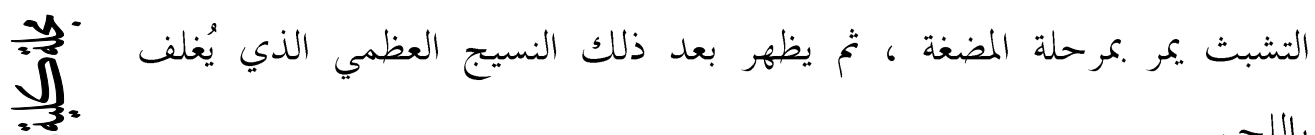

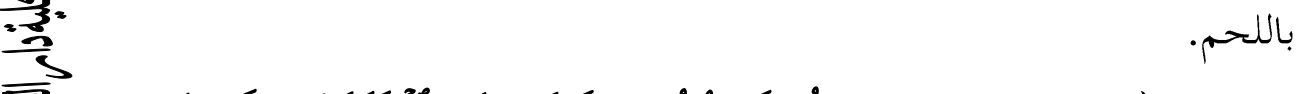

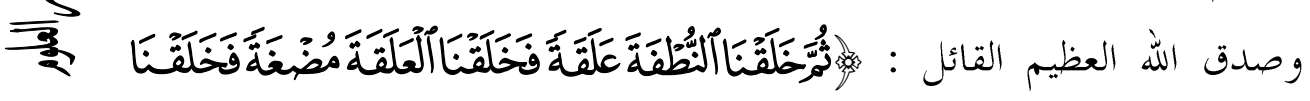

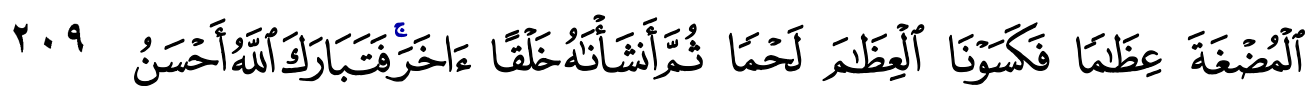
$\bar{s}$

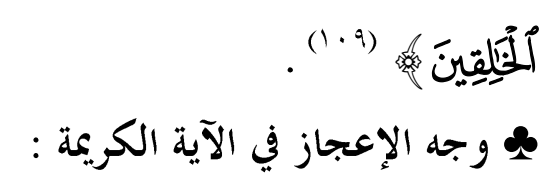

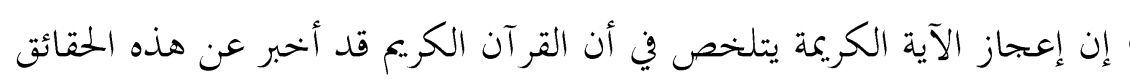

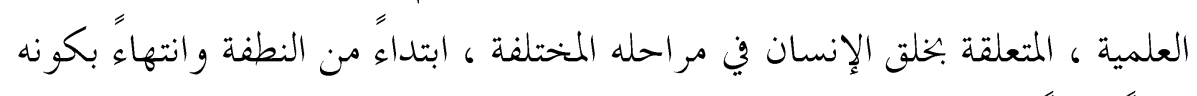

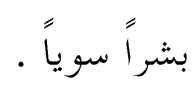
وليس هناك أدنى شك في أن المعاصرين لنزول القر آن الكريم لم يعرفوا شيئاً عن

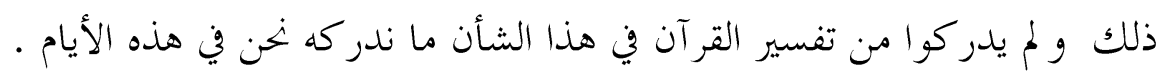

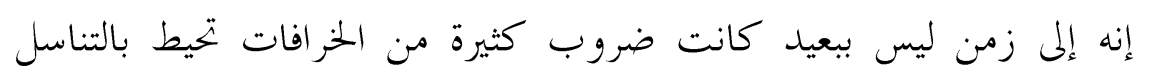

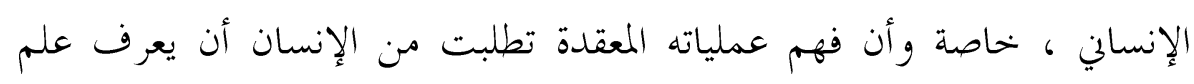

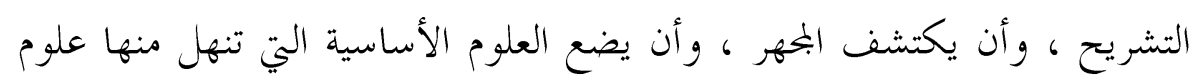
وظائف الأعضاء والأجنة والتو الد ، وغير ذلك وأن بضع العلى ل 
لكن الأمر مختلف تماماً بالنسبة إلى القرآن ، فهو يذكر في مواضع عديدة

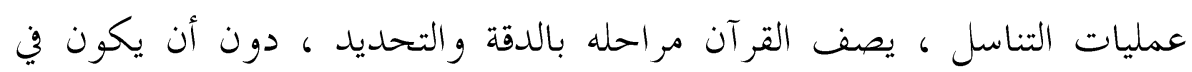
قراءها أي مقولة مشوبة بالخطأ ، إنه يعبر عن ذلك في عبارات بسيطة ، يسهل

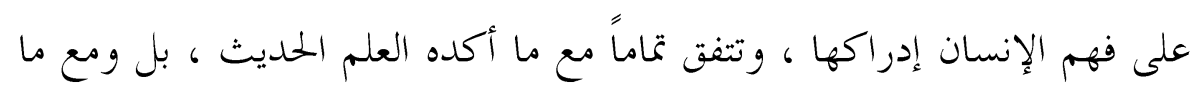
سيكتشف بعد ذلك بكثير (11.) أرأيت أخي الكريم كيف كان من المناسب أن تختم آية الفرقان التي معنا بقوله

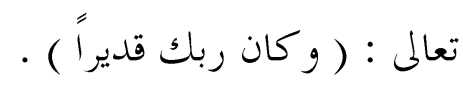

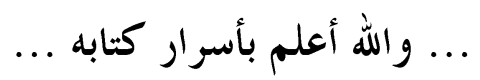

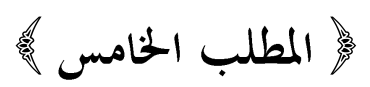

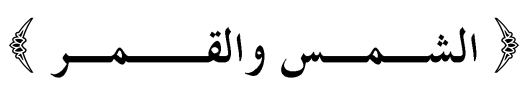

يقول اللهّ تعالى :

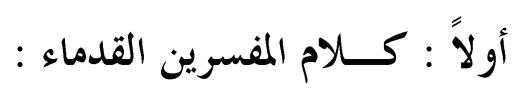

يتلخص كلام المفسرين القدماء في أن المعنى المراد من الآية الكريمة هو أن الله لِيَّلَّل

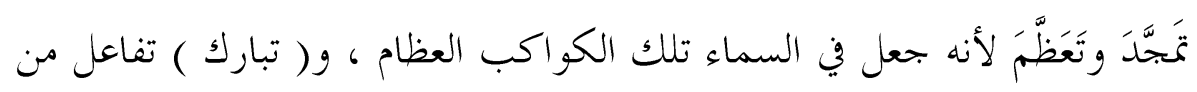

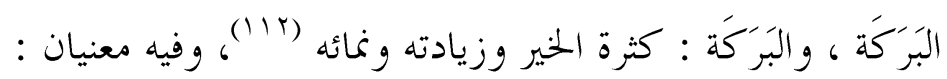

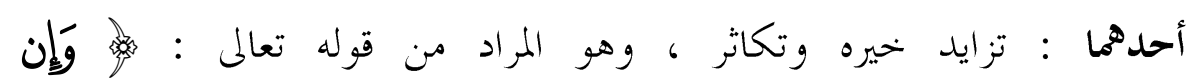

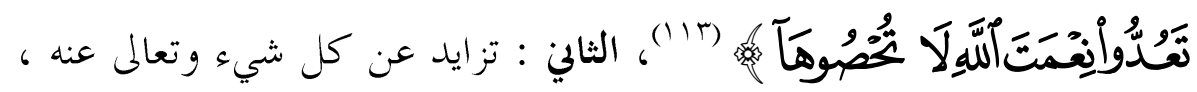

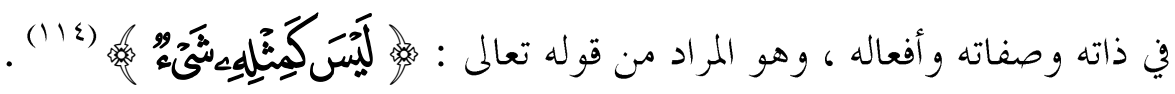

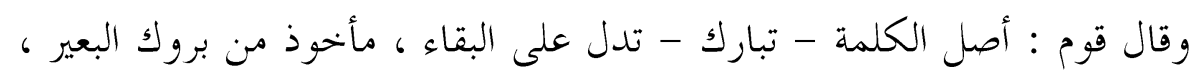

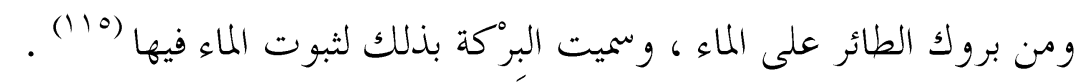

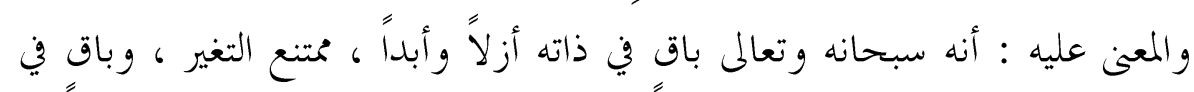

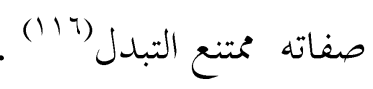


و الظاهر أن المر اد بالسماء : السماء الدنيا ، لأها المعروفة ، ولأن البروج فيها ،

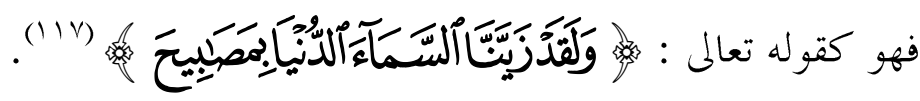

و البروج : جمع برج ، وأصل معنى البرج : الأمر الظاهر ، مأخوذ من التبرج ،

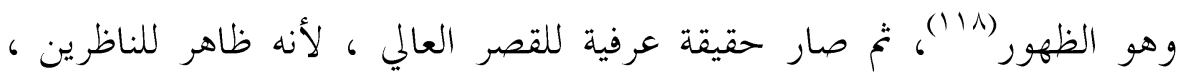

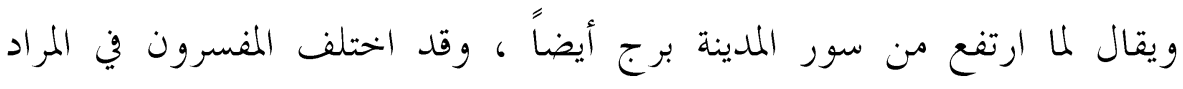

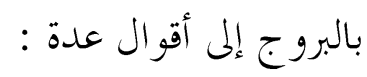

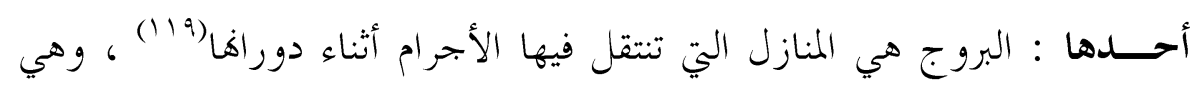

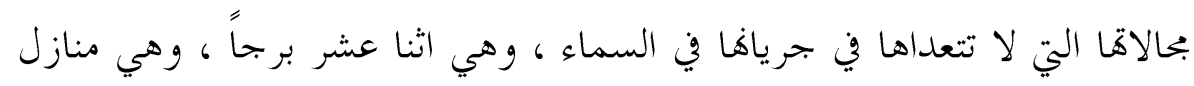

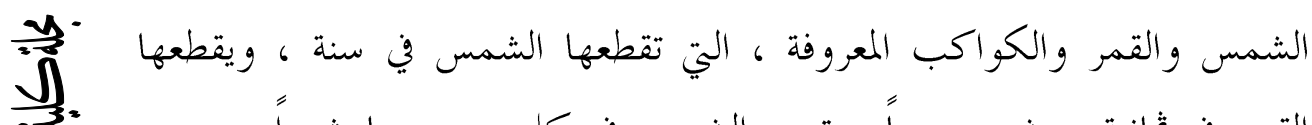

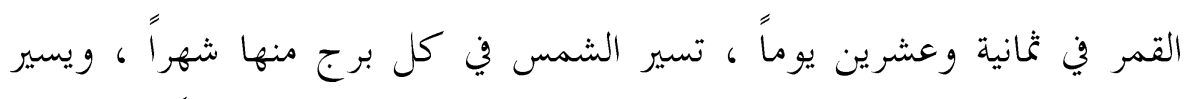

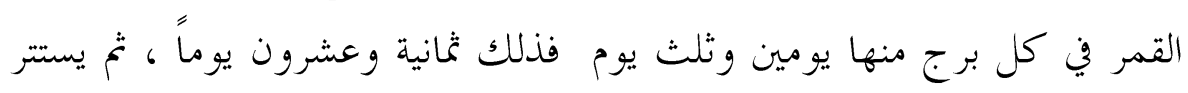

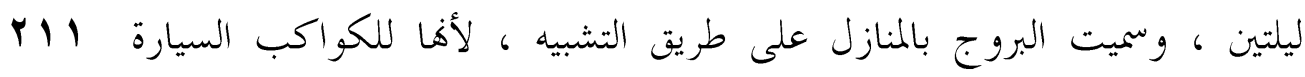

$\overline{3}$ كالمنازل الرفيعة لسكاها .

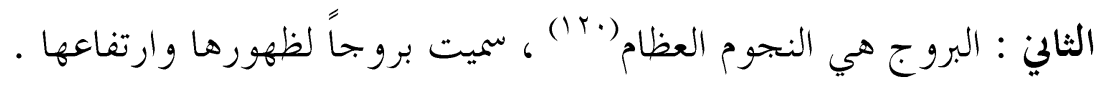

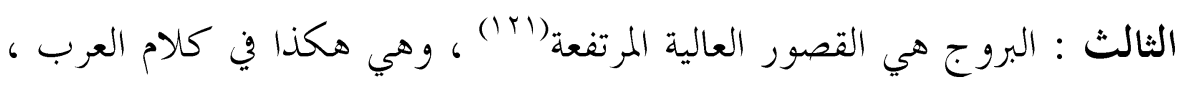

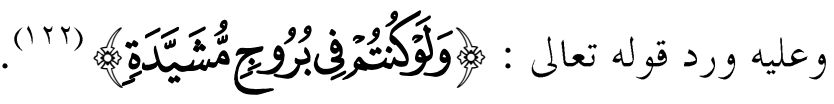

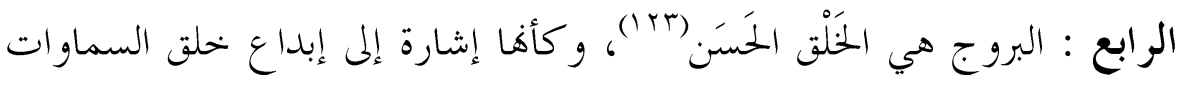

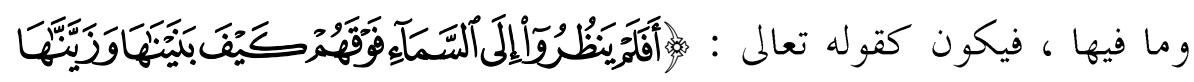

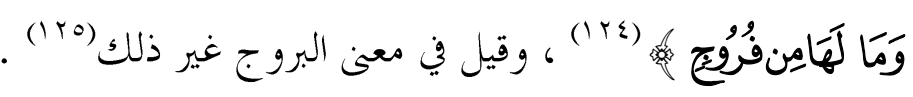

والظاهر أن المراد بالبروج : منازل الكواكب السيارة ، ومداراتا الفلكية

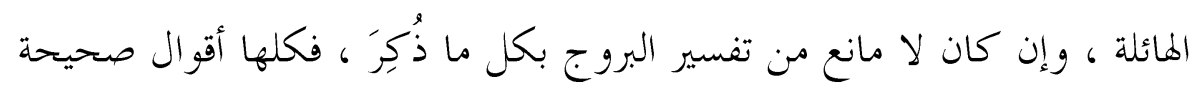

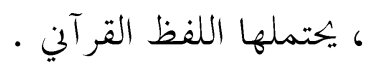


فقد أحسن الله تبارك وتعالى خلق السماوات وما فيها ، وزينها بالنجوم والكواكب التي شُبِّهَت في علوها وارتفاعها بالقصور العالية ، وجعل الله تعالى في ونسي السماء لتلك النجوم منازل تسكنها وبتري فيها لا تتعداها ، يقول سبحانه :

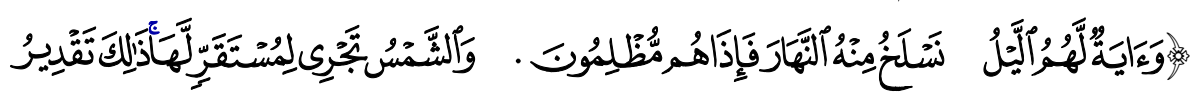

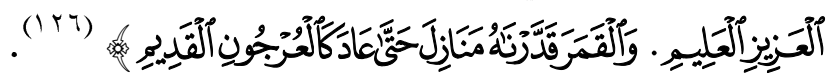

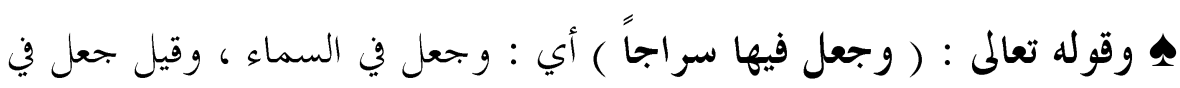

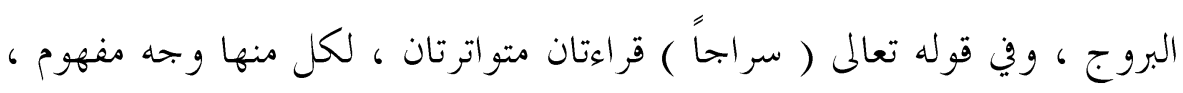

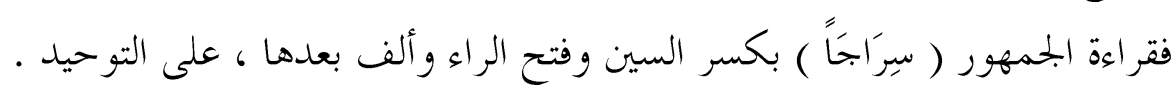

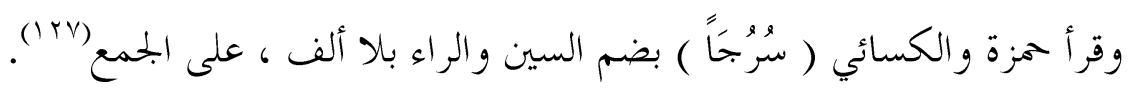

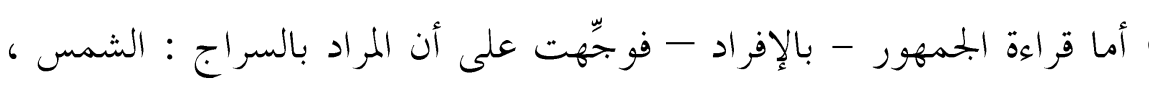

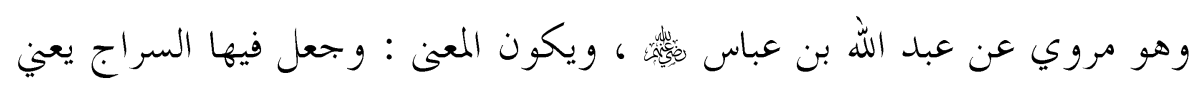

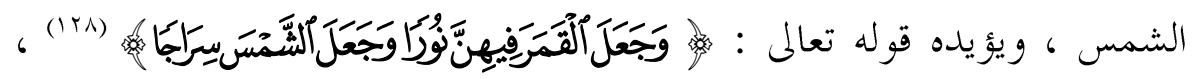

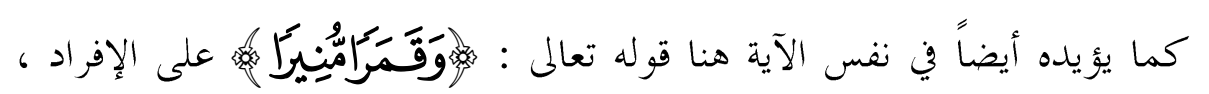

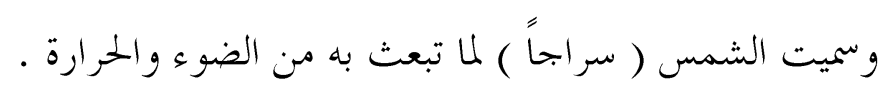

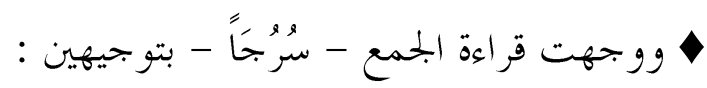

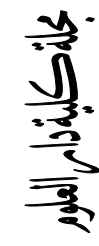

rIT

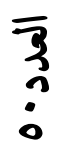

الأول : أن الجمع على ظاهره ، وأنه أراد كل ما أسرج وأضاء ، فيكون المراد

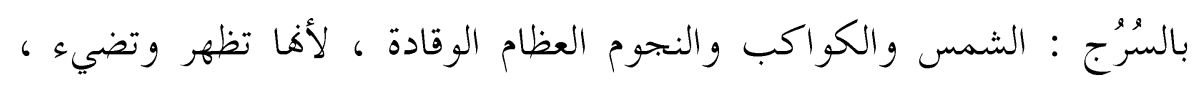

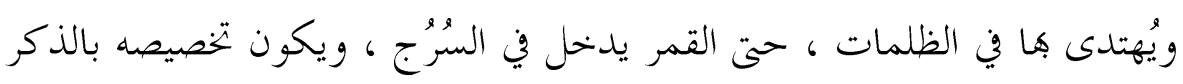

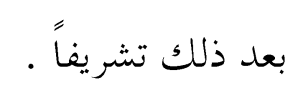
الثالي : أن الجمع ليس على ظاهره ، بل إنه أراد بالسرُج أيضاً الشمس وحدها ،

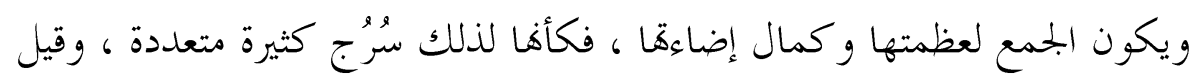

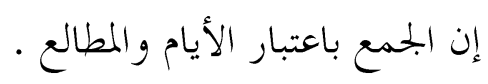
وعلى هذا التوجيه الثاني تتحد قراءة الجمع مع قراءة الإفراد . 


\section{الإعجاز العلمي في سورة الفرقان}

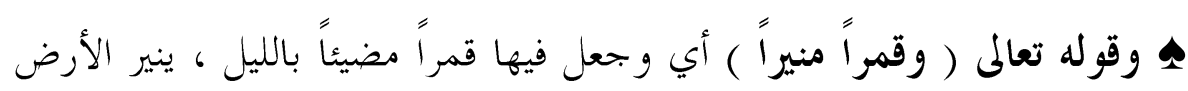

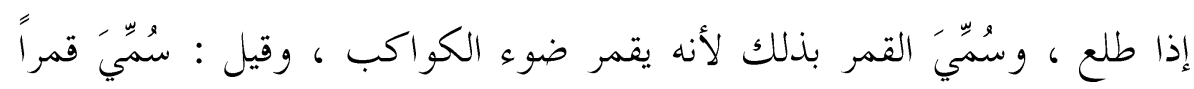

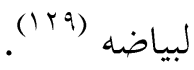

و ولم يبعل القمر سراجاً كالشمس ، لأنه لا توقد له ، وإنما يأني بنوره المادي

اللطيف والمعنى : وجعل فيها الشمس المتوقدة بالنهار والقمر المضيء بالليل .

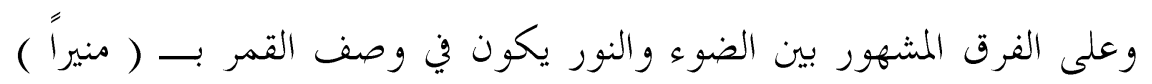

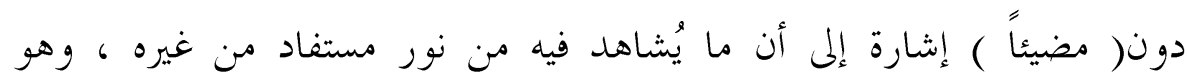

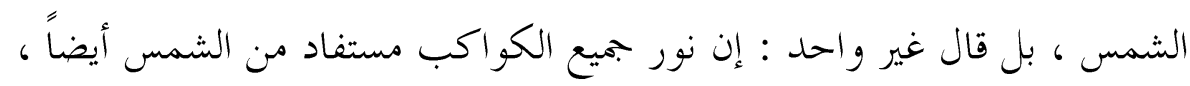

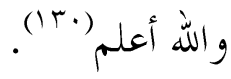

مُ ثانياً : حقائق العلم الحديث ، و ووجه الإعجاز في الآية :

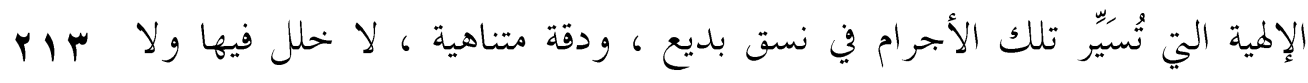
$\bar{\vdots}$ اضطر اب أب وفيما يتعلق بالشمس والقمر بنحد القرآن الكريم في حديثه عنهما قد حدد الفرق

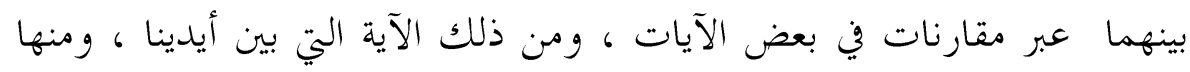

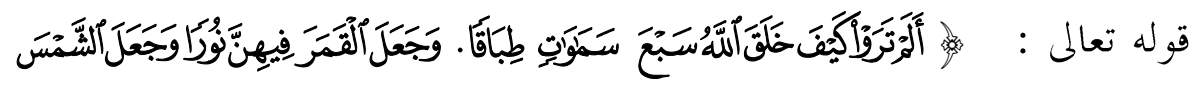
(1) وغالباً ما يُوصف القمر في القــرآن بالنور ، وتوصف الشــمس بالضياء أو بالسراج و بالتأكيد كان الإنسان في عصر نزول القرآن يستطيع التفريق بين السراج

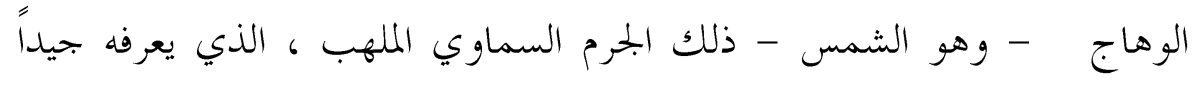
سكان الصحراء، و وبين القمر الذي هو جرم طراوة الليالي . 
وفرق في المعنى بين الضياء والنور ، لأن الضوء خلاف النور ، فالضوء فيه

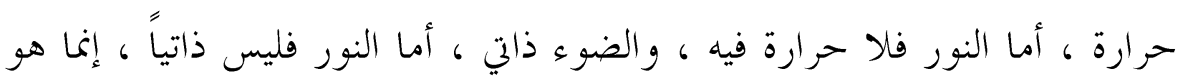
مكتسب من غيره ، متولد من وقوع الضوء على الأجسام ، فالضياء هو الذي ينبثق مباشرة من جسم مشتعل مضيء بذاته ، وحين يسقط هذا الضياء على جسم معتم ينعكس نوراً.

و وذذا ما أكده العلم التجريي في العصر الحديث ، فحقائق العلم تؤ كد أن القمر بأن ليس مضيئاً بذاته ، بل هو كو كب خامل ، و وجسم معتم يعكس الضوء الذي

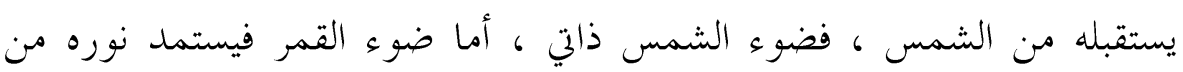

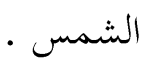

ولذلك وصف القرآن القمر بأنه منير ، و لم يصفه بأنه مضيء ، هذا التفريق

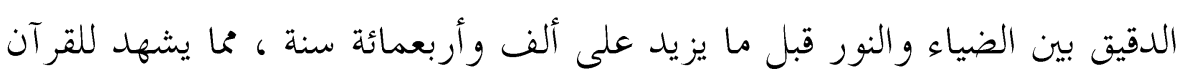

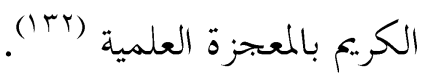

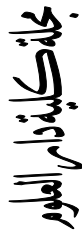

و وإذا كان القرآن الكريم في حديثه عن الشمس والقمر توقف عند الإشارات ए। العلمية ، فقد جاء العلم التجريي الحديث بتفسير تلك الإشارات ، وأكتفي هنا بما ذكره الدكتور موريس بو كاي في كتابه القيم ( القرآن الكريم والتوراة والإنجيل

$$
\text { و والعلم ) ، ففيما ذكره غنية ، حيث قال : }
$$

ما يفسر هنا بمدار هو ( فلك ) في نص القرآن ، وهي كلمة عربية قديمة ، ولقد

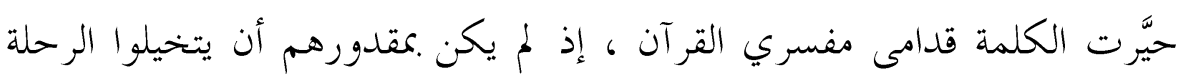
الدائرية للشمس والقمر في الفضاء. وعليه فقد تمثلوا - عند مسيرتي هذين الجرمين - صوراً مغلوطة تماماً ، أو على في لفئ درجات نختلفة من الصحة . 


\section{الإعجاز العلمي في سورة الفرقان}

ذلك يوضح لنا إلى أيّ حد كان الناس عاجزين عن تمثل فكرة المدار الشمسي والمدار القمري ، ويتضح من هذا أنه إذا كانت كلمة ( فلك ) تعني مفهوماً سائداً

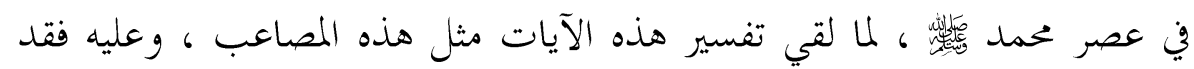

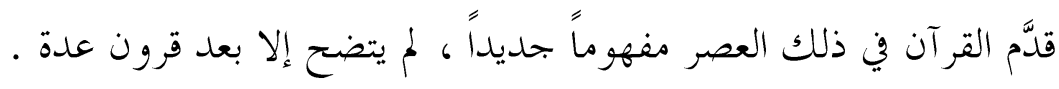

الإشارة إلى تنقل القمر والثمس في الفضاء بحر كة خاصة :

يؤدي القمر دورته حول نفسه في نفس الوقت الذي يتم فيه دورته حول الأرض ،

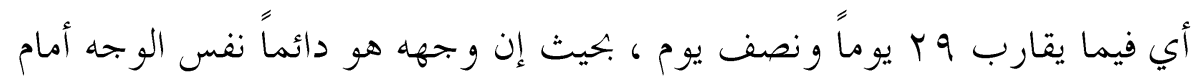

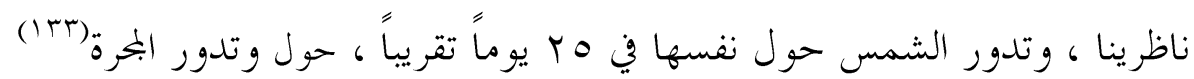

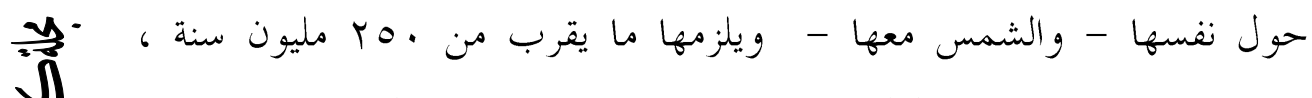

等 وتسير الشمس في هذه الحركة بسرعة تقريبية قدرها . • ب كيلومتر في الثانية

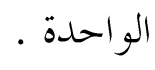

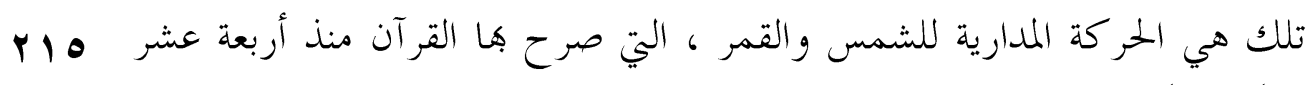

قرناً تقريباً ، إن وجود هذه الحر كة وعلامتها هي الآن من مكتشفات علم الفلك

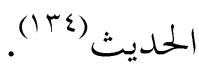

\section{مُ وجه الإعجاز في الآية الكريمة :}

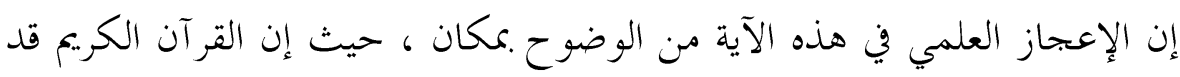

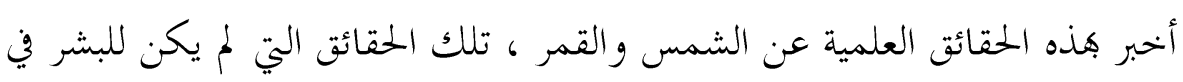
عصر نزول القر آن معرفة ها ، و لم يكتشفها الإنسان إلا في هذا العصر الحديث .

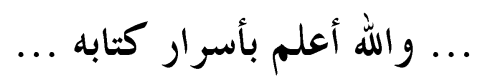

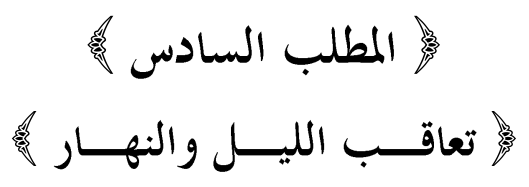




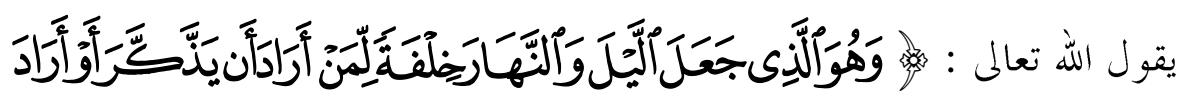

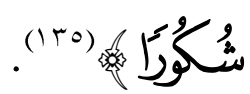

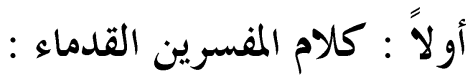

يتلخص كلام المفسرين القدماء في أن المعنى المراد من الآية الكريمة هو أن الله لئلئل

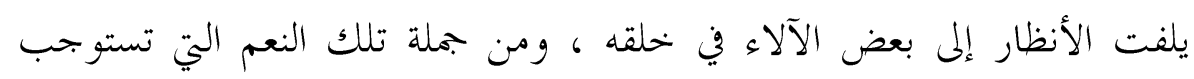

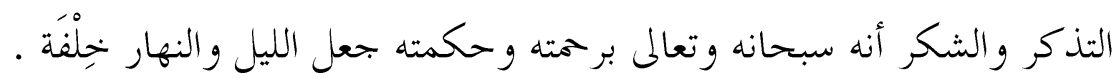

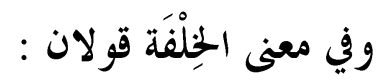

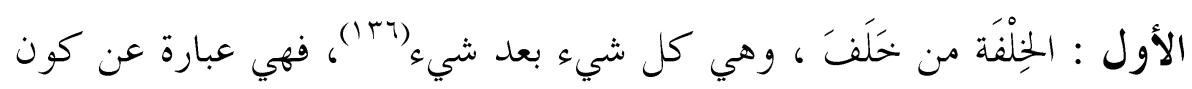

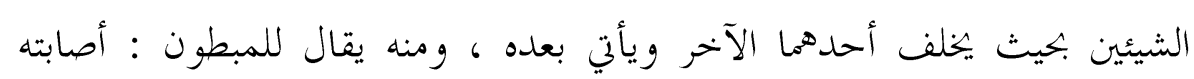

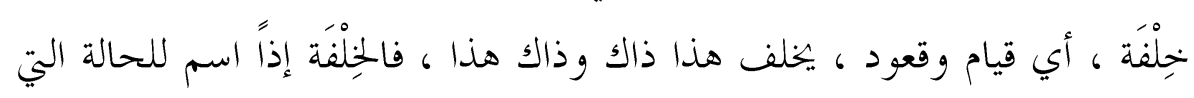

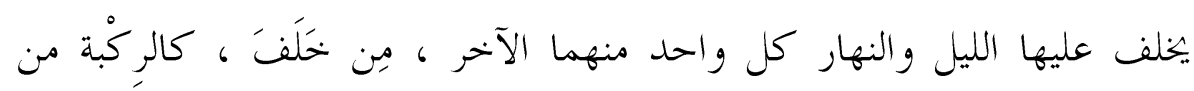

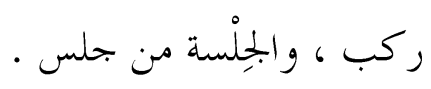

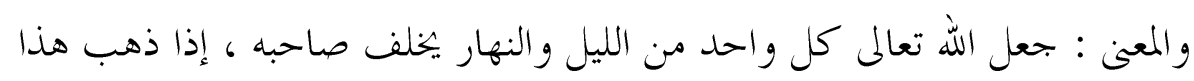

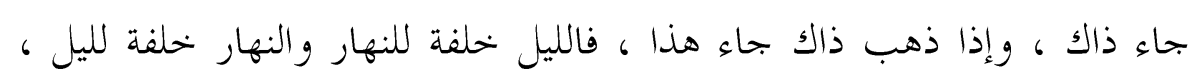

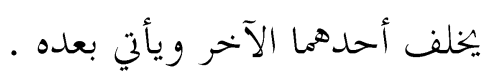

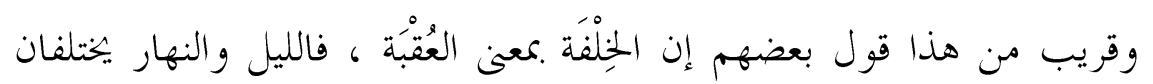

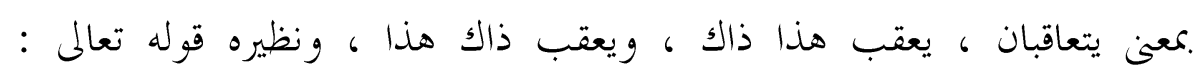

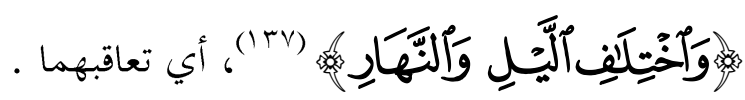

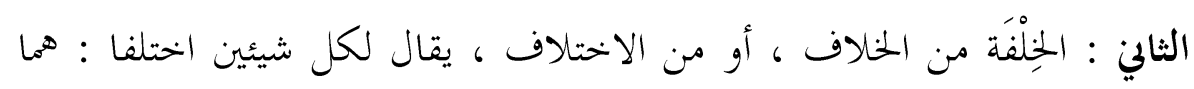

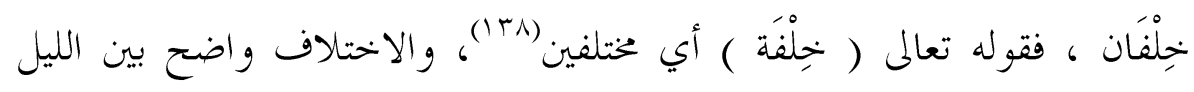

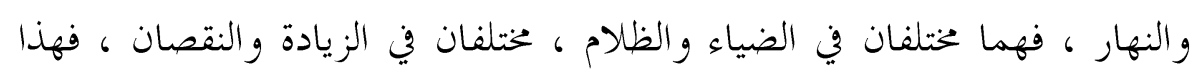


أبيض وهذا أسود ، وهذا طويل وهذا قصير ، بل هما مختلفان فيما يعم ذلك وغيره

ومعنى الآية : جعل الله تبارك وتعالى كل واحد من الليل والنهار مخالفاً صاحبه .

وقيل إن الكلام على حذف المضاف ، و والتقدير : ذوي خهلْفَة .

مه والمعنى الأول أقرب وأظهر وأقوى ، و الله أعلم .

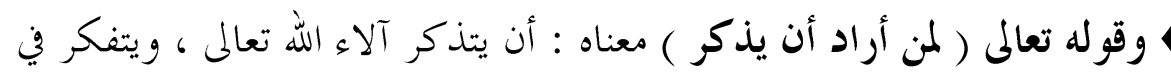

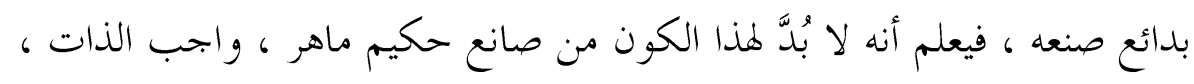

رحيم بالعباد ، فإن الناظر في اختلاف الليل والنهار ، المتدبر في انتقالهما وتغيرهما

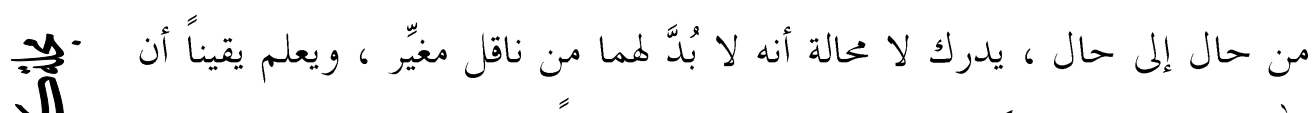
الله تعالى - وهو الحكيم الخبير - لم يخلق ذلك عبثاً ، فيستدل بذلك على عظيم

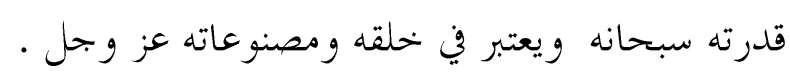

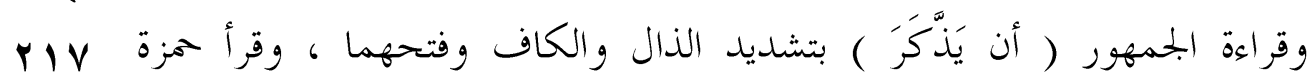

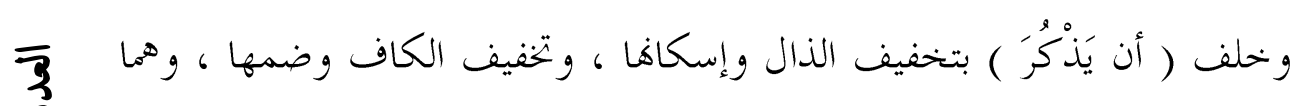

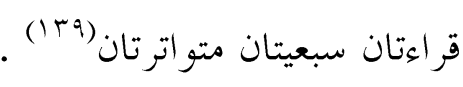
و المعنى على القراءة الأولى من التذكر ، .بمعنى الاتعاظ والاعتبار ، وعلى القراءة

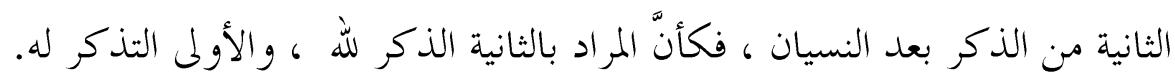

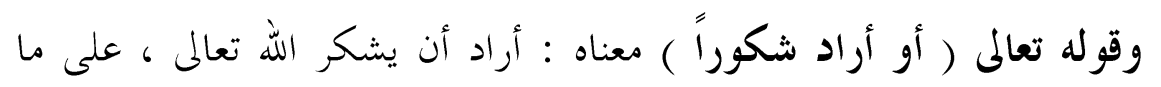

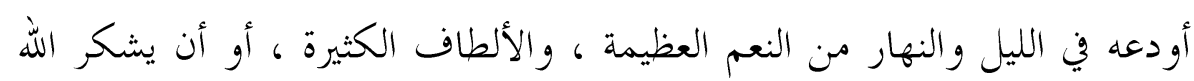
تعالى فيهما على كافة إفضاله وإنعامه .

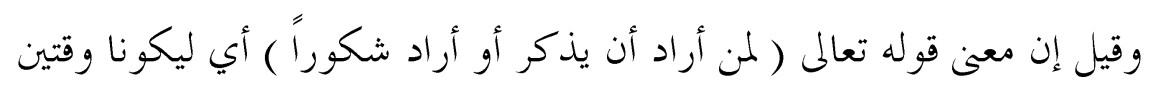

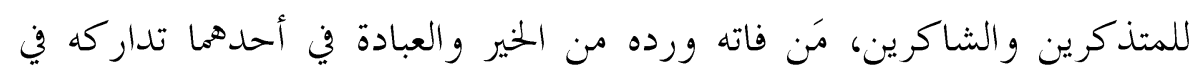

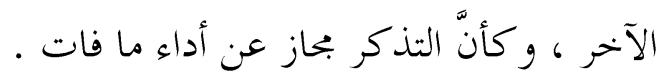




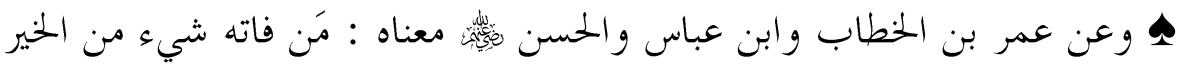

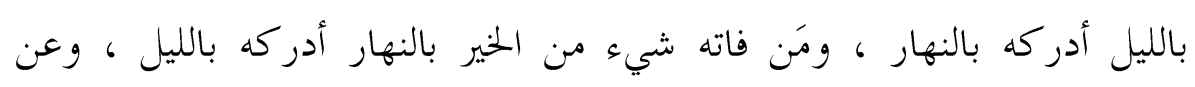

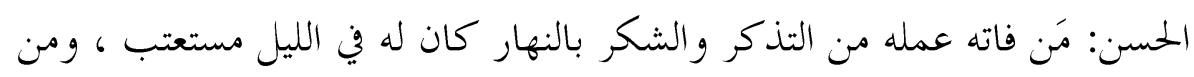

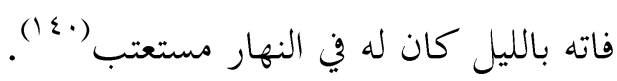

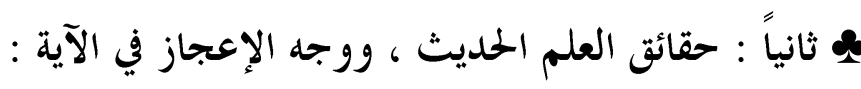

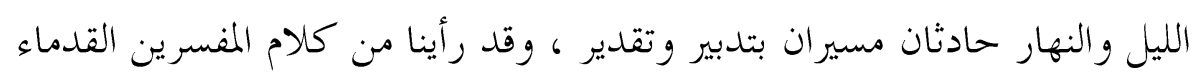

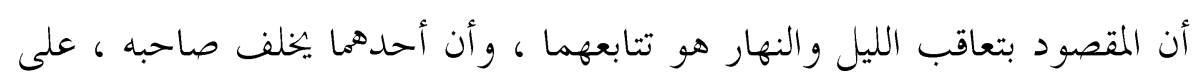

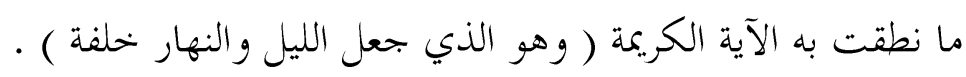

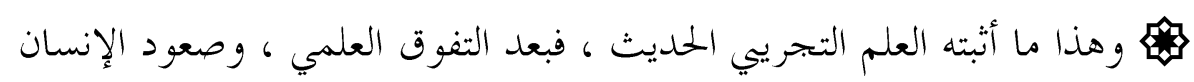

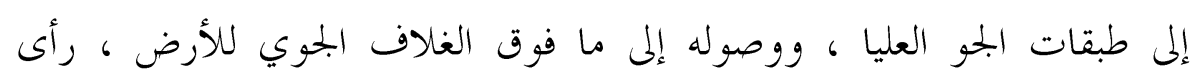

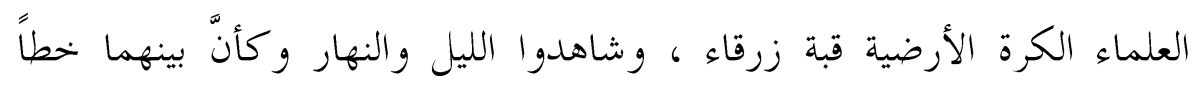

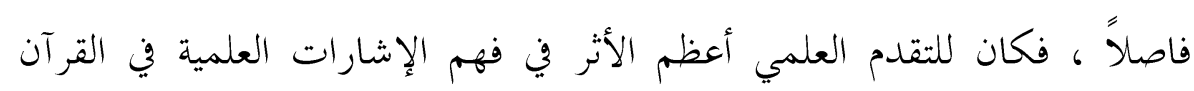

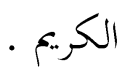

ه وإذا كان تعاقب الليل والنهار حقيقة علمية ، فإن هذا التعاقب مرتبط بحقيقة

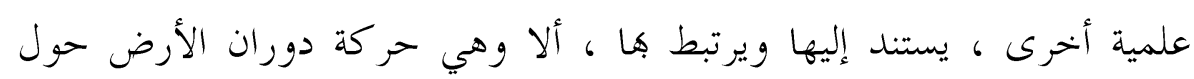

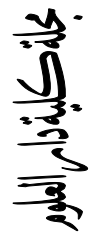

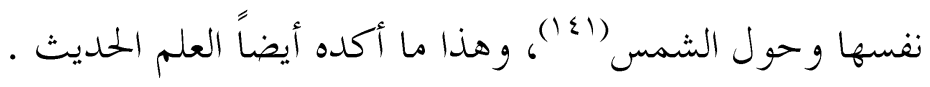

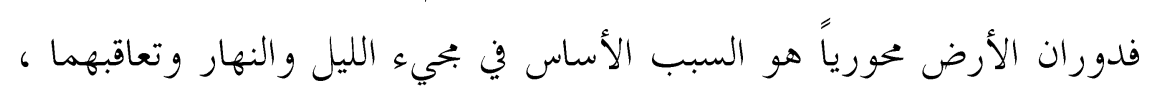

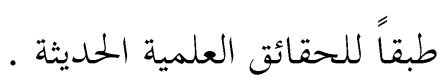

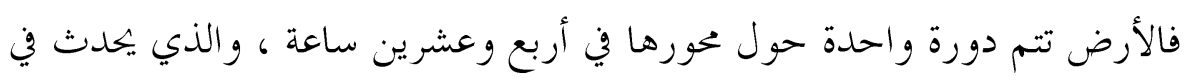

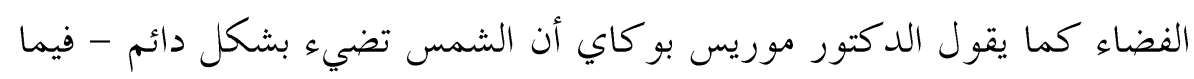

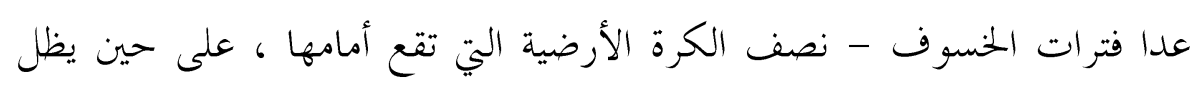

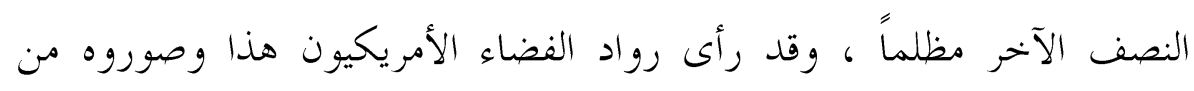

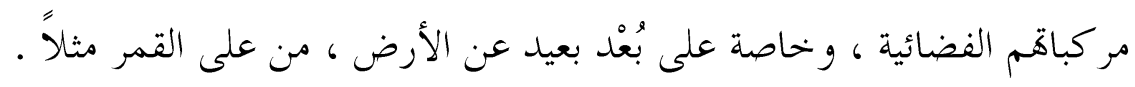
Y) 


\section{الإعجاز العلمي في سورة الفرقان}

و بدوران الأرض حول نفسها - على حين تظل الإضاءة ثابتة - فإن المنطقة المضاءة منها - وهي على شكل نصف كروي - تؤدي في أربع وعشرين ساعة

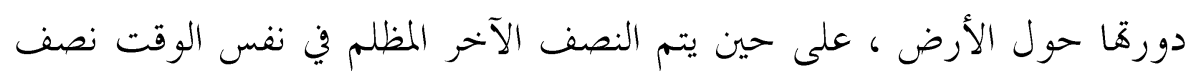
الرحلة .

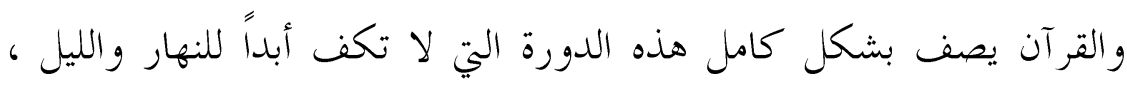
وهي اليوم يسيرة على الإدراك الإنساني ، فنحن نملك اليوم خحبرة فكرية عن ثبوت

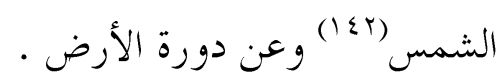

هذه العملية الدائمة في التكور مع الولوج المستمر لقطاع في آخر ، يعبر القرآن

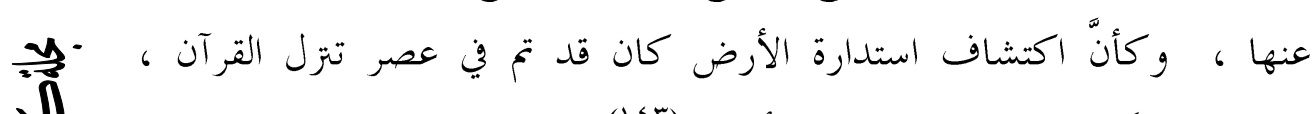

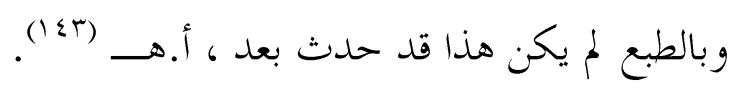

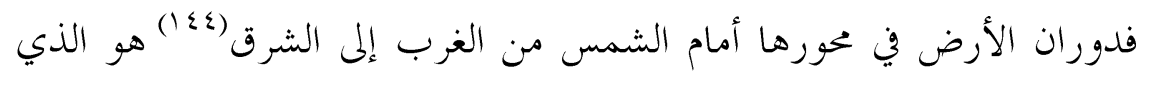

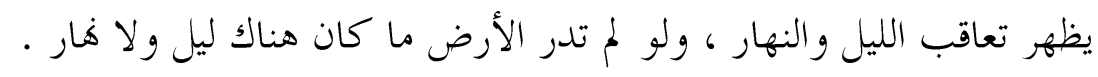

ص والخلاصة أن النهار هو ذلك الوقت الذي تتجلى فيه الشمس على نصف الكرة الأرضية فتضيئه بنورها ، و الليل هو ذلك الوقت المظلم الذي يغشي جانياً

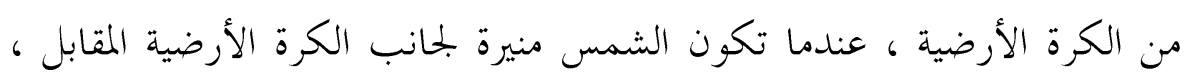
فنصف الكرة الأرضية المواجه للشمس يكون فيه نور النهار ، ونصفها الآخر

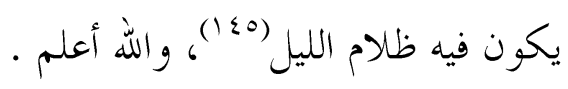
مُ و وجـــه الإعجاز في الآية الكريمة :

يتجلى من الآية الكريمة وجه آخر من أوجه الإعجاز العلمي في القرآن الكريم ،

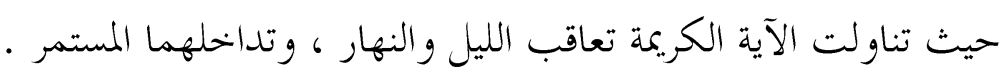

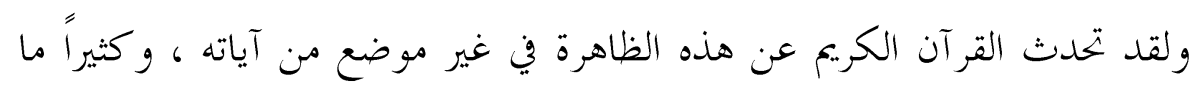

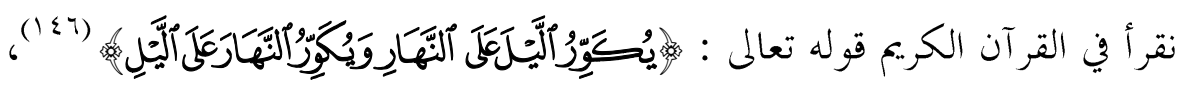

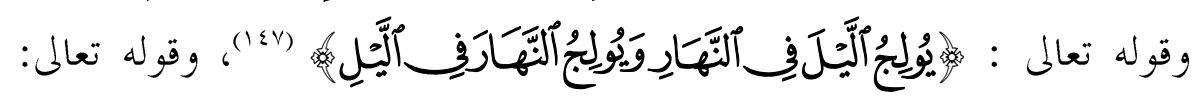




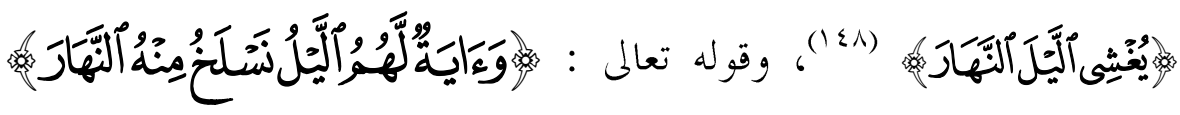

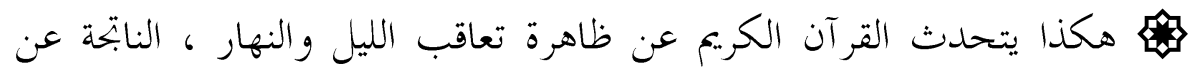

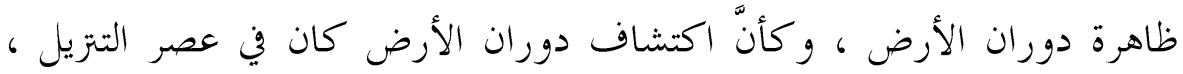
و بالطبع لم يكن هذا قد حدث بعد الارض ، وكان اكتيأ

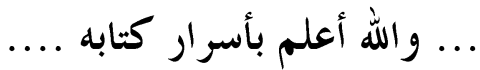

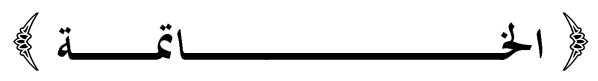

الحمد لله ، والصلاة والسلام على رسول الله ، محمد بن عبد الله ، وعلى آله وصحبه

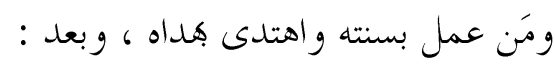

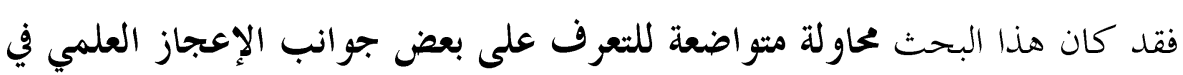

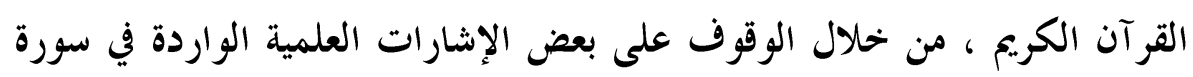

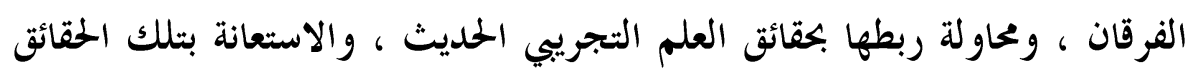

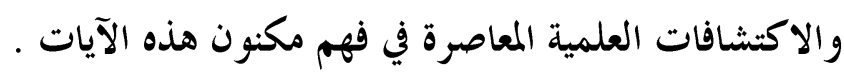

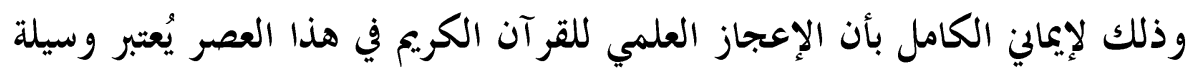

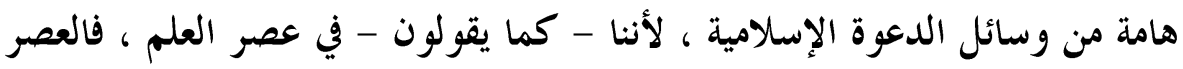
热 rr.

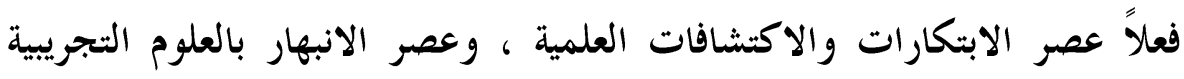

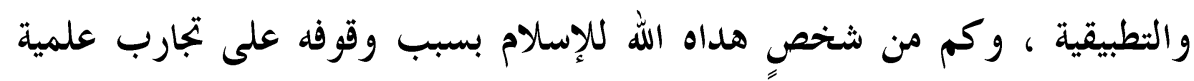

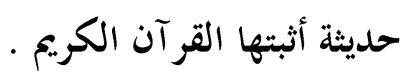

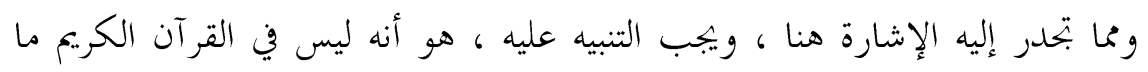

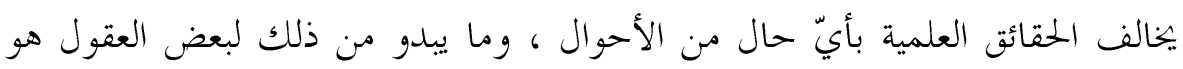

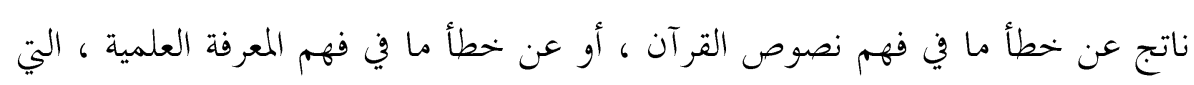

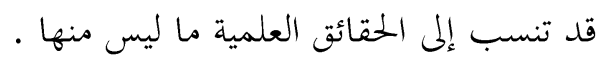
واللة من وراء القصد لئد 


\section{镸}

1- القر آن الكريم ، كلام رب العالمين ، برواية حفص عن عاصم .

Y- الإتقان في علون القر آن ، للسيوطي.

ب- الإعجاز العلمي في الإسلام ، لحمد كامل عبد الصمد .

ع- الإعجاز العلمي في القر آن د / زغلول النجار .

ه- الإعجاز العلمي في القرآن ، لممد سامي محمد علي .

ج- تفسير البيضاوي - (1)

-V

$\frac{\sqrt{3}}{5}$

م- البرهان في علوم القرآن ، للزر كشي •

9- تفسير القر آن العظيم ، للحافظ ابن كثير .

• 1- التفسير العلمي للقر آن في الميزان ، لأحمد عمر أبو حجر .

rYI

1 1- التفسير الكبير ، أو مفاتيح الغيب ، للإمام الرازي .

$\overline{3}$
$:$

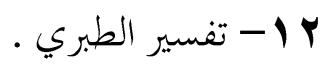

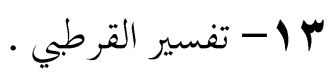

ع ا- حاشية الشهاب على تفسير البيضاوي ، للشهاب الخفاجي .

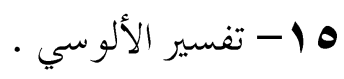

7 ا 1 ز زاد الدعاة من العلم و الآيات ، لممود البرشة .

· 1V

11 ا- فتح القدير ، للشو كاني .

9 1 - القرآن الكريم و التوراة والإبجيل والعلم ، دراسة الكتب المقدسة في ضوء

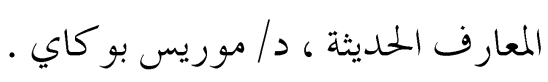

• Y- قضية الإعجاز العلمي للقر آن ، د / زغلول النجار • 
ا Y- تفسير الكشاف ، للزخشري .

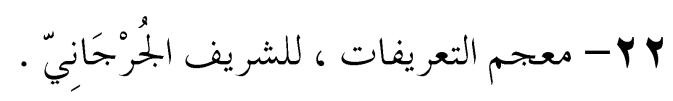
بr - مناهل العرفان في علوم القر آن ، للزرقاني. צ Y- نماذج من الإعجاز العلمي في القرآن والسنة ، إعداد نخبة من أساتذة الهيئة

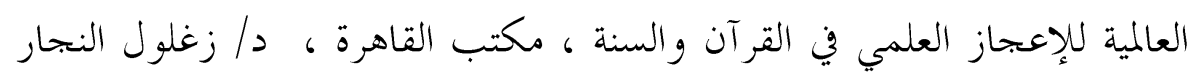

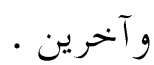
إلى غير ذلك من المراجع والمصادر المذكورة في ثنايا البحث

الهوامش الإحالات :

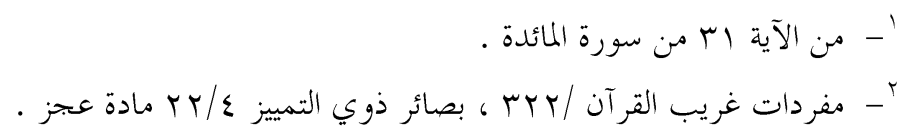

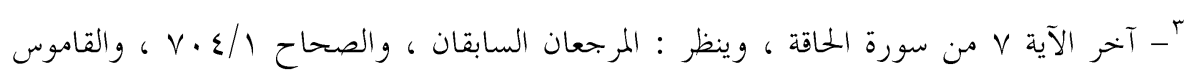

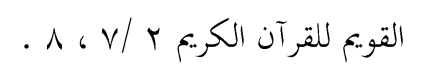

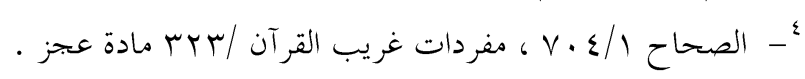

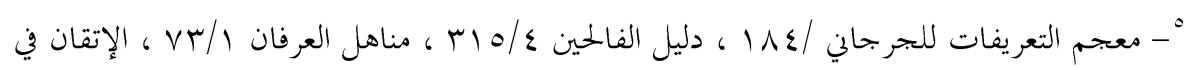

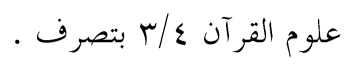

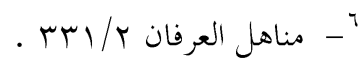
$\frac{\sqrt{3}}{3}$ YYY

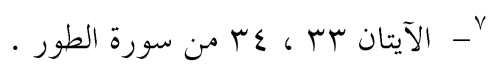

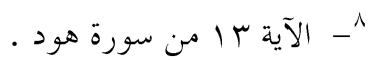

$$
\begin{aligned}
& \text { ج- الآية مب من سورة يونس . }
\end{aligned}
$$

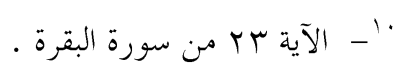

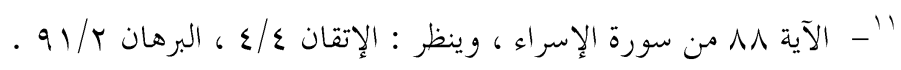

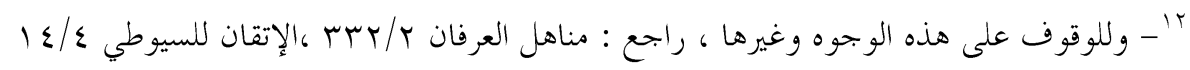
البرهان للزر كشي ول/ و

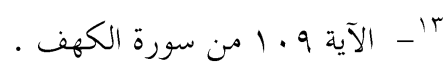

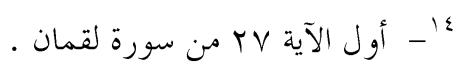




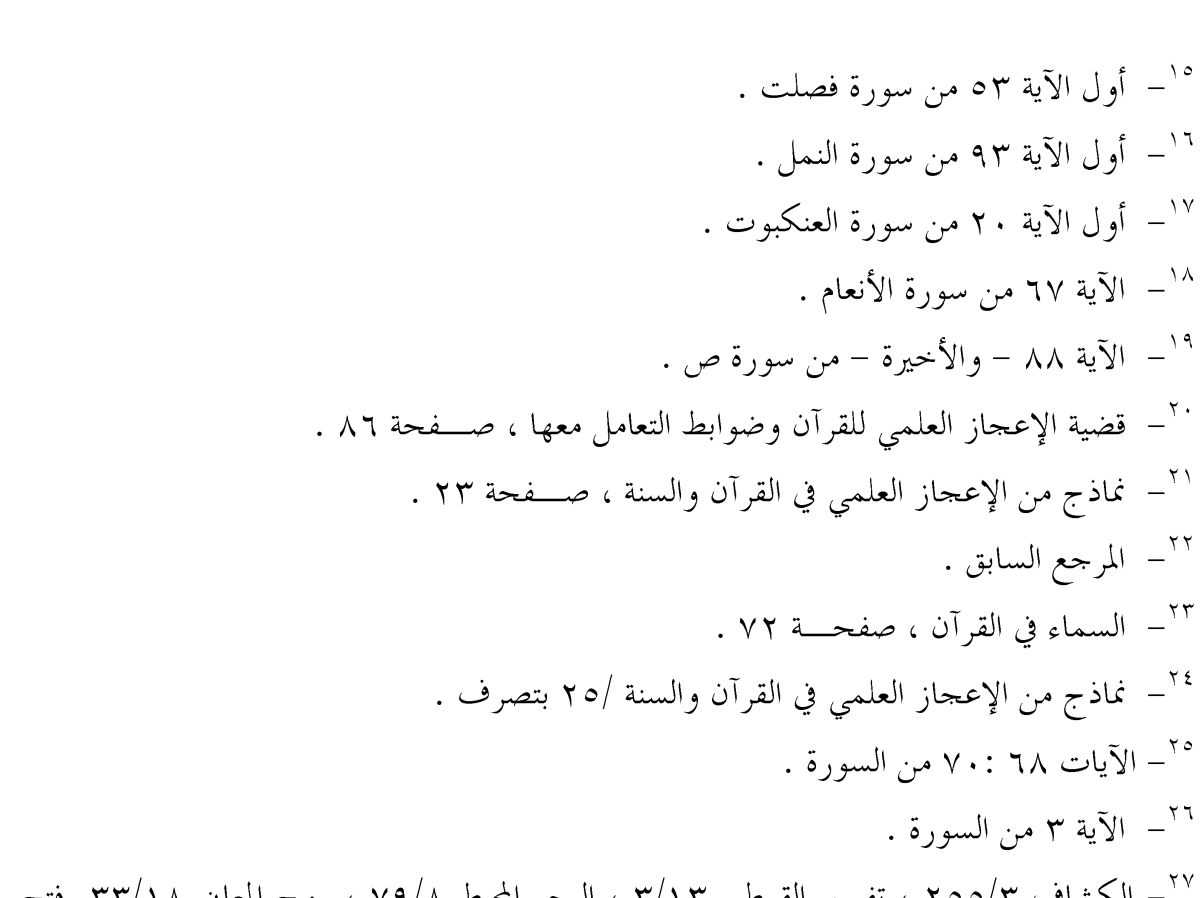

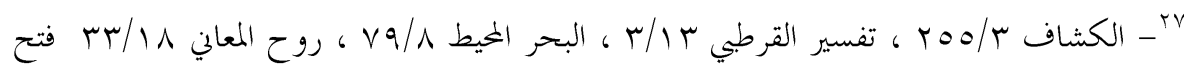

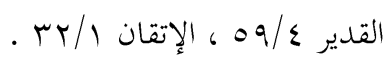

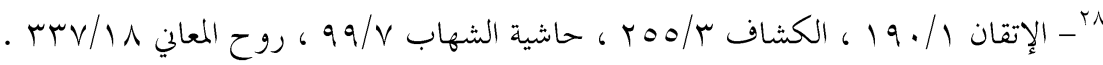

$$
\text { . }
$$

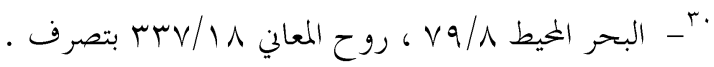

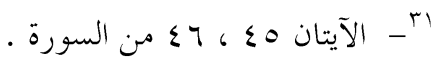

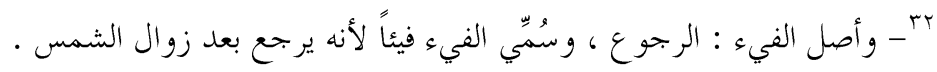

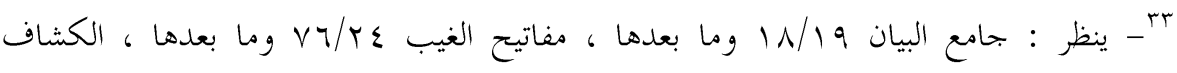

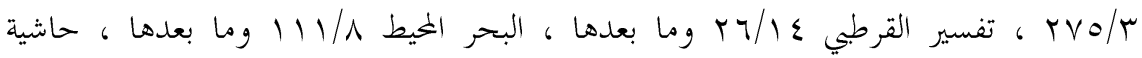

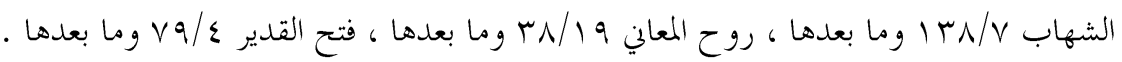

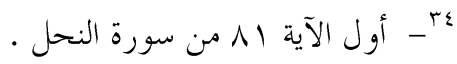

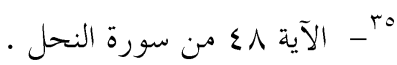

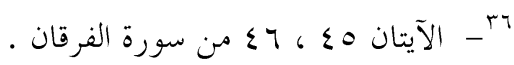

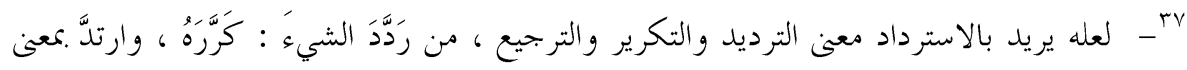

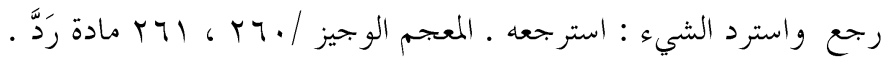




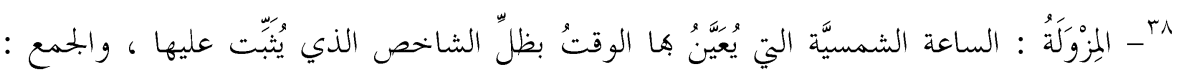

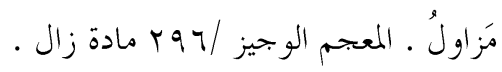

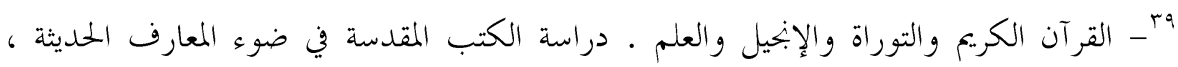

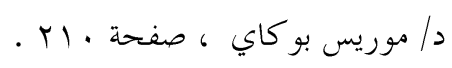

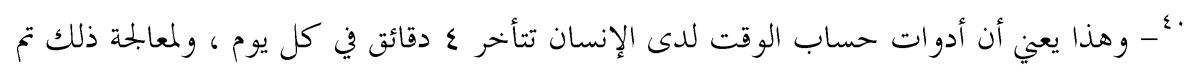

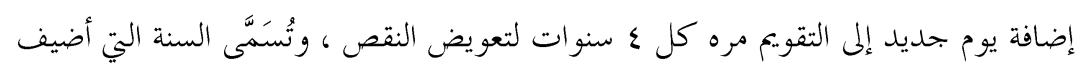

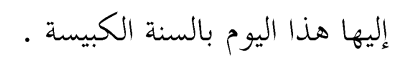

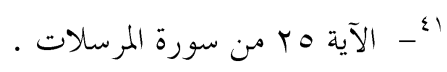

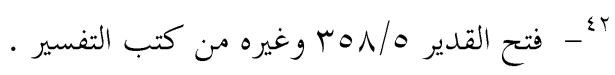
.

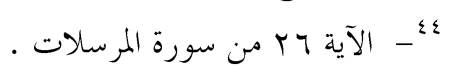

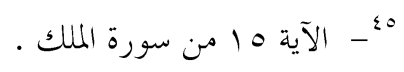

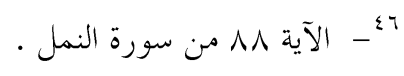

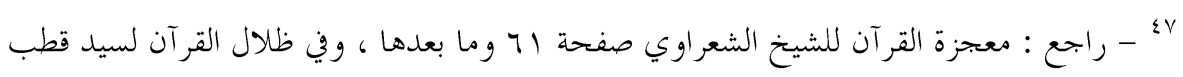
. rTrV/T، rot9/0 هُ

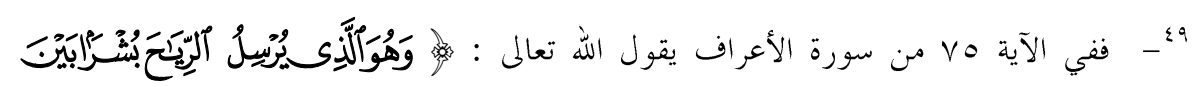

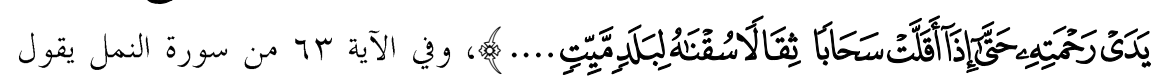

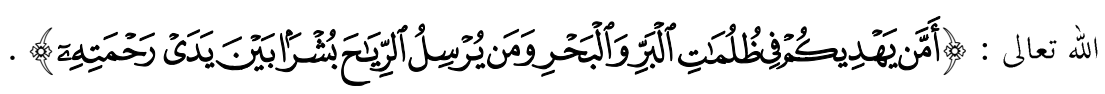

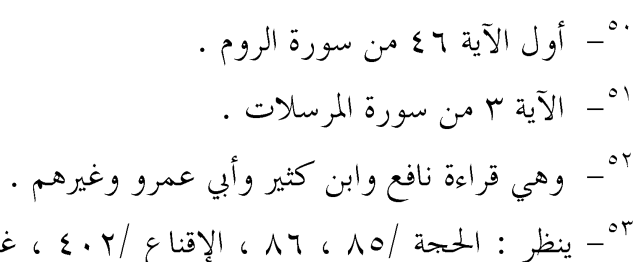

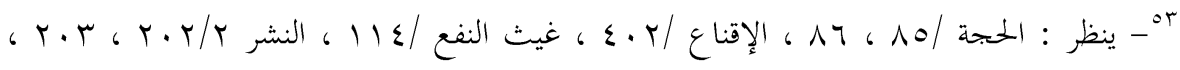

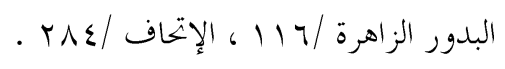

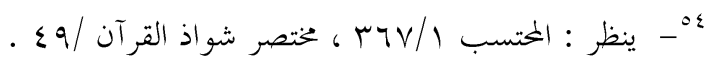

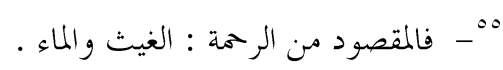

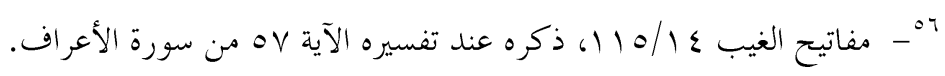




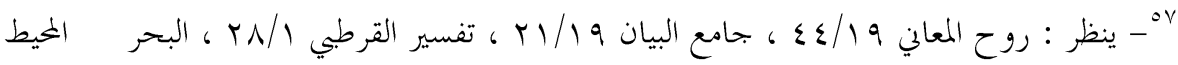

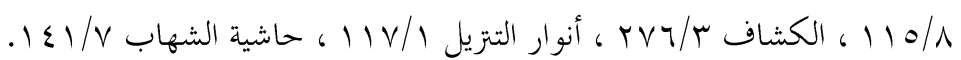

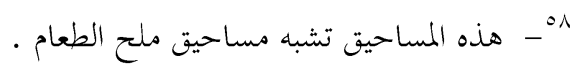

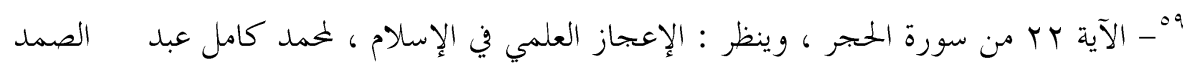

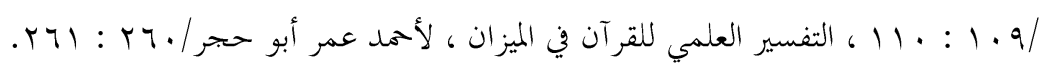

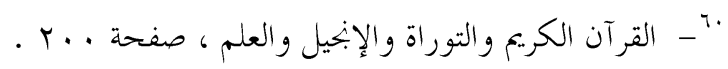

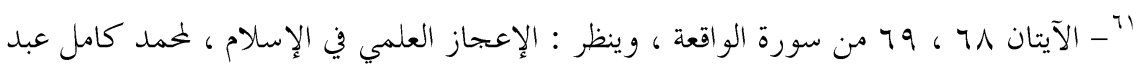

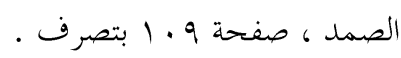
·

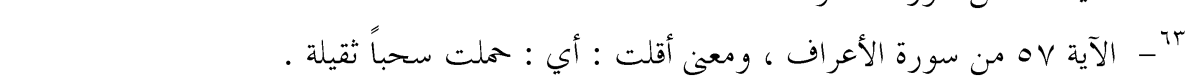

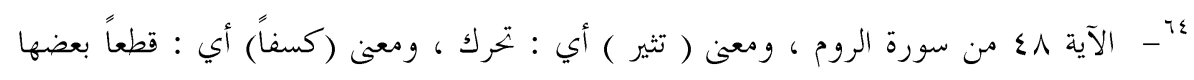

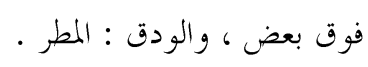
ro

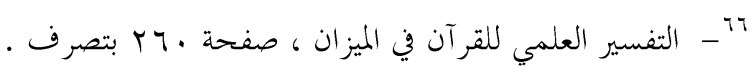

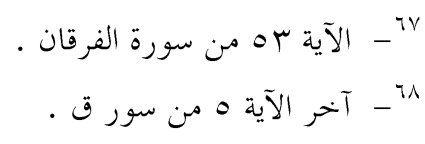

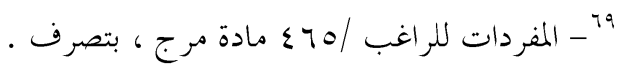

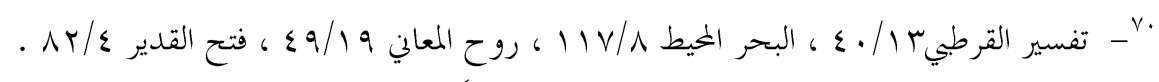

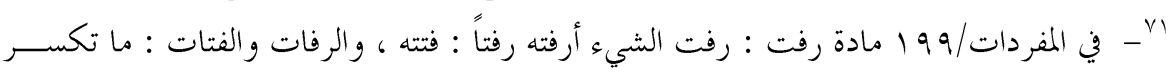

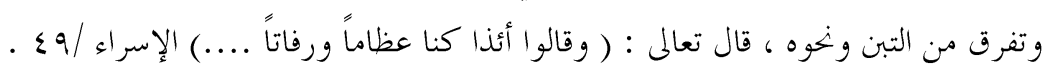

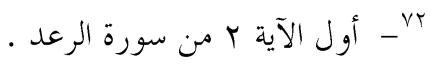

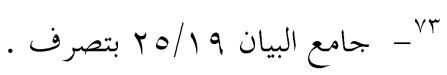

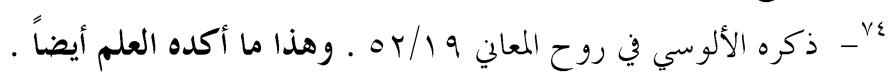

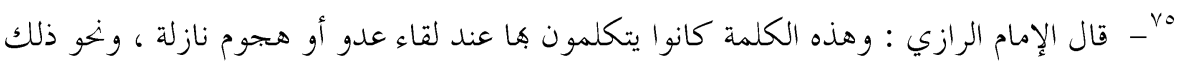

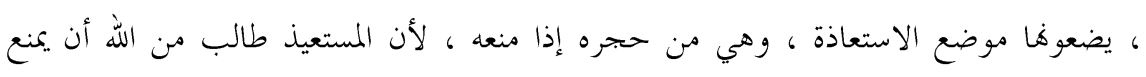

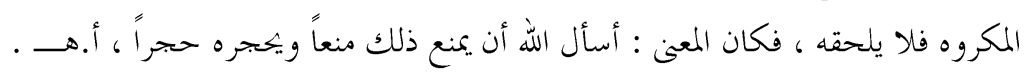


مفاتيح الغيب ع NV/Y ، ذكره عن تفسير قوله تعالى : ( يوم يرون الملائكة لا بشرى يومئذ

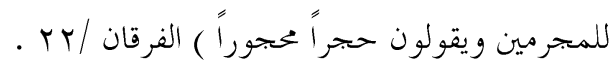
דr

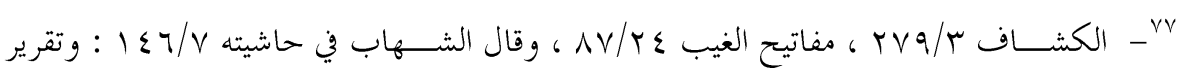

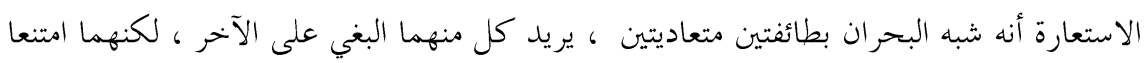

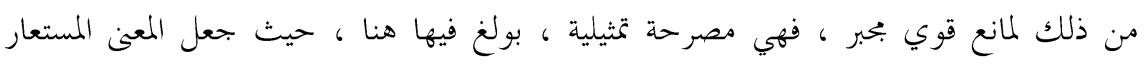

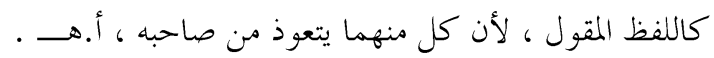
ه

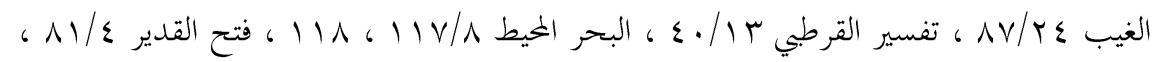

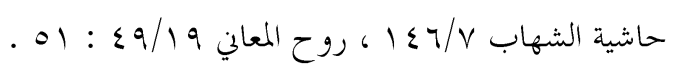

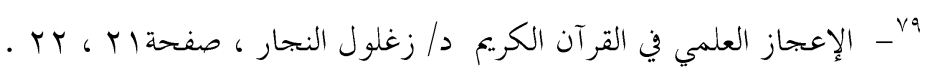

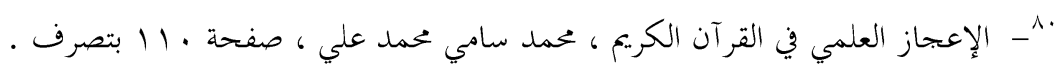

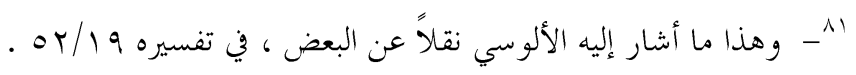

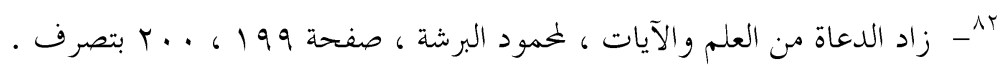

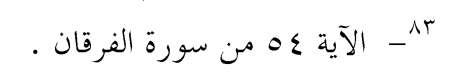

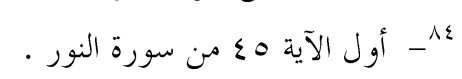
.

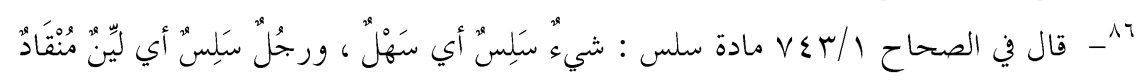

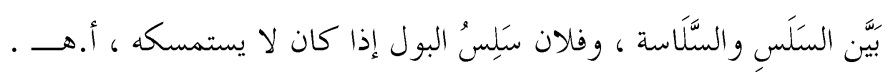

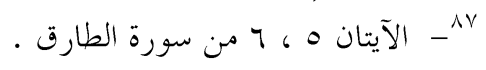

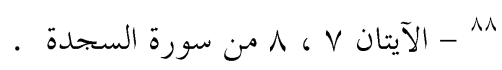

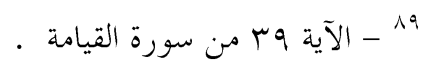

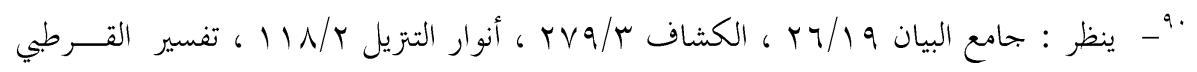

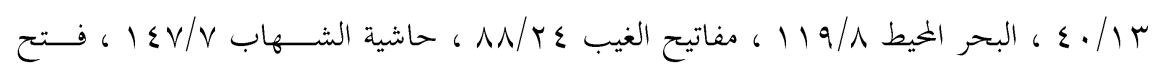

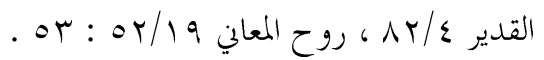

$$
\begin{aligned}
& \text { 1" - من الآية .ب من سورة الأنبياء. }
\end{aligned}
$$

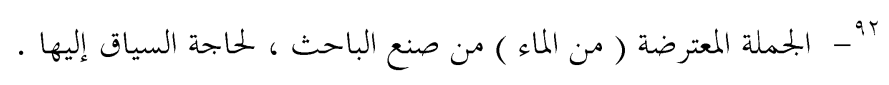




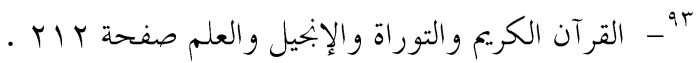

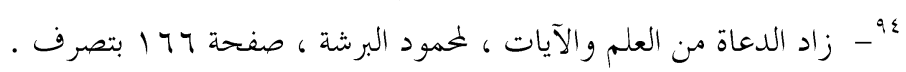

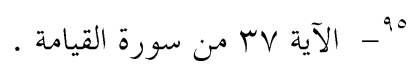

ب9 - الآية مه من سورة الواقعة . من سورة القيامة.

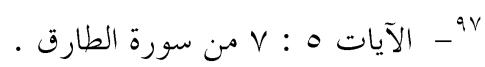

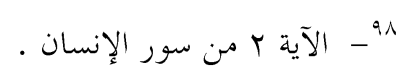
99-9 الآية ع الاية من سورة المؤمنون . الإنسان.

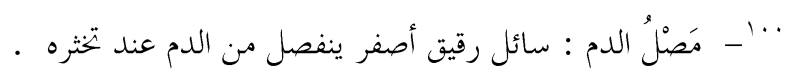

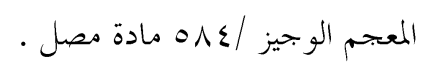

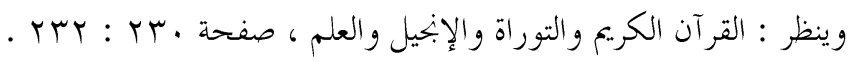

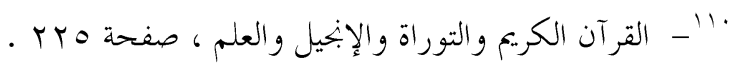

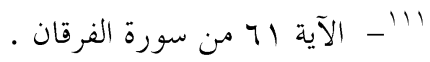

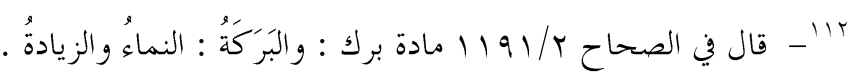
r'

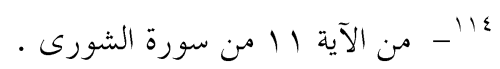




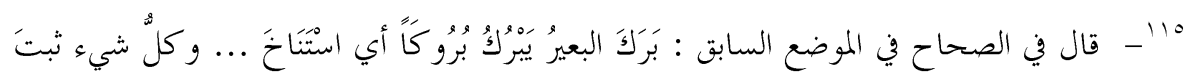

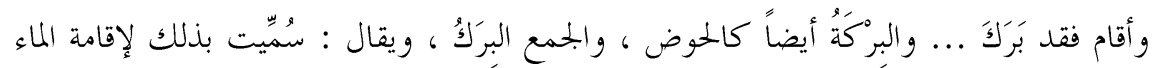

فيها .

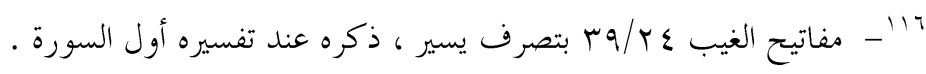

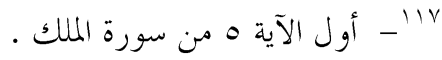

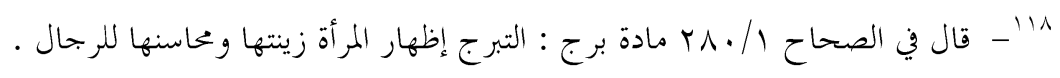

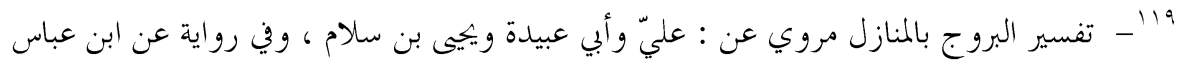

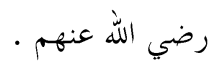

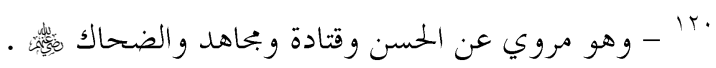
.

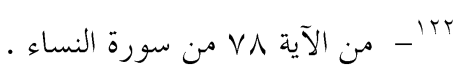

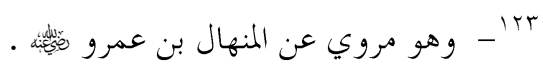

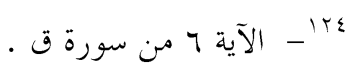

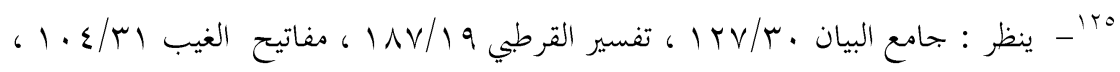

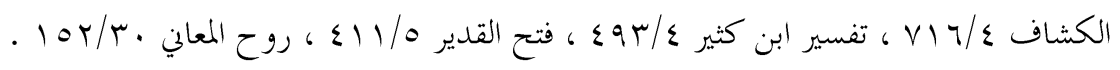
ل

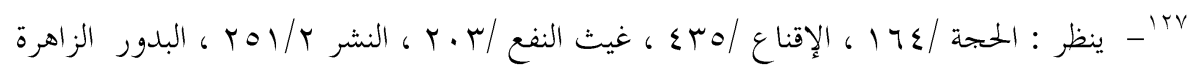

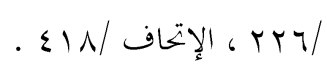
ل

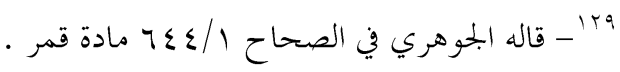

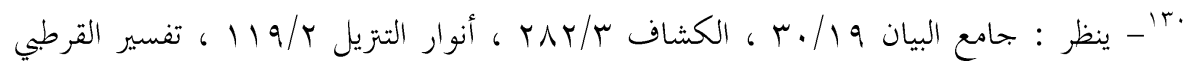

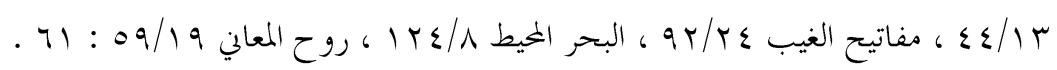

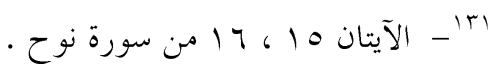

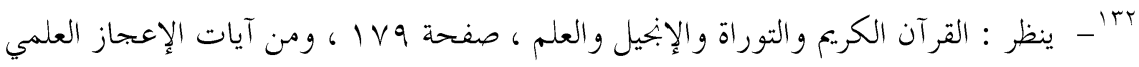

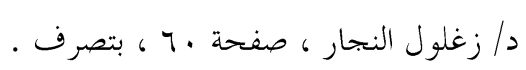

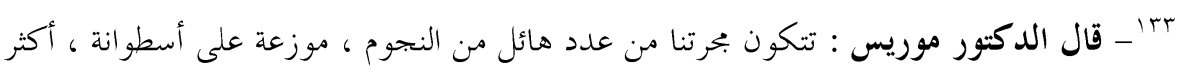

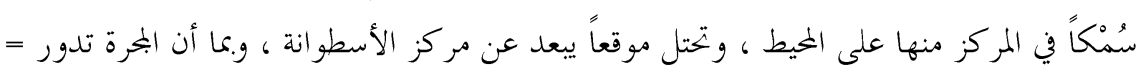


= حول نغسها - و كان محورها مركزها - فإن ناتج ذلك هو أن الشمس تدور حول نفس هذا المركز ، على حسب مدار دائري .

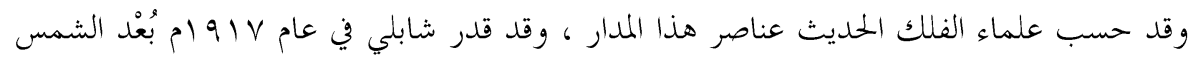

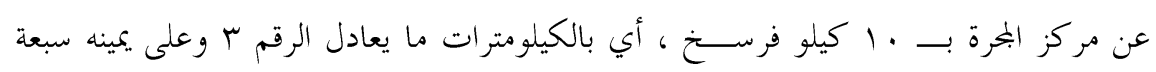
عشر صفراً .

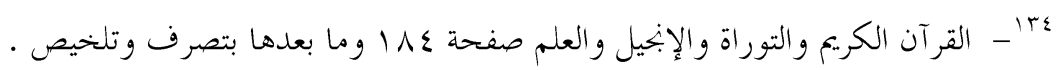

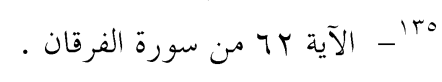

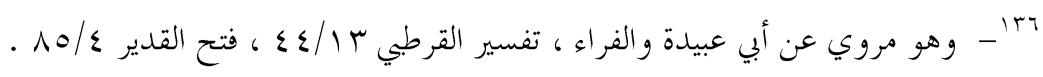

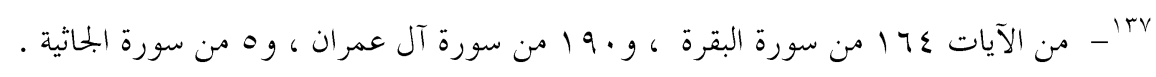

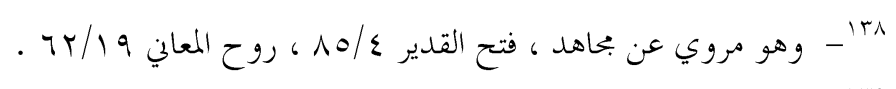

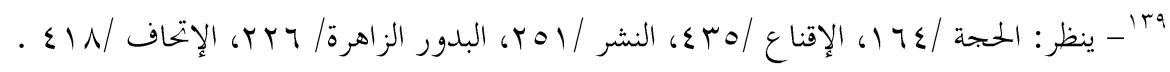

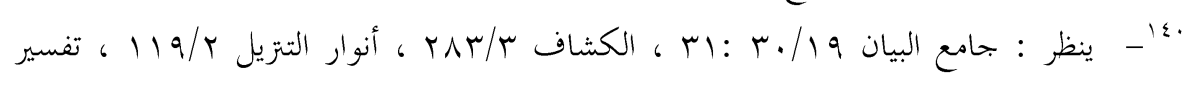

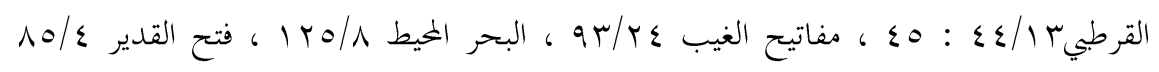

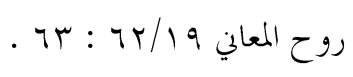

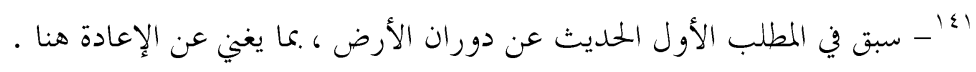

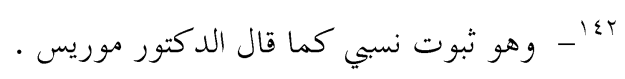

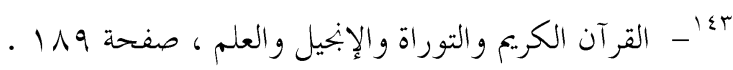

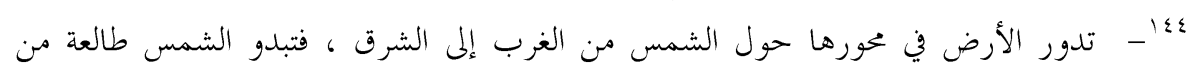

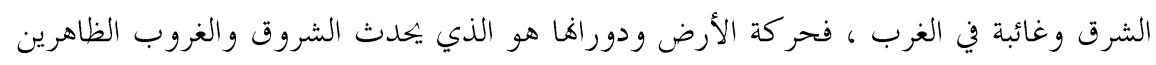

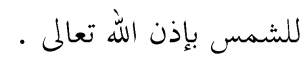

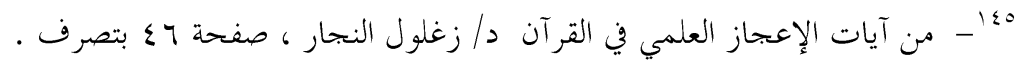

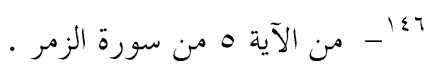

Y\&

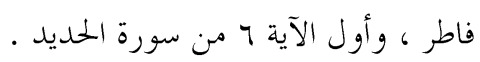

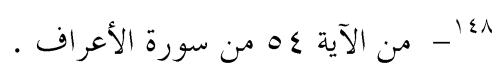

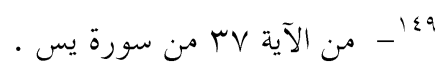




\begin{tabular}{|c|c|c|c|}
\hline الصفحة & موضوع البحث & اسه الباحث & مر \\
\hline 9 & أثر الاتجاهات الفكرية في تأويل & 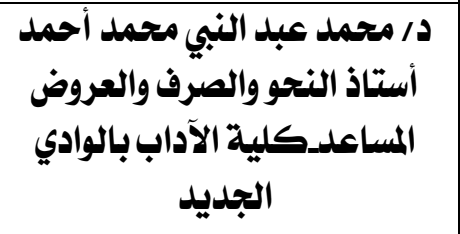 & 1 \\
\hline ro & 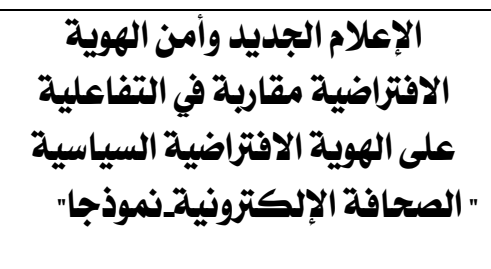 & 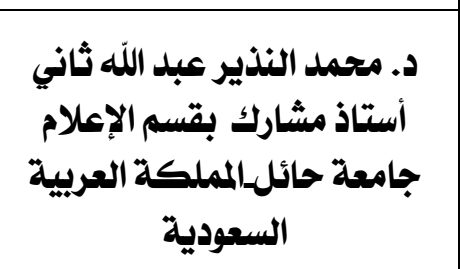 & 2 \\
\hline ar & الشعر في مواجهة الإرهاب_دراسة من الشعر السعودي & 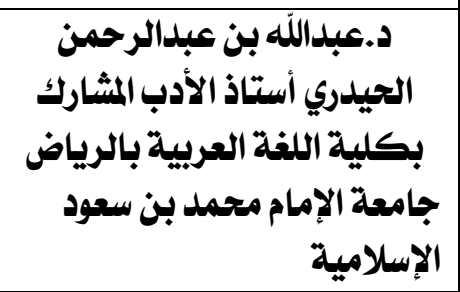 & 3 \\
\hline Irq & جمالية التوازي الدرامي في " مصير & 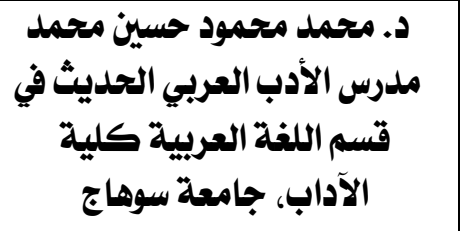 & 4 \\
\hline Iro & الإعجاز العلمي في سورة الفرقان & 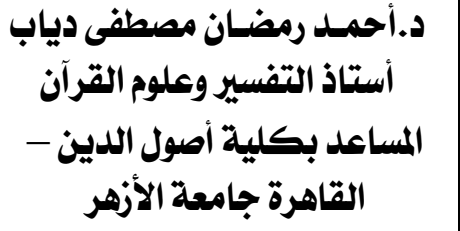 & 5 \\
\hline
\end{tabular}


رقم اليداع

$r \cdot 11 / 11001$

التزقيم الدولي

(ISSN PrOT - 9ATY) 